Universidade de Brasília

Instituto de Letras

Departamento de Teoria Literária e Literaturas

Programa de Pós-graduação em Literatura

\title{
A INFÂNCIA NOS ROMANCES AFRO-BRASILEIROS DE CONCEIÇÃO EVARISTO
}

Maria Aparecida Cruz de Oliveira

Orientador: Anderson Luís Nunes da Mata

Brasília - DF 
Maria Aparecida Cruz de Oliveira

\section{A INFÂNCIA NOS ROMANCES AFRO-BRASILEIROS DE CONCEIÇÃO EVARISTO}

Dissertação apresentada ao Programa de Pós-Graduação em Literatura do Departamento de Teoria Literária e Literaturas - TEL do Instituto de Letras da Universidade de Brasília UnB como requisito parcial para a obtenção do título de Mestre.

Área de concentração: Literatura Linha de Pesquisa: Representação Literária

Orientador: Prof. Dr. Anderson Luís Nunes da Mata

Brasília - DF 


\title{
A INFÂNCIA NOS ROMANCES AFRO-BRASILEIROS DE CONCEIÇÃO EVARISTO
}

\author{
Banca Examinadora
}

Prof. Dr. Anderson Luís Nunes da Mata - TEL/UnB

(Orientador e Presidente da Banca)

Fernanda Alencar Pereira

(Membro externo)

Cintia Schwantes

(Membro interno)

Virgínia Maria Vasconcelos Leal

(Membro suplente) 
Dedico esta dissertação a todas as crianças negras brasileiras e a todos os brasileiros negros que se identificam de algum modo com as crianças da literatura afro-brasileira (Especial aos sobrinhos Raquel, Felipe, Henrique, Eduardo e Lara). 


\section{Agradecimentos}

Iniciar um trabalho acadêmico é sempre um grande desafio. Nunca nos constituímos enquanto sujeitos sem a interação com o outro e o inevitável diálogo que proporciona tantos conhecimentos e possibilita o necessário crescimento. Dentro desse espaço de devaneio, dedico-me a rememorar pessoas que de alguma forma contribuíram para o meu conhecimento e que se tornaram peças de um quebra cabeça que agora se finda, ou não. A simples menção, as palavras mais simples, não diz o todo pretendido, mas a palavra mais singela é, às vezes, a chave mais segura para desenhar um novo traçado na corrente da vida.

O principiar desse trabalho me deu o prazer de compartilhar conhecimentos e experiências com uma pessoa fundamental para a conquista que se vislumbra nesse momento. É exatamente por esse motivo, e tantos outros que deixo de mencionar aqui, que começo esses agradecimentos com a pessoa do professor Anderson Luís Nunes da Mata, orientador deste trabalho, que sem abrir mão de exigências, sempre soube me ofertar liberdade para pensar de forma autônoma; pela qualidade das observações e do olhar crítico.

Também é motivo de menção a figura da minha querida estrela Dalva Martins, amiga e companheira dos mais fundamentais momentos, pessoa que desde os primeiros contatos iluminou minha vida com amor gratuito.

Ao grande amigo, o pesquisador Bruno Angeli Faez, pelas leituras compartilhadas.

Dentro do diálogo vindouro que integra a Pós-Graduação seria imprescindível trazer nomes de professores do Departamento de Teoria Literária e Literaturas pelos ensinamentos e apoio proporcionados ao longo do meu trajeto de mestranda. Minhas palavras de agradecimento ficam aqui registradas para os mestres Edvaldo Bérgamo, Cíntia Schwantes, Regina Dalcastagnè, Virgínia Leal e Ana Cláudia da Silva.

O limiar da pesquisa acadêmica, para além de assistir as aulas e escrever a dissertação, possui outro requisito básico para a formação do pesquisador, que é a pesquisa. Essa não consiste em um diálogo solitário com o livro, mas exige a presença de vários outros atores em diálogo em torno da mesma questão. É exatamente por causa dessa presença indispensável que deixo meus agradecimentos especiais ao Grupo de Estudos em Literatura Brasileira Contemporânea (GELBC), por me oportunizar o debate necessário para a construção acadêmica. 
É, também, por entender o desafio que consiste a coordenação de um programa com a magnitude do nosso que abro espaço para agradecer o coordenador desse programa, o professor Piero Eyben, pelo trabalho realizado, em parceria com a professora Sylvia Cyntrão, para o crescimento da Pós-Graduação em Literatura da nossa Universidade.

Assim como a interação com a Academia é imprescindível para a formação do sujeito, anterior a essa existe uma entidade que é considerada a primeira formadora da pessoa humana: a família. É acreditando nessas palavras que guardo os mais sinceros agradecimentos a minha família, a começar pelo meu irmão José Flávio Cruz de Oliveira (in memoriam) que me incentivou a leitura e pelas histórias compartilhadas. Às minhas irmãs Flávia, Angélica e Fabrícia pelo apoio, carinho e amizade. À minha mãe, Irailde Cruz de Oliveira por me falar da importância dos livros. Ao meu pai, José Pereira de Oliveira pelo apoio de sempre.

O mundo acadêmico também integra outro grupo que se assemelha a uma família em prol dos mesmos objetivos, que são os colegas que muito nos acompanham nas aulas e em outras vias de conhecimento. Nesse sentido, inicio agradecendo as figuras da Luciana Teixeira e Clara Bomfim, primeiras pessoas que me foram apresentadas por essa Universidade. Ao companheiro e amigo Lemuel Gandara, por compartilhar uma vida, conhecimento e carinho. À amada Elizabete Barros pelo companheirismo, amizade e apoio acadêmico. À generosa Kelly Vyanna. Ao Douglas Rodrigues pelo riso amigo e os diálogos traçados. À prodigiosa Ana Clara Medeiros pelo carinho e atenção. À presença unânime de Rosa Alda, amiga de tantos diálogos e à querida Geise Enders.

E, por fim, ao Conselho Nacional de Desenvolvimento Científico e Tecnológico - CNPq, pelo apoio financeiro para a realização desta pesquisa. 
"Muleque, muleque quem te deu este beiço assim tão grandão?

Teus cabelos de pimenta do reino? Teu nariz essa coisa achatada?

Muleque, muleque quem te fez assim?

Eu penso, muleque que foi o amor..."

Canto Negro

Solano Trindade 


\section{RESUMO}

O objetivo dessa dissertação foi investigar como ocorre a representação da infância de crianças negras nos romances afro-brasileiros, Ponciá Vicêncio (2003) e Becos da Memória (2006) de Conceição Evaristo. A visão investigativa partiu do pressuposto de que as crianças negras raramente são figuradas na literatura brasileira, ocupando um lugar claramente periférico na tradição literária. Entretanto, constatou-se que essas crianças ganham visibilidade e representação legitimada/plausível e autorizada nas criações literárias dos romances afro-brasileiro-contemporâneos de Conceição Evaristo. Por seu caráter político consideramos que essas narrativas surgem como tentativas de autorrepresentação da infância por parte dos escritores negros, de modo que o projeto estético e político da presente literatura vem exatamente ao encontro desses ideais. As crianças negras narradas na literatura afro-brasileira de Conceição Evaristo são criadas como atores históricos capazes de reagir, engendrar tensões e criar conflitos para momentos de escape, como forma de resistência às opressões vivenciadas. Logo, o objetivo foi examinar a figuração do espaço social da infância nesses romances, explicitando o modo como a autora utiliza a estetização da memória para colocar a criança negra em cena e apresentar o infantil, isso sem perder de vista que a infância aqui discutida parte da premissa de uma construção histórica, cultural e passível de variações sociais.

Palavras-chave: Representação. literatura afro-brasileira. infância. Ponciá Vicêncio. Becos da Memória. Conceição Evaristo. 


\begin{abstract}
This paper's goal is to investigate how the childhood representation of black children happens in the afro-Brazilian novels, Ponciá Vicêncio (2003) and Becos da Memória (2006) both by Conceição Evaristo. Our investigative view came from the presupposition that black children rarely appear at Brazilian literature, clearly occupying a peripheral place at the literary tradition. However, it's been found that these children gain visibility and a plausible/legitimate representation and authorized in the contemporary-afro-Brazilian literary works at Conceição Evaristo's novels. By its political character we consider that these stories appear as attempts at selfrepresentation of the childhood by these black writers, in a way that the political and aesthetic project of the current literature comes to meet those ideals perfectly. The black children narrated in Conceição Evaristo's afro-Brazilian literature are made as historical actors capable of reacting, engendering tensions and raising conflicts for escape moments, as a way of resistance against the oppressions lived by them. Therefore, the goal is to examine the figuration of the childhood's social space in these novels, highlighting the way that the author uses the memory's aesthetization to put the black child on stage and present the childish, that without losing sight the childhood here discussed comes from the premise of a historical, cultural building susceptible to social variations.
\end{abstract}

Keywords: Representation. afro-Brazilian literature. Childhood. Ponciá Vicêncio, Becos da Memória and Conceição Evaristo. 


\section{Sumário}

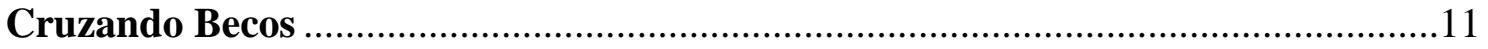

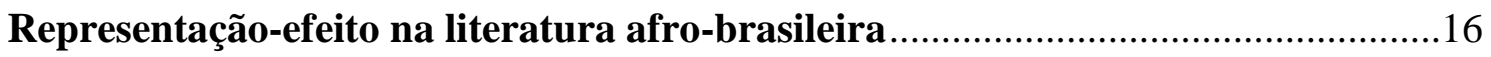

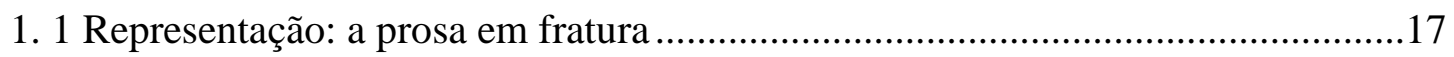

1.2 Representação: Uma questão de percepção ………………................................26

1.3 Representação: Ponciá Vicêncio e Becos da Memória ............................................31

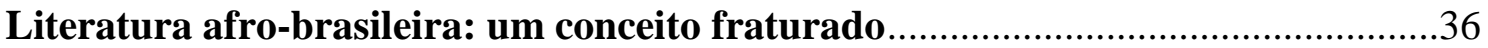

2.1 Literatura afro-brasileira: particularização de uma escrita ...................................37

2.2 “A arte não cabe em definições": literatura negra, negro-brasileira ou afro-

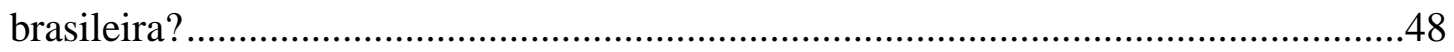

2.3 Tendências e perspectivas fraturadas: "O eu-sujeito a criar um texto" ..................53

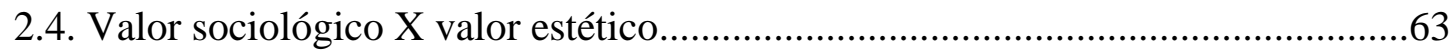

A negociação da infância nos romances de Conceição Evaristo ..............................68

3.1 A criança negra na Literatura Afro-brasileira ..................................................69

3.2 Memória e esperança: imagens da infância em Ponciá Vicêncio e Becos da

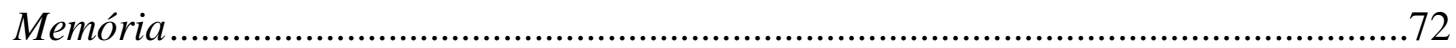

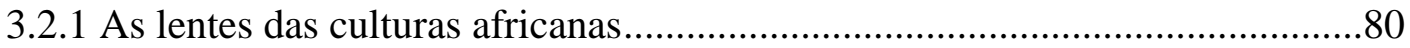

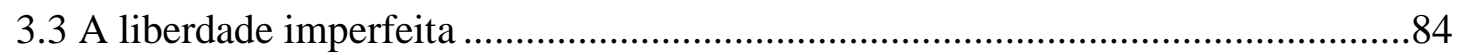

$3.4 \mathrm{O}$ tempo e espaço social das crianças negras...................................................... 87

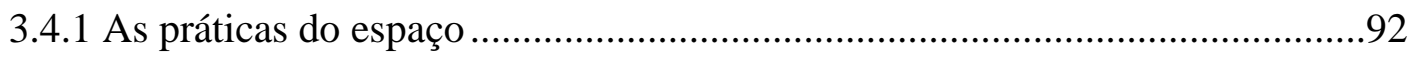

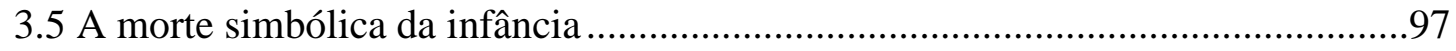

3.5.1 O retorno a infans: a alegoria da origem, retorno à origem/ao início da fala100

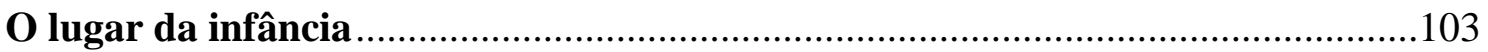

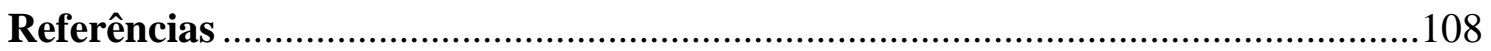


"Agarrei o nascer do sol, Fiz parceria com o rouxinol e pari,

Suavemente, a vida com um grito De liberdade"

Celi Santos

\section{Cruzando Becos}


A narrativa apenas se principiou, mas já traz a forte sentença: "Que ideia faria de si essa criança que sempre era alvo de ignorantes? Não, apenas era considerada desajeitada" (PRADO, 2009, p.41). É assim que a narradora de "A infância de Daiane" de Dirce Pereira do Prado no volume 33 dos Cadernos Negros problematiza a puerícia da protagonista Daiane. Preliminarmente, a narradora preocupa-se com a formação identitária e com o que lhe é revelado acerca da menina, mas logo tenta iludir-se, arrisca amenizar a problemática como se não pudesse acreditar na sua própria visão. O fim da sentença é marcado por essa proposital invalidação das questões que envolvem as dificuldades detectadas pela narradora sobre a garota pobre, negra e órfã. Essa foi a solução encontrada por ela para resolver o problema que tanto a afligia: a insinuação de que a rejeição dos colegas de escola à menina apenas estaria relacionada com o seu "jeito desajeitado".

A base dessa última afirmação converge na denúncia de como a condição marginal da criança negra tem sido silenciada e diminuída, ou como a exclusão dessa população vem sendo mencionada como um problema menor, ou uma questão quase superada. Pensamentos como o de Gilberto Freyre (2004), o qual afirma a existência de uma "democracia racial", por exemplo, são sintomáticos, pois reafirmam a ideia romântica de que o negro brasileiro não tem problemas sociais relacionados à sua cor, uma vez que o discurso do autor está posicionado para mostrar uma harmonia híbrida e negar as complexidades existentes.

\begin{abstract}
A força, ou antes, a potencialidade da cultura brasileira parece-nos residir toda na riqueza de antagonismos equilibrados (...). Não que no brasileiro subsistam, como no anglo-americano, duas metades inimigas: a branca e a preta; o ex-senhor e o ex-escravo. De modo nenhum. Somos duas metades confraternizantes que se vêm mutuamente enriquecendo de valores e experiências diversas; quando nos completarmos num todo, não será com o sacrifício de um elemento a outro (FREYRE, 2003, p. 23 e 24).
\end{abstract}

As palavras de Freyre promovem a simulação de uma convivência pacífica, de igualdade de raça e aceitação das culturas negras no contexto brasileiro. Essa é mais uma consideração que apaga a verdade histórica dos povos negros brasileiros, em que o atraso social do negro estaria apenas associado à escravidão e nunca ao racismo.

$\mathrm{Na}$ contramão dessa ideia de "metades confraternizantes", as infâncias de crianças negras figuradas em A infância de Daiane, em Ponciá Vicêncio e em Becos da Memória tecem uma denúncia à subalternidade desses infantes, por trazer à tona as dificuldades enfrentadas pelos pequenos descendentes de escravos, desde a identidade renegada à impossibilidade de ser criança e as suas ausências da história oficial. 
Órfã de pai e mãe e com avó analfabeta a menina Daiane era desprovida de quase tudo. Porém, disfarça suas dificuldades, não quer se curvar a elas, dissimula o choro na sala de aula ao se ver chacoteada e exposta pelo outro: "Daiane não tem pai nem mãe, e sua avó é analfabeta, por isso não sabe fazer nada" (PRADO, 2009, p. 41). Nesse sentido, a narrativa, mais uma vez, aproxima-se dos romances de Conceição Evaristo, pois cria crianças fortes em um contexto de privações e humilhações.

A partir de vários pontos os infantes são apresentados. A narrativa de Prado, por exemplo, não apenas representa uma criança com dificuldades, mas em meio ao pranto, logo, quando o leitor talvez imagine uma tragédia para Daiane, a narradora é generosa, manifesta outra faceta. A garota também ria. Os motivos do contentamento são análogos aos das personagens de Conceição Evaristo, Maria-Nova e Ponciá, eram os dias em que ouviam histórias dos negros e dessa maneira as culturas afro-brasileiras são apresentadas nas narrativas:

\footnotetext{
Vó, hoje tem histórias?

- Claro minha Pretinha. O povo negro tem muitas histórias importantes e bonitas que as pessoas têm que saber. Na escola você não aprendeu sobre as rainhas e as princesas negras? (PRADO, 2009, p. 43).
}

Esse era o tempo do autoconhecimento. Tempo em que Daiane não seria apontada pelo outro com negatividade, era o momento do esclarecimento das identidades negras, fortes e resistentes. Esse é o tempo e espaço da infância, o momento da dignidade e da positividade das identidades infantis negras.

O surgimento desses textos sinaliza que esse também é o tempo e espaço das produções de escritores negros e escritoras negras. É o tempo e espaço da literatura afro-brasileira mostrar sua singularidade e autonomia.

Em vias de análise, as personagens infantis aqui estudadas vivenciam "a força bem como a vulnerabilidade do conhecimento não socializado, mal-interpretado ou depreciado" (KOHAN e KENNEDY, 2000, p. 11). Nesse sentido as narradoras lhes dão vozes e propõem-se a ouvi-las, bem como recusam a oferecer uma infância idealizada e romantizada. Desse modo, elas lançam a possibilidade de pensar os fundamentos que naturalizam a exclusão da infância dessas personagens, a quebra das obviedades em torno da infância e a problematização dos seus espaços sociais.

Conceição Evaristo tem algo a nos dizer para nos relacionarmos de outra forma com esse outro, que é a infância das crianças negras. Para tanto, cabe conhecermos os becos cruzados por essa escritora polígrafa - poetisa, contista e romancista. 
Esse itinerário inicia-se em 1990 com a publicação de seis poemas no volume 13 dos Cadernos Negros. Mas destacou-se com as publicações individuais dos romances Ponciá Vicêncio (2003) e Becos da memória (2006), e, mais adiante, com o livro de poesia Poemas da recordação e outros movimentos (2008); e de contos Insubmissas lágrimas de mulheres (2011). Algumas das várias publicações coletivas nos Cadernos Negros de poesia e contos merecem ser destacadas:

Nos números de poesia publicou: Mineiridade; Eu-mulher; Os sonhos; Vozesmulheres; Fluida lembrança; Negro-estrela no volume 13 de 1990. Recordar é preciso; Menina; Brincadeiras; Pão; Meu corpo igual; Favela; Filhos na rua; Pedra, pau, espinho e grade; Bus; Meu rosário e Stop do volume 15 de 1992. Malungo, brother, irmão; A noite não adormece nos olhos das mulheres e $O$ escrever... do volume 19 de 1996. Todas as manhãs; Os bravos e serenos herdarão a terra; Para a menina; Se à noite fizer sol; M e M; Tantas são as estrelas... do volume 21 de 1998. De mãe; Da velha à menina; Da menina, a pipa; Do menino, a bola e Da esperança, o homem do volume 25 de 2002.

Já nos volumes de contos foram: Di Lixão e Maria do volume 14 de 1991. DuzuQuerença do volume 16 de 1993. Ana Davenga do volume 18 de 1995. Quantos filhos Natalina teve? Volume 22 de 1999. Beijo na face volume 26 de 2003. Olhos d'água e Ayoluwa, a alegria do nosso povo do volume 28 de 2005. Zaita esqueceu de guardar os brinquedos do volume 30 de 2007.

Mesmo em plena produção literária, acabou de publicar o livro de contos Olhos d'água, a fortuna crítica de Conceição Evaristo ainda está sendo formada. O que temos são poucas dissertações de mestrado, teses de doutorado, prefácios e as raras críticas em livros de antologia crítica como a de Eduardo de Assis Duarte e Maria Consuelo Cunha, Literatura e afrodescendência no Brasil: antologia crítica (2011). Os quais dizem que toda a criação literária de Conceição Evaristo está "profundamente marcada por sua condição de mulher negra na sociedade brasileira” (DUARTE e CUNHA, 2011, p. 208).

Duarte e Cunha sinalizam que as chaves do projeto literário de Evaristo estão conectadas à representação, em tom poético, da "crueldade do cotidiano dos excluídos. A mescla de violência e sentimento, de realismo cru e ternura, revelam o compromisso e a identificação da intelectual afrodescendente com os irmãos colocados à margem do desenvolvimento" (DUARTE e CUNHA, 2011, p. 208). Todavia as incursões de violência em Evaristo distinguem-se dos "procedimentos de um Rubem Fonseca" devido à adoção de um "ponto de vista interno" (DUARTE e CUNHA, 2011, p. 208). 
Do cruzamento desses becos surgem personagens infantis que são meninos de rua, pedinte, trabalhadores, artistas, crianças violentadas etc. Na tentativa de contribuir, também, para o acréscimo da fortuna crítica de Conceição Evaristo, estabelecerei um diálogo entre o conceito de representação em uma conjuntura discursiva teórica atual, no Capítulo I desta dissertação; junto com a problematização do conceito de literatura afro-brasileira, no Capítulo II; e da apresentação do ideal de infância bem como os modos de negociação nos romances Ponciá Vicêncio e Becos da Memória, no Capítulo III. 
I

Representação-efeito na literatura afro-brasileira 


\begin{abstract}
"Entre o acontecimento e a narração dos fatos, alguma coisa se perde e por isso se acrescenta. O real vivido fica comprometido. E quando se escreve o comprometimento (ou não comprometimento) entre o vivido e o escrito aprofunda mais o fosso. Entretanto, afirmo que, ao registrar estas histórias, continuo no premeditado ato de traçar uma escrevivência”.
\end{abstract}

Conceição Evaristo. In Insubmissas lágrimas de mulheres.

\title{
1. 1 Representação: a prosa em fratura
}

Este capítulo propõe uma reflexão sobre o conceito de representação em uma conjuntura discursiva teórica atual com referência aos romances Ponciá Vicêncio (2003) e Becos da Memória (2006). Pretende-se esclarecer como algumas concepções de representação são elucidativas para compreendermos de que ponto de vista partem os processos de construção desses romances e mais especificamente suas personagens infantis negras ${ }^{1}$. A abordagem também se estenderá a explicar em que medida a escolha do modo de representação, produzida nessas narrativas afro-brasileiras, rompe com o discurso hegemônico, e de que maneira ocorre esse descentramento da perspectiva de representação eurocêntrica.

A discussão parte de Luiz Costa Lima em Mímesis: Desafio ao pensamento (2000), texto em que o autor discute e nega a tradição que associa a mímesis à imitação. Costa Lima faz uma retificação a respeito do conceito de representação ao afirmar que o termo possui duas definições. A primeira se refere à imitatio, cópia exata da realidade, externa ao discurso literário, e a segunda possui uma relação com a mímesis:

\begin{abstract}
Em sua forma classicamente secundária, representação significa a equivalência entre uma cena primeira e a resposta subjetiva que provoca. $\mathrm{Na}$ primeira acepção, a representação tem caráter de aspecto (objetivo). $\mathrm{Na}$ segunda, o do efeito (Wirkung)- a identificação do efeito com a resposta subjetiva é provisória. A primeira satisfaz e é requerida pelas ciências duras. A segunda se espraia entre as ciências históricas (mais comumente chamadas humanas), alcança as situações cotidianas e inclui a resposta à obra de arte. (COSTA LIMA, 2000, p. 98-99).
\end{abstract}

Detalhadamente, Luiz Costa Lima apresenta essas duas acepções para o termo representação. Com base na dessacralização da natureza referenciada por Descartes, Costa Lima conclui que a primeira ideia de representação está vinculada a uma equivalência estabelecida idealmente de modo geométrico, entre uma cena empírica primeira e uma cena produzida e projetiva. Essa definição não estaria relacionada com a

\footnotetext{
${ }^{1}$ A discussão sobre a construção e representação das personagens infantis será apresentada no terceiro capítulo. Por ora, pretende-se apenas explorar o conceito de representação que norteia a perspectiva de análise.
} 
mímesis, mas com a imitatio ou com a semelhança imitada. A relação entre mímesis e representação só é possível quando se considera a segunda concepção, a "representaçãoefeito". Costa Lima problematiza que a não distinção dessas duas acepções só é interessante e confortável para quem pretende associar arte a realidade ou a quem busca um distanciamento completo da representação e realidade da obra de arte.

É na dissociação entre mímesis e imitação, que Luiz Costa Lima propõe uma releitura do conceito de mímesis. E esse trabalho de repensar a mímesis, rediscutindo a intuição Aristotélica é, logo, tratar da condição moderna do sujeito. "Só à medida que mostrássemos plausível conceber nos modernos outra concepção de sujeito, seria possível reestabelecer a ligação procurada com a mímesis" (COSTA LIMA, 2000, p. $74)$.

Então, a partir dessa reconsideração, estabelece-se a ideia do sujeito fraturado. "Nossa meta é apenas assinalar como é possível descobrir-se sob o cogito solar de um sujeito fraturado" (COSTA LIMA, 2000, p. 93). "A unidade do sujeito Kantiano implica alternativas antagônicas. Ou seja, fraturas”. (COSTA LIMA, 2000, p. 105). De alguma forma há um sujeito em unidade, mas no modo fraturado.

Desse modo, Costa Lima sugere a falência do sujeito cartesiano (solar) em contraponto ao fraturado, que não possui posição definida ou estável, se apresenta sempre variável, e quase nunca afinado com suas outras posições, mas assume circunstancialmente uma delas, a partir do meio em que esse sujeito se encontra: "Exatamente porque o sujeito é fraturado, ele não tem uma posição a priori definida, senão que assume, assim se identificando, no interior dos conflitos de interesse e na assimetria dos grupos sociais" (COSTA LIMA, 2000, p. 23). A definição do sujeito fraturado não se dá apenas pela simplificação do ato de não ser único e do não comando de suas representações, mas abrange a ideia de uma dupla função, a de "apresentar e receber; produzir e suplementar".

A ideia da falência do sujeito solar também é perceptível nas abordagens de Stuart Hall em A identidade cultural na pós-modernidade (2006). Sob uma perspectiva epistemológica que pode ser aproximada à de Costa Lima (2000), Hall (2006) fala em "crise das identidades" / "sujeito fragmentado", supõe que as identidades que por muito tempo estabilizaram o mundo social estão em declínio, o que garante o surgimento de novas identidades e ocasionando o fragmento do indivíduo moderno. De modo que a “"crise de identidade' é vista como parte de um processo mais amplo de mudanças, que está deslocando as estruturas e processos centrais das sociedades e abalando os quadros 
de referências que davam aos indivíduos uma ancoragem estável no mundo social" (HALL, 2006, p. 7).

A justificativa para pontuar o declínio do sujeito solar, uno, imperial e originário reside na ideia de que essa concepção que dominou o pensamento moderno possui implicações danosas para a compreensão da arte, além de limitar a definição de representação-efeito:

\begin{abstract}
As implicações da concepção dominante não podiam ser mais diretas: se o sujeito comanda as representações e, sendo a mímesis um modo de representação, ela não passaria de uma das emanações do sujeito. Mais precisamente, uma das tantas ilusões que o homem se criara, com resultado danoso para a compreensão da arte. Além do mais, para que o sujeito fosse tomado como a fonte originária das representações e, em especial, dessa representação específica, a mímesis, era preciso que a representação fosse entendida como uma construção equivalente a algo prévio a ela, constituindo uma espécie de maquete do mundo externo, cuja reprodução com a pretensão explícita ou tácita de seu domínio, era assim assegurada. A essa caracterização viemos a chamar de representação 1. Desta maneira era deixada como irrelevante a representação 2 , i.e., a representação-efeito, que, a princípio, antes de considerarmos seu trato específico no horizonte da arte, nos contentávamos em definir como aquela que se engendra no sujeito, à maneira de resposta afetiva ante fenômenos ou acontecimentos ( COSTA LIMA, 2000, p. 230)
\end{abstract}

Esses conceitos sujeito fraturado/sujeito fragmentado e representação-efeito convergem em questões relativas à posição autoral e de recepção. A respeito da autoria dos romances em análise podemos perguntar: em que posição Conceição Evaristo se encontra, enquanto produtora dessas obras? Qual o seu local de voz? Quais os limites de representação das identidades negras? O que isso implica na arquitetura das narrativas? Ou que implicações esse local de voz sugerem para a representação de crianças negras? Como essas representações são percebidas pelo leitor da literatura afro-brasileira?

Ao considerar a existência de um sujeito fraturado, aquele que não é capaz de modelar e manter o comando de sua representação, é possível afirmar a existência de um caráter fragmentário da percepção autoral em Ponciá Vicêncio e Becos da Memória. Podemos também dizer que a perspectiva de representação de Conceição Evaristo é baseada nas ideias de representação-efeito, aquela alicerçada nos afetos provocados no sujeito, a "representação atualizada por imagens afetivas" (COSTA LIMA, 2000, p. 114). O "efeito é a precipitação (atualização) em um receptor de uma organização representativa. Pode-se acrescentar que essa organização, sendo de ordem sociocultural, é relativamente independente do objeto que se apresenta" (COSTA LIMA, 2000, p. $115)$.

Assim, a mímesis é um fenômeno recepcional, ela será sempre uma experiência nova, pois é provocada não por uma cena referencial, mas pela atualização/expressão da 
cena no sujeito, o que impede a confusão entre mímesis e imitatio (COSTA LIMA, 2000, p. 98).

Vale lembrar que, ao definir o conceito de literatura afro-brasileira, que será tratado mais adiante, Eduardo de Assis Duarte (2011, p. 397) considera como uma das variáveis centrais na construção dessa literatura o leitor afro-brasileiro, entendido como aquele a quem os textos desse corpus se dirigem, sem que isso exclua, evidentemente, outros grupos etnicorraciais como leitores potenciais desses textos.

Luiz Costa Lima ratifica essa concepção de representação em Frestas: $a$ teorização em um país periférico (2013), no qual diz que o realce da posição do observador requer uma reformulação do princípio de representação. Dentre destes parâmetros, o pesquisador entende a representação como dependente do sujeito, por não ser possível a neutralidade do sujeito representante:

O efeito suscitado em um sujeito por um fenômeno seja objetal - uma coisa com que nos defrontamos -, seja subjetivo - a ocupação da mente por algo presente, pela recordação ou antecipação de algo ou alguém, prazenteiro ou pavoroso. Considero, por conseguinte, que a representação - salvo nas situações-limites das condutas absolutamente robotizadas ou, se isso for possível, nas formulas cuja matematização não seja afetada pela posição do observador - está sempre acompanhada de um efeito. O que significa que a representação não se dá independentemente de quem a tenha ou que o sujeito, durante o processo de representação, a tal ponto neutralize sua singularidade, composta de razão e paixões, que venha a dispor do objeto tal qual (COSTA LIMA, 2013, p. 132).

A própria ficcionista faz referência à representação atualizada por imagens afetivas, ou esse fenômeno recepcional ao falar em "escrevivência" ${ }^{2}$ - a consideração das marcas autobiográficas e o testemunho ou precisamente a interação escritura e experiência (EVARISTO, 2007). Evaristo declara que a origem da sua escrita está associada ao acúmulo de tudo que ouviu desde a infância. "O acúmulo das palavras, das histórias que habitavam em nossa casa e adjacências" (EVARISTO, 2007, p. 19). Essa declaração também confirma a ideia de Costa Lima de que a "representação-efeito não significa algo privado, mas sim que é um fenômeno que liga, não deterministicamente, o sujeito receptor com a coletividade a que se integra, por seu horizonte de expectativas" (COSTA LIMA, 2000, p. 115 e 116). Assim, há uma percepção de uma experiência individual, mas que está ligada a uma coletividade.

O privado, o coletivo e o fragmentário ficam bem evidentes na estética narrativa de Becos da Memória. A trama é colocada na perspectiva da criança Maria-Nova, mas a(s) narradora(s) também apresenta(m) a visão de outras personagens. O enredo é

\footnotetext{
${ }^{2} \mathrm{O}$ conceito de escrevivência será detalhado no próximo capítulo, quando será explicada a ideia de autoria na literatura afro-brasileira.
} 
organizado ao modo de um mosaico, em trechos e não em capítulos o que sugere o limite da visão da própria Maria-Nova sobre a história dos negros favelados. Os fatos não são ditos de forma completa. Algumas personagens são construídas de forma precária e fragmentada. De modo Imprevisível, especialmente no caso das crianças $^{3}$, as personagens aparecem chocando o leitor e logo somem da ficção, ao mesmo tempo, permanecem simbolicamente em outras personagens, pois os destinos das mesmas não parecem se diferenciar tanto. Nessa tessitura fraturada, embora Maria-Nova tenha destaque, Evaristo compõe o protagonismo coletivo.

Uma vez que o sujeito é fraturado, a representação produzida por este é alicerçada nas inclinações/ afetos/ local de voz, logo, sua produção artística também será fraturada. Essa tendência é manifesta nas referências ao real exibidas nos romances em análise. A visão das narradoras em relação à revisão da história da escravidão, a vida na roça pós-escravidão e a situação dos afro-brasileiros na favela são trazidas em uma perspectiva de dor e sofrimento, e isso não é a equação de toda uma história, apenas parte ou uma versão dela, pois nessa mesma história poderiam caber muitas outras versões. A variação estaria atrelada à representação que foi engendrada no sujeito produtor da arte literária. No trecho de Ponciá Vicêncio, a seguir, essa representação está caracterizada:

Os negros eram donos da miséria, da fome, do sofrimento, da revolta suicida. Alguns saíam da roça, fugindo para a cidade, com a vida a fartar de miséria, e com o coração a sobrar de esperança. Ela mesma havia chegado à cidade com o coração crente em sucessos e eis no que deu. Um barraco no morro. Um ir e vir para a casa das patroas. Uma sobra de roupas e de alimentos para compensar o salário que não bastava. Um homem sisudo, cansado, mas do que ela talvez, e desesperançado de outra forma de vida (EVARISTO, 2003, p. 82).

Esse modo de representação também pode ser percebido em Becos da Memória, como se vê a seguir:

\begin{abstract}
As pessoas estavam num desespero tal, que queriam de qualquer forma abreviar o sofrimento. Havia famílias que quando o caminhão de mudanças aparecia, elas mesmas se ofereciam para ir. Ficar ali se havia tornado um inferno. $\mathrm{O}$ bicho pesadão campeava durante todo o dia e nas noites de estrelas iluminando a terra, a fera campeava pelo tempo adentro e tudo era poeira e desespero. Havia ainda a escassez, a falta dágua. Em algumas construções do bairro vizinho, à noite, o rodante dava aos favelados algumas latas dágua. Era um exercício cansativo. Andávamos, muitas vezes, quase uma hora com uma lata na cabeça e outra pendurada nas mãos... os que resistiam não sabiam como e por quê (EVARISTO, 2006, p. 142 e 143).
\end{abstract}

\footnotetext{
${ }^{3}$ Inicialmente no último capítulo, na página 72 apresentamos uma lista das personagens infantis dos dois romances. A lista mostra personagens que pouco aparecem na trama, mas que deixam marcas no leitor pela modo contundente que são configurados.
} 
Além de tantas outras situações de fratura, nas tramas, cabe pontuar a fratura impressa por meio da protagonista de Ponciá Vicêncio, a qual se mostra um sujeito fraturado, por apresentar visão limitada de sua realidade e por não compreender todas as nuances do jugo e da escravidão a que foi submetida, que apesar da "Lei Áurea", se mostrava "eterna como Deus":

Depois de andar várias horas, Ponciá teve a impressão de que havia ali um pulso de ferro a segurar o tempo. Uma soberana mão que eternizava uma condição antiga. Várias vezes seus olhos bisaram também a cena de pequenos, crianças que, com a enxada na mão, ajudavam a lavrar a terra. (EVARISTO, 2003, p. 49).

Esse conjunto de referências é resultado de um discurso produzido em um local social específico. A escolha originou-se mediante uma percepção parcelada da realidade, ou seja, de acordo com a posição social de Conceição Evaristo. Sua condição de mulher e escritora negra, descendente de escravos, ex-moradora da favela da zona sul de Belo Horizonte, ex-doméstica, pobre, bem como sua entrada tardia no mercado formal de trabalho condicionaram suas produções literárias. Fica claro que as imagens de mundo pontuadas em Ponciá Vicêncio e em Becos da Memória são critérios de seleção da escritora, face aos contextos de referência que lhe foram dados pela sua trajetória cultural.

Reforço que se a autora produz a partir de um lugar de voz, socialmente demarcado, Ponciá Vicêncio e Becos da Memória apresentam diagnóstico da situação histórica dos afro-brasileiros, mas não é capaz de trazer uma ideia totalizante da grande complexidade pressuposta nesse fato histórico, pois em vez de refletir diretamente o real, ou mesmo refratar o real, o discurso artístico constitui a refração de uma refração, ou seja, uma versão mediada de um mundo sócio-ideológico que já é texto e discurso (SHOHAT e STAM, 2006, p. 264).

Ao postular a ideia do sujeito fraturado, Costa Lima (2000) evidencia o surgimento do fragmento na prosa. A perspectiva autoral de Ponciá Vicêncio e Becos da Memória, que mirou na representação social cotidiana da criança negra não se mostrou capaz de trazê-la à plenitude de seu sentido. Essa representou algumas das perspectivas e não a ideia totalizante das crianças negras brasileiras. A autora não alimenta um realismo "corretivo", descrito por Shohat e Stam como aquele que "parece se resumir a uma simples questão de identificar "erros" e "distorções", como se a "verdade" de uma comunidade fosse simples, transparente e facilmente acessível, e "mentiras" fossem facilmente desmascaradas" (SHOHAT e STAM, 2006, p.261). Essa mesma referência à 
ideia da impossibilidade de representar a totalidade do objeto é também marcada por Barthes (2013), pois na perspectiva do teórico:

É sem dúvida, na exata medida de nossa atual alienação, que não conseguimos ultrapassar uma apreensão estável do real; nós caminhamos incessantemente entre o objeto e a sua desmistificação, incapazes de lhes oferecer a totalidade: pois se penetrarmos no objeto, libertamo-lo, mas destruímo-lo; e, se lhe deixemos o peso, respeitamo-lo, mas devolvemo-lo ainda mistificado. Parece que estamos condenados, durante certo tempo, falar excessivamente do real. É que, por certo, a ideologia e o seu contrário são comportamentos ainda mágicos, aterrorizados, ofuscados e fascinados pela dilaceração do mundo social. E, no entanto, é isso que devemos procurar: uma reconciliação entre o real e os homens, a descrição e a explicação, o objeto e o saber (BARTHES, 2013 p. 251).

Para afunilar a questão relembro que Costa Lima expõe a relação do sujeito fraturado e da representação ao definir a mímesis: "De modo geral, podemos dizer que a mímesis supõe correspondência entre uma cena primeira, orientadora e geral, e uma cena segunda particularizada numa obra" (COSTA LIMA, 2000, p. 22). De tal modo, Ponciá Vicêncio e Becos da Memória não são a cópia de uma cópia, porque a "semelhança não é em si mesma suficiente" (TAUSSIG, apud COSTA LIMA, 2000, p. 22). Enfatizo que Evaristo representou uma das várias perspectivas possíveis para a história das crianças, filhos de escravos e seus descendentes. Em outras palavras, a utilização de referências ao real foi apenas uma orientação e não uma modelação. De acordo com Costa Lima (2000):

Em termos Kantianos, uma representação que viabilizasse a correspondência com uma cena natural e anterior teria por consequência provocar $o$ mecanismo próprio a um juízo determinante e terminar na regulação da lei. $\mathrm{Ou}$, quando nada, seria recebida como se do primeiro tipo, sendo própria de uma experiência inferior da beleza, a 'beleza aderente'. Portanto aquele que opta por um cenário realista é o que mais busca ou se arrisca a retirar seu receptor de uma experiência estética (COSTA LIMA, 200, p. 115).

Portanto, esses romances configuram uma perspectiva de realismo, que não é a representação do real, mas parte de uma perspectiva realista da autora: "porque se a obra corta todas as amarras com a verdade... continuará no melhor dos casos, num mundo paralelo que... não permitiria ao leitor nenhuma entrada" (COSTA LIMA, 2000, p. 61), ou quando o cenário é puramente realista, como dito anteriormente, arrisca retirar a possibilidade de uma experiência estética. É por meio desse vínculo com o mundo empírico que é possível fazer a leitura do mundo ficcional. A crítica do romance Ponciá Vicêncio marca essa tendência, de Conceição Evaristo, ao efeito realista:

Ponciá, na verdade, simboliza o espaço e o tempo de uma história contundida, de exclusão e subserviência que foi imposto ao povo afrodescendente brasileiro. Ficção e realidade se imbricam nas camadas 
narrativas, todavia o que vai aflorando é uma escrita tensa e densa de dizeres sofridos, numa lírica contundente. (SILVA, 2007, p. 73)

Embora o "mundo" apresentado no romance Ponciá Vicêncio, não seja decalque de um mundo preexistente, sua constituição se realiza em diálogos com esse, do qual retira os elementos que serão reformulados a partir de uma linguagem específica:

O mundo real participa na formação de mundos ficcionais fornecendo modelos de sua estrutura (inclusive a experiência do autor), ancorando a história ficcional em um acontecimento histórico [...] transmitindo "fatos brutos" ou "realemas" culturais. [...] O material que o mundo real fornece tem que sofrer uma transformação para ser admitido no mundo ficcional: ele deve ser convertido em possíveis não-reais, com todas as consequências lógicas, ontológicas e semânticas (JEHA, 1993, p. 85).

Shohat e Stam, em Crítica da imagem eurocêntrica, fundamentados nas reformulações do conceito de representação de Bakhtin, buscaram desviar-se dos termos "verdade" e "realidade", mas concordam que a arte possui um elo com o social, pois ela é "inegavelmente social, não porque representa o real, mas porque constitui uma "enunciação" situada historicamente - uma rede de signos endereçados por um sujeito ou sujeitos constituídos historicamente para outros sujeitos constituídos socialmente, todos imersos nas circunstâncias históricas" (SHOHAT e STAM, 2006, p.265). Por outro viés Costa Lima (2000) também apresenta sua ideia sobre o elo literatura e mundo, no sentido de aspectos sociais:

Como a qualquer texto literário é impossível desligar-se do antes ou do depois do texto. Se a literatura depender desse desligamento, do desligamento tanto se pode dizer que é impossível como que é desaconselhável. Em termos estritos, a literatura abstrata exigiria o cancelamento dos dicionários. Ou seja, de um povo que fala uma língua. Será exagero dizer que sua impossibilidade de abolir o resto do sujeito e mundo significa a impossibilidade de desligar-se da mímesis? Pois que é a mímesis senão uma oficina de correspondências? (COSTA LIMA, 2000, p. 289).

Desse modo, fica claro que a literatura é uma produção carregada de ideologias e discursos voltados a um sujeito, “é uma representação não tanto no sentido mimético, mas político, uma delegação de vozes" (SHOHAT e STAM, 2006, p. 265). Baseando-se nesse suporte teórico de Shohat e Stam e considerando as ideias de Pitkin $(1985)^{4}$ sobre a representação, é possível dizer que a representação literária também é política porque a posição adotada por um autor dependerá de sua concepção sobre a natureza humana e a vida política. A visão de representação não será arbitrária, mas estará atrelada a um pensamento político. Os romances de Conceição Evaristo transparecem essa visão, pois

\footnotetext{
${ }^{4}$ Em El concepto de representación, Pitkin discute o conceito de representação política, o qual é aproveitado nessa discussão para apontar que a representação literária também é uma representação política, no caso da literatura afro-brasileira observa-se um engajamento político especial graças a algumas constantes discursivas e critérios de configuração dessa literatura.
} 
se trata de uma literatura negra engajada a um movimento para reconstruir a imagem do afrodescendente, o qual toma para si a missão de fazer sua própria literatura.

Hanna Pitkin, ao examinar o conceito de representação sob a perspectiva da ciência política, rejeita as concepções ortodoxas e propõe uma mudança radical na concepção de representação centrada nas intenções e atos dos indivíduos. Nesse sentido

o termo é visto não como um atributo pessoal, mas uma atividade social, portanto coletiva, como também defende, no campo da teoria literária, Costa Lima (2000) e, no ponto de vista da criação, Evaristo (2007). A teórica também define representação como responsabilidade do representante às prioridades dos representados:

\begin{abstract}
A representação política é, de fato, representação, particularmente no sentido de "agir em nome de" e de que isso precisa ser entendido no nível público. O sistema representativo precisa cuidar do interesse público e ser responsável perante a opinião pública, exceto quando, e na medida em que, sua não _ responsabilidade possa ser justificada em termos de interesse público (PITKIN, 1985, p. 124).
\end{abstract}

Pitkin aponta para uma crise da representação política, uma vez que as eleições são instrumentos insuficientes de expressão da soberania popular. Os partidos então são cada vez menos capazes de representar opiniões, interesses, valores, principalmente em referência às novas identidades que surgem nas sociedades atuais. Essa crise na representação política parece ter elo com as representações do negro na literatura brasileira, uma vez que ela é pouco evidente e legítima, no ponto de vista de representação de identidade, valores e cultura afro-brasileira.

A autora constrói seu conceito de representação como uma atividade de agir por outros; e enfatiza neste conceito a equivalência entre representante e representado e a exigência paradoxal de que o sujeito substituído pelo representante esteja de alguma forma presente. Pitkin aponta uma perspectiva importante ao diferenciar a representação política da representação privada e relevando que há um conflito irredutível entre representação política e representado, distintamente do que ocorre na relação privada.

Esses pressupostos, juntamente com as propostas de Costa Lima (2013, p. 133) de que "entre os efeitos e a declaração de sua validade se interpõe o quadro teórico, de acordo com o qual os efeitos serão examinados e então legitimados ou recusados", nos direcionam a voltarmos à questão autoral, mas agora com o foco na autorização e legitimação. Surge então a interrogação de quem está autorizado/legitimado para representar os afro-brasileiros? A percepção ou o efeito do real em Conceição Evaristo tem "plausibilidade"? Os pressupostos relacionados à história e culturas dos negros levantados pela autora são aceitos? 
Diante de uma literatura dominante, a literatura afro-brasileira recusa a ideia de fragilidade intelectual do negro, que supostamente necessita do outro (branco) para falar por ele. Essa literatura surge com a exigência do direito de uma representação justa, uma literatura do negro, sobre o negro e para o negro.

Ao falar sobre a especificidade da literatura afro-brasileira, Duarte (2008) assinala que um dos elementos que permitem que ela seja "distinta das letras nacionais" é a exigência de uma autoria negra ${ }^{5}$, ou seja, "uma escrita proveniente de autor afrobrasileiro, e, neste caso, há que se atentar para a abertura implícita ao sentido da expressão, a fim de abarcar as individualidades muitas vezes fraturadas oriundas do processo miscigenador" (DUARTE, 2008, p. 12).

Desse modo Conceição Evaristo, na condição de mulher negra, que assume um ponto de vista de uma identidade negra, possui, sim, legitimidade para representar o negro, o lugar de onde ela fala é dos oprimidos e este é um dos fatores decisivos para incluir a sua obra no âmbito da afro-brasilidade.

\subsection{Representação: Uma questão de percepção}

As questões discutidas na sessão anterior já permitem a compreensão de que a representação não está atrelada somente à busca pelo olhar do outro ou ao respeito por suas peculiaridades. Mas, sobretudo, na diversidade de percepção, ou seja, "a questão, portanto, não é a fidelidade a uma realidade preexistente, mas a orquestração de discursos ideológicos e perspectivas coletivas". (SHOHAT e STAM, 2006. p. 265). O ponto não é ser fiel, mas sim que tipo de discurso essa representação produz.

A construção das personagens dos romances em estudo deixa clara a opção por essa diversidade. Primeiro pela escolha de representar mulheres e homens negros em diferentes faixas etárias (crianças, jovens, adultos e velhos); a encenação de personagens com identidades fragmentadas; apresentação de ambientes urbanos e rurais. E por suas temáticas não estarem restritas à denúncia ou lamento da senzala, mas ampliarem-se para também apresentar o negro que ama, sofre, ri e reage. Desse modo, Evaristo pautou-se na circunscrição das margens para compor as personagens:

\footnotetext{
${ }^{5}$ Vale adiantar que as questões mais pontuais acerca da autoria da literatura afro-brasileira serão discutidas no próximo capítulo.
} 
Assim, uma descrição consequente de "um outro pensamento" é a seguinte: uma maneira de pensar que não é inspirada em suas próprias limitações e não pretende dominar e humilhar; uma maneira de pensar que é universalmente marginal, fragmentária e aberta; e, como tal uma maneira de pensar que, por ser universalmente marginal e fragmentária, não é etnocida (MIGNOLO, 2003, p.104).

As narrativas de Conceição Evaristo fazem o caminho contrário da maioria dos romances, que não representam as classes populares, ou que, quando o fizeram, foi de maneira exótica: "Quase sempre expropriados na vida econômica e social, aos integrantes dos grupos marginalizados lhes é roubada, ainda, a possibilidade de falar de si e do mundo ao seu redor" (DALCASTAGNÈ, 2012, p. 20 e 21). De modo que as narradoras de Evaristo tomaram para si a função de mediar e representar uma classe social subalterna. Fizeram isso por meio de um discurso baseado em personagens marginalizadas e oprimidas. Trata-se de narradoras que têm o exercício de dar voz ao outro. E essas vozes são mais marcantes em personagens socialmente desimportantes, a criança, por exemplo.

A ficcionista posiciona os subalternos no centro da narrativa, as personagens coadjuvantes também ganham destaque de herói/protagonista. Isso se aproxima do que Walter Mignolo (2003) defende sobre a razão do outro e o "pluricentrismo".

Mignolo (2003) discute a superficialidade da História ao contar apenas a versão do colonizador das histórias dos povos colonizados e a capacidade da literatura de refletir de maneira mais ampla as memórias dos povos: “... Só o saber poético, ficcional, o saber literário; em resumo o saber artístico pode descobrir-nos, compreender-nos e trazer-nos evanescentes, de volta à ressurreição da consciência" (MIGNOLO, 2003, p. 99). Desse modo, os romances de Evaristo são importantes por relerem criticamente a história da escravidão, pelo apontamento da exclusão que esgarçou a identidade cultural dos povos negros pelos ideais colonialistas.

Ainda em Histórias locais/ projetos globais - colonialidade, saberes subalternos e pensamento liminar, Mignolo (2003), ao se referir à colonialidade do poder, elucida que a formação latina está enraizada em um imaginário marcado por uma colonização eurocêntrica, apontando como a ideia que determinados teóricos produzem em locais geoistóricos é vista como superiores e universais:

A colonialidade do poder e a dependência histórico-estrutural implicam ambas a hegemonia do eurocentrismo como perspectiva epistemológica... No contexto da colonialidade do poder, a população dominada, nas novas identidades que lhes haviam sido atribuídas, foram também submetidas à hegemonia eurocêntrica como maneira de conhecer (Quijano explica como "índio e "negro" foram identidades homogeinizantes estabelecidas pela colonialidade de poder, apagando a diversidade das identidades " índia" e negra). ( QUIJANO, 1997, p. 117 apud MIGNOLO, 2003, p. 85). 
Dentro dessa perspectiva, Mignolo busca desconstruir a tradicional visão hegemônica eurocêntrica acerca da ciência e do conhecimento, questionado se tais teorias possuem o mesmo papel e relevância no seu local de origem e no lugar migratório. Ele aponta para a emergência do "pensamento liminar" a partir da diferença colonial, ressaltando que:

\begin{abstract}
Nesse ponto, a dupla crítica é uma estratégia crucial para a construção de macronarrativas na perspectiva da colonialidade. Como tais, essas macronarrativas não estão predestinadas a enunciar a verdade que os discursos coloniais não contaram. Esse passo já está implicado na dupla crítica. Na perspectiva da colonialidade, as macronarrativas são precisamente os lugares nos quais "um outro pensamento" poderia ser implementado, não para dizer a verdade em opção às mentiras, mas para pensar de outra maneira, caminhar para "uma outra lógica"- em suma para mudar os termos, e não apenas o contexto da conversação. Essas narrativas propiciam pensar a colonialidade, e não apenas a modernidade, de forma livre (MIGNOLO, 2003, p. 106).
\end{abstract}

A colonialidade do poder configura historicamente uma geopolítica do conhecimento em que pensar é privilégio dos "iluminados" que estão localizados em determinados lugares geoistóricos do globo. De igual modo, ao pensar sobre a produção literária, não surpreende que "na narrativa brasileira contemporânea é marcada a ausência, quase que absoluta de representantes de classes populares... é possível descrever nossa literatura como sendo a classe média olhando para a classe média" (DALCASTAGNÈ, 2012, p. 18). Ou seja, a literatura é privilégio das classes dominantes, não cabendo aos grupos subalternos a autorrepresentação, pois nessa visão eles não teriam domínio das técnicas da "alta literatura".

Conceição Evaristo então propõe nessas tramas "um outro pensamento", um outro fazer literário, que não quer se ver único, aos moldes dominantes. Imprime um deslocamento do discurso literário, que há muito esteve centrado nos discursos coloniais em que; "não só a universalidade da literatura branca é imposta, mas o é através de sua dominação pela força", assim, os negros "se deparam com um dilema fundamental; as técnicas e a linguagem que usam são técnicas e linguagem branca" (BARBOSA, 1995, apud LOBO, 2007, p. 265). Portanto, sai da hegemonia, dos centros para manifestar as margens. Assume a voz intelectual da camada marginal que representa um grupo marginalizado.

Ponciá Vicêncio e Becos da memória são obras que não se rendem ao olhar etnocêntrico e nem repetem o discurso do cânone hegemônico, pois não se apropriam de forma mecânica do discurso do outro. Fazem isso quando sinalizam o etnocentrismo que exclui o negro do letramento e da sociedade e ao desviar-se do fazer literário canônico. 
Essa ruptura do centro como referência é um modo estratégico de não reforçar a tradição de que algumas obras sejam canonizadas e outras relegadas a critérios hegemônicos: "A postura estratégica mais rentável para descentrar o centro e reconfigurar as margens reside no processo de disjunção e deslocamento desse referencial, pois somente dessa forma poderemos assumir a nossa cultura como registro dos imaginários múltiplos que nos constituem" (SCHMIDT, 1996, p. 21). É isso que Conceição Evaristo faz. Suas narrativas são constituídas a partir das lentes das culturas africanas, como será apresentado no Capítulo III.

Em Mignolo fica claro que o pensar a partir de experiência subalterna contribui tanto para a autocompreensão quanto para as políticas públicas, que criam condições para transformar as relações de subalternidade. Para ele a literatura não pode ser concebida como objeto de estudo, mas como produção do conhecimento teórico, não como representação de algo, sociedades ou ideias, mas reflexão, à sua própria moda, dos problemas de interesse humano e histórico.

Em Ponciá Vicêncio e em Becos da Memória o negro deixa de ser objeto e passa a ser representado como sujeito - fraturado - da literatura, deixa de ser apenas tema estereotipado para ser autor/agente, com uma visão de mundo particular e ao mesmo tempo, coletiva. "Foi o branco que criou o negro" e que os negros ao se autoproclamarem como tal, querem conscientemente "criar a si mesmos" (LOBO, 2007, p. 326), querem se autorrepresentar, falar por si mesmo.

Os romances figuram uma literatura Marginal, por além de ser literatura de produção de uma escritora negra que fala de uma história invisibilizada, ser também marginal por encontrar-se longe da rota comercial dominante de produção e divulgação, circula apenas em sistema editorial alternativo, a Mazza edições e, recentemente, em 2013 a $2^{\text {a }}$ edição de Becos da memória pela Editora Mulheres. As edições estão esgotadas, portanto, quase sempre, só estão disponíveis em sebos, raramente em livrarias, ou nunca em livrarias.

Pierre Bourdieu, em As regras da arte (1996), ao analisar as dinâmicas de visibilidade, legitimação e consagração de escritores dentro do campo literário, argumenta que a prática do escritor pode ser explicada com referência ao "campo de poder", esclarecendo que no interior desse campo encontra-se o campo literário ocupando uma posição dominada:

Em razão da hierarquia que se estabelece nas relações entre as diferentes espécies de capital e entre seus detentores, os campos de produção cultural ocupam uma posição dominada, temporalmente, no seio do campo do poder. Por mais livres que possam estar das sujeições e das solicitações externas, 
são atravessados pela necessidade dos campos englobantes, a do lucro, econômico ou político (BOURDIEU, 1996, p. 245-246).

"Embora o romance contemporâneo venha perseguindo reiteradamente, em seu interior, a multiplicidade de pontos de vista; do lado de fora da obra, não há o contraponto; quer dizer, não há, no campo literário, uma pluralidade de perspectivas sociais" (DALCASTAGNÈ, 2012). De modo que o campo literário tornou-se o das disputas de poder e o caminho para compreender os motivos da eleição de algumas estéticas literárias como sendo mais prestigiadas, o que leva à consagração de algumas obras, ao passo que, de outras, não. Consagração que ocorre em meio a essa relação de poder, quando uma elite detentora de capital, determinará as regras do que tem ou não valor, isso de acordo aos seus interesses capitais:

O campo do poder é o espaço das relações de força entre agentes ou instituições que têm em comum possuir o capital necessário para ocupar posições dominantes nos diferentes campos (econômico, cultural especialmente). É o lugar de lutas entre detentores de poderes (ou de espécies de capital) diferentes que, como as lutas simbólicas entre os artistas e os 'burgueses' do século XIX, têm por aposta a transformação ou a conservação do valor relativo das diferentes espécies de capital que determina, ele próprio, a cada momento, as forças suscetíveis de ser lançadas nessas lutas. (BOURDIEU, 1996, p. 224)

Escritores como Conceição Evaristo buscam uma autonomia diante dessa solicitação externa, ao rejeitar a busca pelo lucro e não ligar sua obra aos investimentos e aos rendimentos monetários nem tampouco buscar honras e grandezas temporais e supérfluas. Nesse sentido, de acordo com o que propõe Bourdieu:

\footnotetext{
Os autores que chegam a conseguir os sucessos mundanos e a consagração burguesa (a Academia especialmente) distinguem-se tanto por sua origem social e sua trajetória quanto por seu estilo de vida e suas afinidades literárias daqueles que estão condenados aos sucessos ditos populares (BOURDIEU, 1996, p. 249).
}

Quando se trata da produção da mulher, o campo literário mostra-se mais excludente, Spivak reflete sobre essa situação de subalternidade feminina: "Pode o subalterno falar? O que a elite deve fazer para estar atenta à construção contínua do subalterno? A questão da "mulher" parece ser mais problemática nesse contexto. Evidentemente, se você é pobre, negra e mulher, está envolvida de três maneiras" (SPIVAK, 2010, p.85). Portanto, o silenciamento e a invisibilidade de escritoras negras, como Conceição Evaristo, são maiores do que os das escritoras brancas. O combate a essa subalternidade não é resolvido falando por elas, mas através da criação de estratégias para que essas escritoras subalternas sejam ouvidas. 
Vírginia Woolf em "Um teto todo seu" (2004) sinaliza a dificuldade da escritora já no ato da produção artística, ao declarar que "a mulher precisa ter dinheiro e um teto todo dela se pretende mesmo escrever ficção" (WOOLF, 2004, p. 08). Para a autora a problemática instaurada na criação feminina está relacionada à ideia de que a feminilidade é uma “ocupação protegida”. A mulher nessa visão é protegida, no sentido de ser oprimida, resguardada e possuir limites sociais à semelhança de uma criança.

A autora solicita que "retirem-lhes essa proteção, exponham-nas ao mesmo esforço e atividades, forçam-nas soldados e marinheiros e maquinistas, e estivadores, e as mulheres não morrerão mais jovens - e mais depressa" (WOOLF, 2004, p. 51). Trazendo a discussão para a área do campo literário, há aí uma reinvindicação para as escritoras de um local de visibilidade. Não é isso que as escritoras negras querem? Serem expostas para que possam mostrar suas forças enquanto criadoras de arte? Uma vez expostas, suas obras "não morrerão mais jovens - e mais depressa" como costuma ocorrer com muitas escritoras da literatura afro-brasileira, as quais estão fora do mercado editorial brasileiro.

As reflexões sobre questões de gênero de Spivak (2010) parecem ser mais amplas que as contribuições de Woolf (2004), porque sinalizam também para as questões de raça, enquanto que Woolf restringe ao hipotetizar que a razão da omissão da mulher na literatura está atrelada à classe.

É possível entender que, nas narrativas em estudo, Conceição Evaristo rompe a ideia de proteção/ inferioridade dada à escrita feminina e negra. Fica evidente o empenho da ficcionista para combater a subalternidade das escritoras negras num ponto de vista legítimo que parte da perspectiva de "escrevivência". Ela sinaliza o potencial da mulher enquanto escritora negra e pobre, especialmente, por meio da personagem Maria-Nova, a qual a narradora atribui a missão de ser a futura registradora da memória dos povos negros.

\subsection{Representação: Ponciá Vicêncio e Becos da Memória}

Numa perspectiva descentrada, é possível vislumbrar estratégias de deslocamento do discurso eurocêntrico em Ponciá Vicêncio e Becos da Memória, graças à superioridade numérica de personagens negras em relação a brancos, o tratamento estético dado a essas personagens negras e o ponto de vista negro e feminino na obra. 
A construção da protagonista do romance de Ponciá Vicêncio, por exemplo, é uma interessante expressão do rompimento de Evaristo com a representação hegemônica da mulher negra. Pois, ao compor a personagem Ponciá Vicêncio, a escritora conclama a emergência de um novo protagonismo.

A romancista rejeita a representação do choro e lamento da senzala, recusandose a representar uma mulher conformada com sua condição de vida. Ao contrário, apresenta uma protagonista negra que não se convence da existência de uma ordem social justa, imposta pela elite; uma protagonista que não se mostra submissa, mas a questiona como atitude de resistência às relações de opressão, autoritarismo e dominação em busca de espaços de autonomia:

\begin{abstract}
Quando Ponciá resolveu sair do povoado onde nascera, a decisão chegou forte e repentina. Estava cansada de tudo ali. De trabalhar o barro com a mãe, de ir e vir às terras dos brancos e voltar de mãos vazias. De ver a terra dos negros coberta de plantações, cuidadas pelas mulheres e crianças, pois os homens gastavam a vida trabalhando nas terras dos senhores, e depois a maior parte das colheitas ser entregue aos coronéis. Cansada da luta insana, sem glória, a que todos se entregam para amanhecer cada dia mais pobres, enquanto alguns conseguiam enriquecer-se a todo dia. Ela acredita que poderia traçar outros caminhos, inventar uma vida nova. E avançando-se sobre o futuro, Ponciá partiu no trem do outro dia, pois tão cedo a máquina não voltaria ao povoado. (EVARISTO, 2003, p. 33)
\end{abstract}

Ao erigir essa personagem, inscreve-a fora do lugar tradicional da identidade feminina, fixa e presa aos papéis de gênero proclamados pela ideologia patriarcal. Arquiteta uma mulher com perfil transgressor desses papéis, que transita em espaços considerados essencialmente masculinos.

Para além dessa nova perspectiva para o protagonismo negro, Conceição Evaristo marca a colonialidade do poder que exclui o negro dos espaços de autonomia, através da apresentação do sobrenome de Ponciá e de todos os negros que moram na vila Vicêncio:

E era tão doloroso quando grafava o acento. Era como se estivesse lançando sobre si mesma uma lâmina afiada a torturar-lhe o corpo. Ponciá Vicêncio sabia que o sobrenome dela tinha vindo desde antes do avô do avô, o homem que ela havia copiado de sua memória para o barro e que a mãe não gostava de encarar. O pai, a mãe, todos continuavam Vicêncio. Na assinatura dela, a reminiscência do poderio do senhor, de um tal coronel Vicêncio. (EVARISTO, 2003, p. 29).

A narrativa constitui um testemunho de persistência, inventividade humana e ilustração de relatos de resistência. São mulheres e homens negros dominados, que resistem e fazem o melhor que podem para limitar sua exploração e manter sua dignidade. 
Com efeito, a escritora centra sua atenção, especialmente, para configurar as tensões e lutas não visíveis dentro da estrutura social, dedicando-se a criar narrativas que mostram os negros como fomentadores de formas de "resistência cotidiana", como as tratadas por James Scott em "Exploração normal, resistência normal” (2011) em que a resistência cotidiana é informal e dissimulada, preocupada com ganhos imediatos; o sucesso da resistência está ligado à conformidade simbólica com que é dissimulada. Pois "para a maioria das classes subalternas que, de fato, tiveram historicamente escassas possibilidades de melhorar seu status, essa forma de resistência foi a única opção" (SCOTT, 2011, p. 223).

Apropriando-se da linguagem poética em Ponciá Vicêncio, a escritora tanto apresenta a temática do sofrimento e da dor, que se repete na vida do negro a cada geração, como também, as formas de resistência aos moldes de uma lírica próxima da sua poesia:

Depois de ler Ponciá Vicêncio, passei a crer que há uma grande proximidade entre sua poesia e prosa. Se as travessias ontológicas e hermenêuticas dos seus textos narrativos parecem mais suaves do que encontramos na sua poesia, tanto em um como em outro caso, os significados embutidos nas entrelinhas são bastante complexos e acabam nos remetendo às profundas buscas que as personagens fazem de si mesma e ao questionamento do mundo ao seu redor (BARBOSA, 2003, p. 11).

Trata-se de uma narrativa que acena entre o ficcional e o testemunho. A trama parece estar fundamentada na realidade, principalmente quando vista sob a perspectiva do local de voz da autora. É um romance com linguagem própria à procura da consolidação das identidades negras, e uma identificação dos leitores afro-descendentes com esta:

\footnotetext{
Num contexto tão adverso, duas tarefas se impõem: primeiro a de levar ao público a literatura afro-brasileira, fazendo com que o leitor tome contato não apenas com a diversidade dessa produção, mas também com novos modelos identitários propostos para a população afro-descendente; e, segundo, o desafio de dialogar com o horizonte de expectativas do leitor, combatendo o preconceito e inibindo a discriminação sem cair no simplismo muitas vezes maniqueísta do panfleto. (DUARTE, 2008, p. 21).
}

O que encontramos é uma obra que tem como intuito a defesa da entrada do negro nos espaços de letramento e na escrita literária, e busca estabilizar seu espaço de enunciação, de onde podem falar e ouvir sua própria voz.

Isso é evidente nas próprias personagens, ao reclamarem para si uma participação efetiva nas decisões sociopolíticas e a partir disso tentarem uma emancipação intelectual. É o caso de Luandi, irmão de Ponciá Vicêncio: 
Ele, que levara tanto tempo desejando a condição de ser soldado, em poucos minutos escolhia desfazer-se dela. Soldado Nestor, o irmão, não ia concordar com ele. Como explicar para o amigo o que ele acabava de descobrir? Assim como antes acreditava que ser soldado era a única e melhor maneira de ser, tinha feito agora uma nova descoberta. Compreendera que sua vida, um grão de areia lá no fundo do rio, só tomaria corpo, só engrandeceria, se tornasse matéria argamassa de outras vidas. Descobria também que não bastava ler e assinar o nome. Da leitura era preciso tirar outra sabedoria. Era preciso autorizar o texto da própria vida, assim como era preciso ajudar a história dos seus. E que era preciso continuar decifrando nos vestígios do tempo os sentidos de tudo que ficara para trás. E perceber que, por baixo da assinatura do próprio punho, outras letras e marcas havia. (EVARISTO, 2003, p. 127).

Luandi percebe que o baixo nível de letramento é um dos fatores determinantes para demarcar a sua própria classe social e a do seu povo. Ao abandonar o cargo de soldado, adota uma posição subversiva perante o Estado, e assume seu próprio discurso. Essa atitude da personagem denota um ato de resistência à opressão que o negro sofre na sociedade brasileira.

O mesmo ocorre em Becos da Memória com o personagem Negro Alírio. Ainda criança percebe que só poderia ter autonomia para lutar contra os desmandos do Coronel Juvelino se obtivesse o domínio das palavras. A valoração da palavra, como será apresentada no Capítulo III, é uma referência ao real, no caso, à cultura africana:

O homem nascera bem longe dali. Quando criança fora, até um dado momento, um moleque qualquer. Um dia aprendera a ler. A leitura veio aguçar-lhe a observação. E da observação à descoberta, da descoberta à análise, da análise à ação. Ele se tornou um sujeito ativo, muito ativo. Não era um mero observador, um enamorado das coisas e do mundo. Era um operário, um construtor da vida (EVARISTO, 2006, p. 54).

Por se tratar de uma literatura afro-brasileira, definida por Luiza Lobo como a "produção afrodescendente que assumem ideologicamente como tal, utilizando um sujeito de enunciação próprio. Portanto, ela se distinguiria de imediato, da produção literária de autores brancos a respeito do negro, seja enquanto objeto, seja enquanto tema ou personagens estereotipados" (LOBO, 2007, p. 315), Ponciá Vicêncio e Becos da Memória trazem uma modalidade de representação em que, acompanhando as considerações de Roland Barthes sobre a relação entre a literatura e o mundo, a "linguagem do escritor não está encarregada de representar o real, mas de significá-lo... é preciso tratar o realismo do escritor como uma substância ideológica" (BARTHES, 2013, p. 229). O problema não reside na "imitação imperfeita do mundo, mas a invisibilidade de grupos sociais inteiros e o silenciamento de inúmeras perspectivas sociais, como a dos negros" (DALCASTAGNÈ, 2012, p. 89). Nessa visão os romances de Conceição Evaristo mostraram-se relevantes por sua modalidade de representação, a qual possibilita a discussão da problemática da representação literária contemporânea. 
Em Ponciá Vicêncio, encontra-se, sobretudo a voz afrodescendente, que rememora a África - uma África mítica e idealizada, cujas especificidades foram borradas pelo distanciamento geracional da partida e pela violência contra as identidades culturais dos ancestrais -, denuncia as condições de vida dos afro-brasileiros e de forma positiva, firma o sentimento de etnicidade. É uma manifestação literária de resistência à historiografia mítica e idealizada pela literatura canônica, em que o negro é um constante objeto e aparece particularizado de forma a ser sempre um personagem periférico e marginal.

A escolha por uma representação baseada na categoria da representação-efeito e sujeito fraturado coloca os romances de Evaristo na posição de um pensamento deslocado do centro do pensamento dominante, uma vez que a perspectiva da autora é, acompanhando a reivindicação de Mignolo para o que ele denomina "um outro pensamento", "universalmente marginal, fragmentada e suplementar" (MIGNOLO, 2003, p. 104). O uso do sujeito fraturado é a negação de uma identidade homogeneizante estabelecida pela colonialidade do poder. É a aclamação da diversidade das identidades negras e a declaração de que mesmo quem possui uma perspectiva de "escrevivência" não é capaz de apresentá-la em sua plenitude e complexidade. O pensamento liminar é a marca da escrita e das representações de Ponciá Vicêncio e Becos da Memória. 
II

Literatura afro-brasileira: um conceito fraturado 
"A existência de uma literatura afro-brasileira é posterior à existência de uma consciência negra"

(BARBOSA, 1985, p.51)

\subsection{Literatura afro-brasileira: particularização de uma escrita}

"Pode o negro falar? Expressar seu ser e existir negros em prosa e verso? Publicar? Nem sempre". É com essas perguntas e resposta que Eduardo de Assis Duarte (2011, v. I p. 14) inicia sua abordagem sobre a literatura afro-brasileira no primeiro volume da sua antologia crítica sobre o tema. De pronto, o estudo do pesquisador já permite afirmar que, apesar das condições adversas, os negros registraram no passado as chagas da escravidão e hoje continuam a escrever.

O fato é que atualmente o negro possui mais espaço no campo literário para revisar/reconstituir a história, propor/elaborar/apresentar seu ponto de vista, recontar suas condições, sejam elas a do escravo de ontem ou do negro livre, porém proletarizado e marginalizado, de hoje, e outras múltiplas possibilidades de representações sociais (o malandro, o trabalhador, o negro de classe média, etc.). Mas, sobretudo, sempre registrou a saga do negro que resiste às dificuldades de viver numa sociedade feita para homens brancos. Agora, de modo mais sistemático, "o negro já articula uma linguagem literária própria. Rompe o discurso da cultura oficial e se manifesta como um elemento de resistência à sua marginalização social”. Ele está criando "uma cultura literária emergente que expressará esse renascimento do negro" (IANNI, 2011, p. 195).

Cabe reafirmar que essa escrita de homens e mulheres negros não apareceu do nada, assim como nem sempre possuiu visibilidade. Trata-se de uma produção que foi ganhando espaço ao longo do tempo. "Como tema e sistema, ela se desloca aos poucos da história social e cultural brasileira, adquirindo fisionomia própria. Destacando-se da história do povo brasileiro. Desloca-se e desencanta-se pela originalidade e força do movimento social do negro" (IANNI, 2011, p. 194).

Uma literatura forjada e inspirada no movimento social negro; uma escrita que, ao transcender o tempo presente, relembra um passado esquecido, expõe de modo mais claro “as relações entre a Colônia, o Império e a República, lança raízes na África, busca o quilombo e Zumbi, manifesta-se no protesto e na revolta. Neste vasto cenário, atravessando épocas e continentes, emergem o negro, a negritude, a negrícia, o éthos cultural, a comunidade, a nacionalidade afro-brasileira, o povo” (IANNI, 2011, p 194). 
É com base nessa acepção que os romances Ponciá Vicêncio e Becos da Memória, de Conceição Evaristo, acrescentam categoricamente a "esta procura de raízes culturais africanas, esse éthos cultural que nasce dessa busca dramática de reencontro com sua memória cultural africana" (MOURA, 1980, apud IANNI, 2011, p. 195-196).

Assim, de vários modos, as produções romanescas em análise, são constituídas da tentativa de refletir, expressar e organizar uma consciência negra. Ianni (2011) nos traz essa ideia ao afirmar que a literatura, além de expressar, também organiza parte da consciência social do negro; ela é uma forma singular e privilegiada de arranjo da consciência:

\begin{abstract}
A literatura não só expressa como também organiza uma parte importante da consciência social do negro. Ao lado da política, da religião e outras formas de consciência, ela é uma forma singular, privilegiada, de expressão e organização das condições e possibilidades da consciência do negro. Conforme a figuração histórica, a situação social, a conjuntura política, os meios de expressão disponíveis, o horizonte intelectual do escritor, as manifestações da consciência do negro polarizam-se nesta ou naquela direção: fatalismo, e resignação, quilombismo e messianismo, denúncia e crítica social, protesto e revolta. Essas e outras polarizações estão presentes em boa parte da poesia e prosa. E refletem as inquietações, as reivindicações, as buscas de alternativas, o sentimento do mundo, que se espraiam por todos os recantos da vida de indivíduos, famílias, grupos e classes; e atravessa a história da sociedade brasileira (IANNI, 2011, p. 196).
\end{abstract}

É com base nessa perspectiva que este capítulo buscará conceituar a produção literária em que o negro se coloca em evidência, isto é, pretende-se apresentar o conceito de literatura afro-brasileira, sua nomenclatura e refletir sobre a polêmica da autoria, a temática, o ponto de vista, a linguagem e a constituição do universo recepcional dessa literatura em processo de consolidação (DUARTE, 2011). Objetiva-se construir espaços para diversos posicionamentos, mas, apesar de se tratar de uma discussão em processo, também se intenciona apresentar a defesa das abordagens críticas e teóricas consideradas mais adequadas para o termo em questão.

A ideia que se pretende discutir parte da posição de Edmilson de Almeida Pereira em Panorama da literatura afro-brasileira (1995). A partir da declaração de que "a identidade da Literatura Brasileira está ligada a uma tradição fraturada, característica das áreas que passaram pelo processo de colonização", o autor abre caminho para uma sólida compreensão do que seria a literatura afro-brasileira. Isso porque ao sintomatizar a existência da fratura na literatura brasileira, é possível falar em “critério pluralista, estabelecido por uma orientação dialética, que possa demonstrar a Literatura Afro-brasileira como uma das faces da Literatura Brasileira - esta mesma 
devendo ser percebida como uma unidade constituída de diversidades" (PEREIRA, 1995 p. 1).

Essa afirmativa se aproxima das considerações de Duarte (2011), o qual entende a formação da literatura afro-brasileira como alicerçada pelo desvio do padrão, pois a mesma "questiona e abala a trajetória e a linear historiografia literária canônica".

Uma vez que os historiadores da literatura brasileira fecharam os olhos para as produções de escritores afrodescendentes, com pequenas exceções nos casos de Machado de Assis, Lima Barreto e Cruz e Sousa, os quais não são marcados enquanto escritores negros, o trabalho crítico e historiográfico do professor Eduardo de Assis Duarte surge como uma fratura dessa historiografia. Adicionou o que estava fora/silenciado pela historiografia literária, ao resgatar escritores precursores como Maria Firmina dos Reis, Luiz Gama, Lino Guedes, Auta de Souza, Solano Trindade, Carolina Maria de Jesus... E os mais contemporâneos como Cidinha da Silva, Cristiane Sobral, Ana Maria Gonçalves, Márcio Barbosa, Paulo Lins, Conceição Evaristo, entre outros.

Duarte (2011) entende a literatura afro-brasileira como uma literatura suplementar ${ }^{6}$, aquela que só está dentro da literatura brasileira porque faz uso da mesma língua e dos seus processos de expressão, mas que está fora do projeto literário brasileiro, a qual tem como papel ideológico a construção do nacional, ou seja, tem a missão de criar uma literatura brasileira e de construir uma nação.

O que ocorre é que essa literatura suplementar tem o seu próprio projeto, o de erigir uma escritura produzida por afrodescendentes, que se destaca pela denúncia ao etnocentrismo que exclui a escrita do negro e a lança à margem do cânone. Ela

\footnotetext{
6 "O conceito de suplemento - que aqui determina o de imagem representativa - abriga nele duas significações cuja coabitação é tão estranha quanto necessária. O suplemento acrescenta-se, é um excesso, uma plenitude enriquecendo uma outra plenitude, a culminação da presença. Ele cumula e acumula a presença. É assim que a arte, a tekhné, a imagem, a representação, a convenção etc., vem como suplemento da natureza e são ricas de toda esta função de culminação. Esta espécie da suplementariedade determina, de uma certa maneira todas as oposições conceituais nas quais Rousseau inscreve a noção de natureza na medida em que deveria bastar-se a si mesma.

Mas o suplemento supre. Ele não se acrescenta senão para substituir. Intervém ou se insinua em-lugar-de; se ele colma, é como se cumula um vazio. Se ele representa e faz imagem, é pela falta anterior de uma presença. Suplente e vicário, o suplemento é um adjunto, uma instância subalterna que substitui. Enquanto substituto, não se acrescenta simplesmente à positividade de uma presença, não produz nenhum relevo, seu lugar é assinalado na estrutura pela marca de um vazio. Em alguma parte, alguma coisa não pode-se preencher de si mesma, não pode efetivar-se a não ser deixando-se colmar por signo e procuração. O signo é sempre o suplemento da própria coisa... Acrescentando-se ou substituindo-se, o suplemento é exterior, fora da positividade à qual se ajunta estranho ao que, para ser por ele substituído, deve ser distinto dele. Diferentemente do complemento, afirmam os dicionários, o suplemento é uma "adição exterior"... O suplemento é a imagem e a representação da natureza. Ora, a Imagem não está nem dentro nem fora da natureza. Portanto, o suplemento também é perigoso para a razão, para a saúde natural da razão" (DERRIDA, 1973, p. 177/178/183).
} 
apresenta-se como protesto contra as representações feitas sobre o negro na literatura brasileira, em nome de um sentido de verossimilhança baseado em suas experiências. Em suma, a literatura afro-brasileira fratura o projeto romântico da literatura brasileira; enquanto diversidade ela não busca complementar a literatura brasileira, mas juntar-se a ela:

\begin{abstract}
Assim temos uma produção que está dentro da literatura brasileira, porque se utiliza da mesma língua e, praticamente, das mesmas formas, gêneros e processos (procedimentos) de expressão. Mas que está fora porque, entre outros fatores não se enquadram na "missão" romântica, tão bem detectada por Antonio Candido, de instituir o advento do espírito nacional. Uma literatura empenhada, sim, mas num projeto suplementar (no sentido derridiano) ao da literatura brasileira canônica: o de edificar, no âmbito da cultura letrada produzida pelos afrodescendentes, uma escritura que seja não apenas a sua expressão enquanto sujeitos de cultura e de arte, mas que aponte o etnocentrismo que os exclui do mundo das letras e da própria civilização. Daí seu caráter muitas vezes marginal, porque fundado na diferença que questiona e abala a trajetória e a linear historiografia literária canônica. (DUARTE, 2008, p. 22).
\end{abstract}

A problematização da historiografia literária brasileira, na visão de Cuti (2010) está atrelada ao aparecimento de leitores negros, autores e personagens, os quais trouxeram "a incorporação dos elementos culturais de origem africana no que diz respeito a temas e formas, traços de uma subjetividade coletiva fundamentados no sujeito étnico do discurso, mudanças de paradigmas crítico-literário, noções classificatórias e conceituais das obras de poesia e ficção" (CUTI, 2010, p. 11). É possível também falar em uma crítica com essas características, que junto ao Movimento Negro Unificado - MNU, de 1978, também foi importante para que "a vertente da literatura negra brasileira se descongele da omissão ou do receio de dizer sua subjetividade" (CUTI, 2010, p. 28).

Enquanto Duarte (2011) chama esse fenômeno de surgimento de uma literatura suplementar, na mesma ideia de suplemento ou adição, Cuti (2010) chama de "veio da literatura brasileira", ou seja, a literatura negro-brasileira ${ }^{7}$ é um dos aspectos ou face da brasileira, como abordou Pereira (1995).

Por considerar a minimização das conquistas da população "negro-brasileira" e o projeto de nação brasileira exclusivamente branca é que esse "veio da literatura brasileira" foi se constituindo como denúncia da exclusão do negro enquanto cidadão brasileiro, ao pronunciar-se sobre a exigência de uma inclusão na nação brasileira. "A literatura negro-brasileira do sussurro ao grito vem alertando para isso, ao buscar seus

\footnotetext{
7 As questões referentes às diferenças nas nomenclaturas que definem a literatura de autoria negra serão abordadas em outra sessão deste capítulo, de antemão cabe dizer que nesta pesquisa optou-se pelo uso da expressão "literatura afro-brasileira" utilizada especialmente por Duarte (2011).
} 
próprios recursos formais e sugerir a necessidade de mudanças de paradigmas estéticoideológicos" (CUTI, 2010, p.12) em detrimento das formas europeias, tão consagradas. Portanto, a dificuldade de estabelecer visibilidade a esse veio literário ocorre justamente porque a literatura negro-brasileira sugere uma rasura e transbordamento da estética literária em vigor.

Cuti (2010) faz um panorama do modo como vinha ocorrendo a representação caricatural do negro na literatura canônica, antes dessa proposta de rasura da literatura afro-brasileira. Com o exemplo do texto de Nelson Rodrigues, publicado em um artigo na imprensa brasileira, no ano de 1957, Cuti explica, por meio do texto do cronista, como o negro foi usado enquanto objeto da crítica:

\footnotetext{
Não caçamos pretos, no meio da rua, a pauladas, como nos Estados Unidos. Mas fazemos o que talvez seja pior. A vida do preto brasileiro é toda tecida de humilhações. Nós o tratamos com uma cordialidade que é o disfarce pusilânime de um desprezo que fomenta em nós dia e noite. Acho o branco brasileiro um dos mais racistas do mundo (RODRIGUES apud CUTI, 2010, p.19).
}

Numa leitura rápida e sem muita reflexão, o texto de Nelson Rodrigues parece fazer um discurso representativo do negro, principalmente pela menção do termo "preto (s)", o que parece se tratar de dar visibilidade a um grupo marginalizado e de fazer uma denúncia do sofrimento vivenciado por esses. Mas, na verdade, ao fazer uma autocrítica a respeito do preconceito racial, Nelson Rodrigues acaba por criar "um sujeito étnico branco, pois escreve sobre o 'preto' para outro branco, formando com este último um "nós" branco. Nesse caso, o negro é objeto da autocrítica, é a respeito dele que se escreve. Não é o negro que dirige a palavra nem é a ele que a palavra é dirigida" (CUTI, 2010 , p. 20). A licença para falar e ouvir é dada apenas ao branco, nem o direito de confirmar essa representatividade é dado ao negro.

O texto de Nelson Rodrigues sinaliza a ideologia racista da ilegitimidade do negro discutir suas próprias questões ou problemáticas, ao passo que privilegia esse poder de fala do branco, de modo que o racismo estrutural e a simulação do discurso da “democracia racial” são instituídos no texto. Mesmo denunciando o racismo, está implícito que o negro é colocado como o diferente do branco, o "outro", numa representatividade negativa, no sentido de inferioridade, aquele que não pode ser autor de sua história, que não pode ser o destinatário de sua própria epopeia, que não tem relação de interlocução no texto, apenas é o tema, o objeto usado pelos brancos para fingirem a democracia racial, portanto trata-se de um racismo à brasileira. Com isso, não se objetiva tirar o caráter transgressor desse texto considerando o contexto da época, 
mas apontar as falhas nas formas discursivas de representação do negro e os discursos racistas abafados.

Em contraponto ao texto do dramaturgo Nelson Rodrigues, em que o "nós branco" é forjado, Cuti apresenta o texto do poeta negro Luiz Gama publicado em 1859 no livro Primeiras Trovas Burlescas de Getulino:

\author{
Desculpa, meu amigo \\ Eu nada te posso dar \\ $\mathrm{Na}$ terra que rege o branco \\ Nos privam até de pensar. \\ Ao peso do cativeiro \\ Perdemos razão e tino, \\ Sofremos barbaridades \\ Em nome do Ser Divino!! \\ (CUTI, 2010, p. 19)
}

Nos versos de Luiz Gama não há o recuo da "abstração" da identidade negra, como no texto de Nelson Rodrigues, pois a identidade do negro é mantida até o final. Ele não só apresenta o sujeito étnico negro como também dirige o texto a ele, ou seja, há uma construção imaginária de um "nós negro" fomentada por um eu anunciador e receptores advindos de uma mesma "base de identidade biossocial", no caso, o povo negro. Embora a expressão "negro" não apareça no texto, o contexto "intra e extratexto" aponta para o sujeito negro. Ambos os textos têm em comum apenas o fato de afirmarem a existência do racismo.

A representação do negro, no poema "Negros" de Solano Trindade (2008) segue a proposta de afirmação da identidade negra, assim como foi apresentada por Luiz Gama, no entanto, diferencia-se dele ao apresentar uma identidade negra imbricada de complexidade:

\title{
NEGROS
}

Negros que escravizam E vendem negros na África

Não são meus irmãos

Negros senhores na América

A serviço do capital

Não são meus irmãos

Negros opressores

Em qualquer parte do mundo

Não são meus irmãos

Só os negros oprimidos

Escravizados

Em luta por liberdade

São meus irmãos 
Para estes tenho um poema

Grande como o Nilo

(TRINDADE, 2008, p. 41)

Trindade não só apresenta o negro vitimado, mas também aquele que vitima os seus. O texto se mostra rico ao evidenciar a subjetividade do negro, que não só pode escolher por lutar pela liberdade de uma coletividade, mas pode desviar-se do ideal grupal e alçar-se aos opressores. O poema não se limita a denunciar os "não-irmãos", vai além, ao explorar as diferentes identidades do negro com fim de ressaltar a sua humanidade.

Ainda sobre o antigo panorama da representação do negro, Cuti descreve o processo de eliminação/abstração da personagem negra nas narrativas brasileiras: a eliminação "passa a ser um levado código de princípios. Ou a personagem morre, ou sua descendência clareia. A evolução do negro no plano da ficção só pode ocorrer no sentido de se tornar branco, pois a "afro-brasilidade" pode sobreviver sem o negro" (CUTI, 2010, p. 34-35). Em contraponto a tudo isso, a literatura afro-brasileira vem demarcar "o ponto diferenciado de emanação do discurso, o "lugar" de onde fala" (CUTI, 2010, p. 25). Sobre esse aspecto, Luiza Lobo define:

\footnotetext{
O principal aspecto que indica uma mudança significativa entre os estudos sobre o negro realizados no passado e os que apareceram nesta década de 1980 é o fato de que o negro deixa de ser objeto e passa a sujeito da literatura e da própria história; deixa de ser tema (inclusive como estereótipo) para ser autor, com uma visão de mundo própria. Assim poderíamos definir literatura afro-brasileira como a produção literária de afro-descendentes que se assumem ideologicamente como tal, utilizando um sujeito de enunciação próprio. Portanto, ela se distinguiria, de imediato, da produção literária de autores brancos a respeito do negro, seja enquanto objeto, seja enquanto tema ou personagem estereotipado (LOBO, 2007, p. 315).
}

$\mathrm{Na}$ categoria personagens, o estilo de Conceição Evaristo é o "expurgo dos estereótipos", marcado especialmente na construção das personagens infantis. Como será explicado no próximo capítulo, essa escolha sinaliza a conscientização crítica social a respeito da criança negra brasileira.

De modo panorâmico, essa literatura problematiza o discurso colonial que se volta para o apagamento da história e da cultura que ultrapassa os limites de uma tradição dominante e branca. Para justificar a especificidade e o desvio da literatura canônica, resumidamente, Duarte (2011) apresenta a temática, a autoria, o ponto de vista, a linguagem e o público como os elementos identificadores da literatura afrobrasileira: 
Para além das discussões, alguns elementos identificadores podem ser destacados: uma voz autoral afrodescendente, explícita ou não no discurso; temas afro-brasileiros; construções linguísticas marcadas por uma afrobrasilidade de tom, ritmo, sintaxe ou sentido; um projeto de transitividade discursiva, explícito ou não, com vistas ao universo recepcional; mas, sobretudo, um ponto de vista ou um lugar de enunciação política e culturalmente identificado à afrodescendência, como fim e começo (DUARTE, 2011, p. 385).

Influenciado pela concepção de Octávio Ianni (1988), Duarte (2011) pontua que o negro ou o sujeito afrodescendente deve ser abordado na literatura afro-brasileira não apenas como "sujeito afrodescendente, no plano do indivíduo", mas também é preciso aparecer o sujeito como "universo humano, social, cultural e artístico de que se nutre essa literatura" (IANNI, 1988, p. 209). É desse modo que o afrodescendente deve ser apresentado enquanto tema. O tema, portanto, "é um dos fatores que ajuda a configurar o pertencimento de um texto à literatura afro-brasileira”.

A escolha por essa temática é justificada pela objetividade desse projeto literário, "o resgate da história do povo negro na diáspora brasileira, passando pela denúncia da escravidão e de suas consequências, ou ir à glorificação de heróis como Zumbi dos Palmares" (DUARTE, 2011, p. 386). Além de apresentar esse sujeito do modo mais amplo possível, a literatura afro-brasileira traz também as tradições culturais, como a religião, o mito, a lenda e o imaginário dessa cultura abarcado também pela oralidade. Os textos como os de Conceição Evaristo são atravessados pela "recuperação de uma multifacetada memória ancestral", a qual fundamenta o processo de identificação das personagens negras, além da presença de elementos rituais e religiosos. Há também na ficção contemporânea o registro dos espaços ocupados pelos negros da sociedade brasileira. O subúrbio e a favela são colocados em cena para trazer ao leitor os problemas como a exclusão, a miséria, a fome, o preconceito, o branqueamento, a marginalidade e a prisão (DUARTE, 2011).

Depois dessas considerações é preciso acrescentar que Duarte (2011) é flexível ao sobrepor a não exigência totalitária de uma temática que fala das condições de existência passadas e presentes dos afro-brasileiros, pois tal postura funcionaria como limitação ao artista e consequentemente ofereceria riscos de empobrecimento à obra. Também não condiciona a temática da negritude como algo que deva ser apenas apreendido pelos afrodescendentes, nada impede que ela seja a escolha de um autor branco. Então, a escolha da "temática afro não deve ser considerada isoladamente e, sim, com outros fatores como autoria e ponto de vista” (DUARTE, 2011, p. 387). 
Outro ponto relacional ao elemento identificador da literatura afro-brasileira é "a autoria", a mais polêmica e questionável das propostas apresentadas por Duarte. Embora esse conceito de autoria pareça insinuar a ideia de "fatores biográficos e fenótipos" o entendimento de afrodescendência, defendido por Duarte (DUARTE, 2011, p. 388) vai além de uma ideia de descendência racial ou biológica é "muito mais a uma construção identitária, no sentido em que a questão das identidades é trabalhada pelo pensamento contemporâneo - Bhabha, Spivak, Said, Hall e outros" (DUARTE, 2011, p.33). Nesse sentido a afrodescendência do autor está relacionada à construção identitária.

Duarte (2011) avalia que a abertura para a consideração de uma literatura afrobrasileira de autoria branca implica em um possível reducionismo temático dessa produção ao "negrismo, entendido como utilização, por quem quer que seja, de assuntos atinentes aos negros". O autor traz a problemática de que enquanto não se pode enquadrar Castro Alves (poeta dos escravos) na literatura afro-brasileira, escritores afrodescendentes como Marilene Felinto não reivindicam para si a condição de escritor afro-brasileiro nem a incluem em seu projeto literário.

O crítico conclui que tal fenômeno alerta para o cuidado de não condicionar a criação e a crítica literária a fatores puramente sociológicos, isso significa dizer que é perigoso buscar a compreensão do texto a partir de fatores externos (cor da pele e condição social). A autoria deve ser compreendida como uma "constante discursiva integrada à materialidade da construção literária", ou seja, o texto deve evidenciar o local de voz autoral e não o autor explicar a obra. Do mesmo modo, Lobo (2007, p. 253254) - entende que "não é simplesmente a cor da pele que define a literatura negra. É preciso, além desta, uma convicção ideológica na narração do autor que corrobore, através de um sujeito de enunciação que expressa a identidade com a negritude".

Em suma, para Duarte (2011) a autoria configura-se como elemento indispensável para a definição da literatura afro-brasileira em decorrência da importância dada à influência mútua entre "escritura e experiência". Essa interação autoral versus a experiência de ser negro na sociedade brasileira é adotada por alguns autores a partir de "compromisso identitário e comunitário", ou pode se tratar de uma “formação de artista da palavra”. Há aí uma tendência do artista se ver como um portavoz da sua comunidade, logo que o fazer literário do escritor afro-brasileiro restaura a tradição africana dos griots. $^{8}$

\footnotetext{
${ }^{8}$ O próximo capítulo irá explicitar as ideias que envolvem a figura do griot na literatura afro-brasileira e mais especificamente nos romances de Conceição Evaristo.
} 
Duarte termina suas considerações acerca da "autoria" elucidando as marcas autobiográficas e o testemunho ou precisamente a "interação escritura e experiência" (DUARTE, 2011, p. 389) como elementos presentes na escrita de vários escritores, mas o destaque é dado a Conceição Evaristo, que assume e "reivindica para seus textos o estatuto de escrevivência". Como bem dizem as passagens de seu texto Da grafiadesenho de minha mãe, um dos lugares de nascimento da minha escrita (2007):

\begin{abstract}
$\mathrm{Na}$ origem da minha escrita ouço os gritos, os chamados das vizinhas debruçadas sobre as janelas, ou nos vãos das portas contando em voz alta uma para outras as suas mazelas, assim como as suas alegrias. Como ouvi conversas de mulheres!... creio que a gênese de minha escrita está no acúmulo de tudo que ouvi desde a infância. O acúmulo das palavras, das histórias que habitavam em nossa casa e adjacências. Dos fatos contados a meia-voz, dos relatos da noite, segredos, histórias que as crianças não podiam ouvir. Eu fechava os olhos fingindo dormir e acordava todos os meus sentidos. O meu corpo por inteiro recebia palavras, sons, murmúrios, vozes entrecortadas de gozo ou dor dependendo do enredo das histórias. De olhos cerrados eu construía as faces de minhas personagens reais e falantes. Era um jogo de escrever no escuro (EVARISTO, 2007, p. 19).
\end{abstract}

Do mesmo modo que a temática não pode estar dissociada da autoria, a autoria também deve ser associada ao ponto de vista, e nesse caso leva-se em consideração que a literatura é discurso e a cor da pele de um autor só será importante "enquanto tradução textual de uma história própria e coletiva" (DUARTE, 2011, p. 390).

O "ponto de vista" autoral é o terceiro elemento apontado por Duarte (2011) para compor a especificidade da literatura afro-brasileira. Ele é o indicativo do espaço de fala do autor, dos aspectos axiológicos ou da dimensão axiológica verificável no texto e da escolha do vocabulário para figurar do negro. Assim não é possível enquadrar um texto, nessa literatura, considerando apenas a ascendência africana ou mesmo a utilização do negro como tema. "É necessário ainda a assunção de uma perspectiva identificada à história, à cultura, logo, toda problemática inerente à vida e às condições de existência desse importante segmento da população" (DUARTE, 2011, p. 391).

Segundo Duarte, o ponto culminante da tomada do ponto de vista na literatura afro-brasileira ocorre com a série Cadernos Negros. Seus produtores assumem uma ruptura com a estética vigente, declaram a vez e a voz de uma África esquecida e oprimida pela brancura, e assumem de vez a "negrura bela e forte". E é com a ideia do renascer das cinzas que os escritores dos Cadernos Negros tomam para si um discurso próprio, suplantam estéticas diferentes dos modelos europeus, superam a assimilação e o discurso do colonizador. De modo que "a perspectiva afro-identificada configura-se enquanto discurso da diferença e atua como elo importante dessa cadeia discursiva" (DUARTE, 2011, p. 394). 
A linguagem também se constitui como fator de caracterização da literatura em questão. "A linguagem é, sem dúvida, um dos fatores instituintes da diferença cultural no texto literário. Assim, a afro-brasilidade tornar-se-á visível, também a partir de um vocabulário pertencente às práticas linguísticas oriundas de África e inseridas no processo transculturador em curso no Brasil” (DUARTE, 2011, p. 394). O crítico complementa ao dizer que se trata de uma literatura com ritmos, entonação e semântica particular que por vezes desempenha o papel de "ressignificação", que incomoda as normas hegemônicas da língua.

Esse rompimento com o discurso colonial significa a trama de projetar "uma nova ordem simbólica" capaz de externar uma "reversão de valores" (BERND, 1988, p. 109-110). Isso seria a busca de uma "reterritorialização" da cultura negra e a reversão do discurso hegemônico. Os tons de negatividade das palavras relacionadas à cultura ou ao mundo do negro ganham um viés de positividade. "Assim, a assunção de uma linguagem descomprometida com os "contratos de fala" dominantes ganham sentido político" (DUARTE, 2011, p. 397).

Por fim, a formação de um "público" leitor, a preocupação de um público específico, o cuidado com o "horizonte recepcional afrodescendente" é, também, um elemento diferenciador da literatura afro-brasileira. A ideia não é apenas produzir uma literatura que fale do negro, mas também que fale para o negro. E para alcançar esse público, os escritores usam estratégias de divulgação não convencionais, eles vão onde o público está, seja em saraus da periferia, eventos acadêmicos ou rodas de rap.

O projeto parece utópico, por se tratar de uma intervenção num campo tão complexo como o da formação do hábito e gosto pela leitura e ainda mais de um público negro que em sua maioria é de classe social baixa. Portanto, as duas missões a que esses escritores se prestam são a de levar ao público a literatura afro-brasileira, objetivando que o leitor ao conhecer essas produções, tenha uma identificação com o novo modelo de representação da identidade negra; e também, "o desafio de dialogar com o horizonte de expectativas do leitor, combatendo o preconceito e inibindo a discriminação sem cair no simplismo muitas vezes maniqueísta do panfleto" (DUARTE, 2011, p. 398).

Na visão de Duarte a interação desses cinco fatores: temática, autoria, ponto de vista, linguagem e público é o que legitima e confirma a existência da literatura afrobrasileira. Para ele esses elementos aparecem como uma constante discursiva, o que os assinala como "critérios diferenciadores e pressupostos teórico-críticos" para fundamentar a leitura e análise dessa produção. O que significa dizer que o modo como 
se fará a leitura de um texto afro segue a base dessas características. Assim, fica claro que a literatura afro-brasileira não se distingue da literatura brasileira apenas pela sua missão e características, mas também pelo próprio método de apropriação da obra.

Títulos como Axé, Cadernos Negros e Quilombo de Palavras, são exemplos de produções que assumiram uma escrita de ruptura com a literatura brasileira e garantiram o direito a seus textos de serem chamados afro-brasileiros. "O fato de assumirem essa nomeação, conscientemente, pode ser interpretado como um sinal de que os negros estão querendo criar a si mesmos e que uma das etapas deste processo seria justamente a de particularizar sua escritura, dando-lhe feição própria” (BERND, 1988, p. 21).

Em se tratando de publicações individuais, Conceição Evaristo está entre os escritores que explicitam e celebram seus vínculos étnicos e culturais com a herança africana. A autora assume explicitamente um projeto literário afro-brasileiro, apresenta traços discursivos que a situam na órbita de valores socioculturais distintos dos abraçados pelas elites brancas. Ela expressa valores transformando-os em linguagem literária, está inserida em um grupo de "autores cuja produção se distingue no panorama literário da segunda metade do século, e que já pode ser classificada como afrobrasileira, pois apresenta temas, linguagem e, sobretudo, pontos de vista marcados pelo pertencimento étnico e pelo propósito de construir um texto afro-identificado" (DUARTE, 2011, v. 1, p. 37).

\section{2 "A arte não cabe em definições": literatura negra, negro-brasileira ou afro- brasileira?}

A literatura feita para negros com temática negra e com personagens negros recebe não só definições diferentes, como as apresentadas até aqui, e as demais ao longo desse capítulo, mas também, nomenclaturas diferenciadas. Em Duarte (2011) e nas críticas Florentina de Sousa e Maria Nazaré Lima (2006) aparece a mais utilizada na atualidade pelos pesquisadores, "Literatura Afro-brasileira"; já Octávio Ianni (2011) e Zilá Bernd (1988) optam pelo uso de "Literatura Negra" e para o também crítico e escritor Cuti (2010) observa-se a escolha pelo termo "Literatura Negro-brasileira". Vale dizer mais uma vez, que nesta pesquisa, por razões de posicionamento epistemológico, optou-se pelo uso do termo "literatura afro-brasileira", no entanto as três nomenclaturas serão apresentadas ao longo do capítulo. 
Para propor uma nomenclatura ideal é interessante pensar nas reflexões de Cuti em entrevista concedida a Duarte (2011): "Não considero tão importantes as definições de literatura. Todas elas serão cambiantes. A arte não cabe em definições. Extrapola, deslimita" (CUTI, 2011, p. 45). De modo que, embora se opte por uma denominação, é sabido que todo nome traz limitações e reducionismos, apesar de algumas serem consideradas mais adequadas.

Apesar do tom ameno em relação à nomeação de uma literatura suplementar, Cuti diz que a nomenclatura "afro-brasileira" não é tão abrangente ou rica, além de ser menos engajada que "Literatura negra", pois esse termo carrega o "negro" que possui muito mais conotações. "Parece uma questão de tom, mas não é apenas isso. A palavra 'negro' é muito mais polissêmica e contundente. 'Afro-brasileiro' é um termo apaziguado de conflitos, lembra conceito forjado em gabinete. Muito menos rico que aquele" (CUTI, 2011, p. 60). Para Cuti, apesar de parecer ser um termo abrangente, tem uma ideia de inclusão que na verdade fragiliza a identidade textual e a folcloriza, à moda modernista, além de banalizar as lutas dos descendentes africanos, ou seja, possui uma inadequação ideológica:

Incluir pessoas que se recusaram e recusam a identidade negra em um
conjunto que afirma e reafirma essa identidade parece-me uma estratégia
inadequada. Se, por um lado, aumenta o número de escritores, e,
consequentemente, uma certa respeitabilidade (quem não quer incluir um
Mário de Andrade, um Machado de Assis, um Jorge de Lima, uma vez que
são autores de renome), por outro fragiliza a identidade textual, além de ser,
também, um aval para o veio folclorizante do tipo modernista, que deitou
profundas raízes na produção cultural brasileira, além de banalizar toda a
saga da descendência africana, escamoteando os conflitos que dela fizeram e
fazem parte até hoje. O sentido de amplitude que a expressão "afro-
brasileira" possa ter é caracterizado pela conotação dissolvente da identidade
negra (CUTI, 2011, p. 62).

Então, nesse parecer, o termo "afro-brasileiro" é visto como uma tentativa de amenizar o possível desequilíbrio ou conflitos que o termo "negro" pode gerar em uma sociedade, que simula uma democracia racial. Cuti acredita que a escolha desse conceito ameno esconde uma "guerra sem testemunha"... "Veja, um afro-brasileiro não necessita ser necessariamente negro. Ele pode ser mestiço ou branco, o que em certa medida é o mesmo. A polarização criativa perde seu impulso, a crítica ao racismo também. A renúncia à branquitude perde seu sentido" (CUTI, 2011, p. 60). A postura de Cuti soa muito dura, excludente e não considera o contexto de produção de alguns escritores, deslegitima também outros contextos de militância de autores como Machado de Assis. O exagero da crítica ao termo "afro-brasileira" é percebido, ainda, quando Cuti revela seu apego à vinculação do prefixo "afro" ao continente Africano: 
Denominar de afro a produção literária negro-brasileira (dos que assumem como negros em seus textos) é projetá-la à origem continental de seus autores, deixando-a à margem da literatura brasileira, atribuindo-lhe, principalmente, uma desqualificação com base no viés da hierarquização das culturas, noção bastante disseminada na concepção de Brasil por seus intelectuais. "afro-brasileiro" e "afrodescendente" são expressões que induzem a discreto retorno a África, afastamento silencioso do âmbito da literatura brasileira para se fazer de uma vertente negra, um mero apêndice da literatura africana (CUTI, 2010, p. 36).

As considerações de Cuti carregam o purismo etimológico que desconsidera a apropriação do prefixo, já feita no português do Brasil, para se referir a um contexto mais amplo, mas que também inclui a negritude. Parece não ser compreensível para Cuti o fato do prefixo "afro" fazer referência aos deslocamentos de vários povos africanos no Brasil e aparentemente esquece que a diáspora africana permitiu que esse termo passasse a carregar também essa carga semântica que está ligada e, ao mesmo tempo em que está destacada/deslocada da África, reapropriada, ressituada em outros contextos culturais e nacionais, no caso o contexto brasileiro. Desse modo, o uso do prefixo "afro" não pode funcionar como um silenciamento dessa literatura suplementar, muito menos possuir um caráter de minimizá-la em relação à literatura brasileira, nem a mesma configura-se como apêndice das literaturas africanas.

$\mathrm{O}$ autor acredita que atrelar a produção negro-brasileira aos termos "afrobrasileira" e "afrodescendente" é supostamente fazer da literatura brasileira de vertente negra um "mero apêndice da literatura africana", o que pressupõe que apenas autores brancos pudessem fazer literatura brasileira, portanto, na visão do crítico, a escolha do termo afro explicita o afastamento silencioso da literatura negro-brasileira em relação à literatura brasileira.

Além dessas questões controversas apresentadas como problemáticas, Cuti acrescenta mais equívocos ao dizer que o uso do termo "afro" também pode soar como reducionismo da literatura africana, haja vista, a complexidade de cada sistema literário apresentado nesse continente, bem como o soar da negação das singularidades nacionais, com finalidades comerciais:

Atrelar a literatura negro-brasileira à literatura africana teria um efeito de referendar o não questionamento da realidade brasileira por esta última. A literatura africana não combate o racismo brasileiro. E não se assume como negra. Ainda a continentalização africana da literatura é um processo desigual se compararmos com outros continentes. Países com a sua singularidade estético-literária são colocados sob um mesmo rótulo. A diversidade africana mais uma vez é negada. Como um navio tumbeiro literário são misturadas as literaturas para venda em outras partes do mundo. Essa negação das singularidades nacionais enfatiza ainda a dominação global, com roupagem de um tráfico, agora de livros. Africanos de hoje, em particular os literatos, ciosos da busca de reconhecimento cultural de suas nacionalidades, incluindo 
aí os africanos brancos, tendem a rejeitar uma identidade continental para suas obras, preferindo a caracterização nacional baseada na noção territorial geográfica (CUTI, 2010, p. 36 e 37).

A escolha de outro termo, contendo o substantivo "negro", é para o crítico uma forma de resguardar a noção de negritude, que "é a dimensão do ser-negro- no- mundo". Considerando o fato de que ainda hoje, os negros são "hostilizados em qualquer parte do mundo, não podemos perder essa dimensão mais ampla da nossa identidade negra, pois isso nos fortalece e conforta” (DUARTE, 2011, p. 60). Ele entende que essa opção é a ideal, porque a presença da palavra negro "amplia o horizonte da identidade textual da nossa literatura, pois não tergiversa." (DUARTE, 2011, p. 61).

Sua posição difere da de Eduardo de Assis Duarte (2011), que pensa o termo literatura afro-brasileira como o mais adequado por ser abrangente e menos militante contemplando, nesse sentido, mais a pesquisa e o ensino, além de abranger a produção dos escritores que não assumiram uma postura política explícita quanto à questão étnica e racial no Brasil, como no caso das produções machadianas. O uso do termo de Cuti, por incluir o termo "negro", pode soar como exacerbadamente "militante" o que deve refletir na avaliação da qualificação do texto, já que o mesmo remete à expressão "engajada", que supostamente traria a ideia de pouca preocupação com o estético.

Duarte tem o respaldo de Souza e Lima (2006) na defesa do termo "literatura afro-brasileira", haja vista as possibilidades de maior inclusão de autores que não explicitaram em suas escritas a denúncia ao racismo ou a resistência negra. A defesa é justificada com a afirmação de que a literatura é um trabalho com linguagem e não precisa ser pensada como o puro reflexo do mundo:

\footnotetext{
Nessas criações, nem sempre a denúncia da exclusão é direta, e, em algumas delas, a questão nem mesmo aparece. Essa celebração da presença africana em rituais preservados pela cultura brasileira está também na obra de alguns autores afro-descendentes. Esses últimos defendem que tanto os mecanismos de preconceito e exclusão quanto à resistência a esses mesmos mecanismos não precisam ser tratados de forma explícita na produção artística. Literatura, dizem muitos escritores, é um trabalho de linguagem e não pode ser pensada como puro reflexo do mundo em que vivemos (SOUZA e LIMA, 2006, p. 37).
}

Vale trazer as ideias postuladas por Maria Nazareth Soares Fonseca em Literatura Negra, Literatura Afro-brasileira: como responder a polêmica? (2006). A escolha do título do artigo não deixa evidente a preferência da autora pelo uso da nomenclatura "afro-brasileira", mas suas explanações encaminham para tal conclusão. A riqueza das discussões tecidas se dá pelo método de apresentar as ideologias inscritas

\footnotetext{
${ }^{9}$ No sentido de ser panfletária.
} 
tanto no termo "literatura negra" como em "literatura afro-brasileira". Nas diferenciações apontadas ficam evidentes os motivos da escolha da autora.

Sobre a denominação "literatura negra" Maria Nazareth Soares Fonseca Lima diz que a palavra está atrelada à busca de uma integração "às lutas pela conscientização da população negra, busca dar sentido a processos de formação da identidade de grupos excluídos do modelo social pensado por nossa sociedade. Nesse percurso se fortalece a reversão das imagens negativas que o termo "negro" assumiu ao longo da história" (FONSECA, 2006, p. 23-24).

Do mesmo modo que Duarte (2011), Fonseca (2006) aposta na nomenclatura afro-brasileira como uma expressão que explica melhor o conceito de literatura suplementar. A autora considera que ela é mais rica em sentidos, pois "procura assumir as ligações entre o ato criativo que o termo 'literatura' indica e a relação dessa criação com a África, seja aquela que nos legou a imensidão de escravos trazida para as Américas, seja a África venerada como berço da civilização" (FONSECA, 2006, p. 24). Em suma, as escritoras entendem que a expressão "afro-brasileira" tem se mostrado mais contundente porque não limita às complexas questões que orbitam em torno de seus significados, ao passo que revelam a pluralidade como um traço importante da cultura brasileira (FONSECA, 2006, p. 38), enquanto o termo literatura negra restringe por insinuar aspectos mais políticos e menos literários:

\footnotetext{
Nesse sentido, a expressão "literatura afro-brasileira" parece seguir uma tendência que se fortalece com o advento dos estudos culturais. O uso de expressões como "afro-brasileiro" e "afrodescendente" procura diluir o essencialismo contido na expressão "literatura negra" e transpor a dificuldade de se caracterizar essa literatura sem assumir as complexas discussões suscitadas pelo movimento da Negritude em outro momento histórico (FONSECA, 2006, p. 23-24).
}

Assim, é preferível a nomenclatura "literatura afro-brasileira", pois ela não pressupõe a rigidez posta por Cuti (2011), além de permitir, como bem foi colocado por Ianni (2011), que autores como Machado de Assis se libertem das leituras eurocêntricas impostas às suas obras. Logo, Cuti (2010), que combate a autocensura dos textos produzidos majoritariamente pela descendência africana no Brasil, acaba por censurar alguns escritores precursores, por achar que a manifestação literária reivindicatória só pode apoiar-se na palavra "negro". 


\subsection{Tendências e perspectivas fraturadas: "O eu-sujeito a criar um texto"}

Ao ser questionada por Duarte (2011) sobre os elementos constituintes da literatura afro-brasileira e sua diferença da literatura tout court, Conceição Evaristo apresenta como elementos indispensáveis de um discurso literário afro-brasileiro a declaração explícita no texto ou na estética do texto de um pertencimento étnico; a presença de uma ancestralidade africana; a fuga da cópia eurocêntrica em função de um contradiscurso; a revisão histórica do passado de escravidão dos africanos e seus descendentes no Brasil; denúncia contra o racismo e as injustiças sociais; e o elemento mais polêmico, a autoria negra (EVARISTO, 2011, p. 114).

Sobre essa premissa, Ianni (2011) faz uma ratificação. Para ele, literatura negra é aquela em que o negro é o tema "sob muitos enfoques, ele é o universo humano, social, cultural e artístico de que se nutre essa literatura" (IANNI, 2011, p. 184). Fica explícito nessa afirmação que "A literatura negra é aquela desenvolvida por um autor negro... que escreva sobre sua raça dentro do significado do que é ser negro, da cor negra, de forma assumida, discutindo os problemas que a concernem: religião, sociedade, racismo. Ele tem de se assumir como negro" (IANNI, 2011, p. 185).

Essa compreensão aproxima-se das ideias postuladas por Lobo (2007), logo que a pesquisadora entende que a literatura afro-brasileira contemporânea é carregada da "forma confessional", de uma escrita de "perfil existencial" e com caráter reconstrutor da história do negro brasileiro. Isso significa dizer que ela tem uma linguagem, uma especificidade.

Portanto, deve-se "arrancar a literatura afro-brasileira do seu reduto dentro da literatura em geral, que a trata como tema folclórico, exótico, ou como estereótipo, é preciso que ela seja feita, efetivamente, pelos afro-brasileiros" (LOBO, 2007, p. 331). Mais uma vez tem-se a defesa de que "só pode ser considerada literatura afrobrasileira... aquela criada por afrodescendentes que assumem ideologicamente sua identidade" (LOBO, 2007, p. 340).

Para Lobo a inclusão de textos de autores brancos ou sem uma identificação de pertencimento étnico soa como uma desvalorização do caráter afro dessa literatura e minimizaria a proposta do projeto literário que a mesma propõe. De modo que, "retirar da literatura afro o traço da negritude é novamente misturá-la na produção geral em que se confundirá com a imensa quantidade de obras de autores brancos que falam sobre negros, quer vendo-o sob o ângulo dos estereótipos de modo consciente, quer de modo inconsciente" (LOBO, 2007, p. 328). 
Considerando essas declarações, de modo menos reflexivo, apesar de serem negros, escritores como Cruz e Souza e Machado de Assis estariam fora dessa literatura, pois suas escritas não se desviam do modelo europeu, eles fazem concessões temáticas para tentar inserir-se no mundo literário, e não declaram, explicitamente, no texto, seu pertencimento étnico. Assim, os elementos constituintes da literatura afro-brasileira apontados por Evaristo e Ianni, em parte serviriam mais para classificar, como bem disse Lobo (2007), apenas a escrita de alguns escritores, em especial os contemporâneos, já que o momento histórico de autores como Cruz e Sousa e Machado de Assis não era propício para uma escrita que não tivesse um caráter mais velado.

A escrita muitas vezes velada de Machado de Assis foi mais uma estratégia de resistência do que uma recusa a uma identidade negra. Seguiram estratégias diferentes outros autores do século XIX, como Luiz Gama, o qual se posicionou etnicamente com publicações de poemas abolicionistas, mas em consequência desse posicionamento, como esperado, ficou fora da historiografia literária, à margem do cânone.

É importante registar que a opção por uma escrita com identificação étnica indireta não foi apenas uma posição estratégica de inserção ou permanência no campo literário. Há escritores contemporâneos, como Marilene Felinto que apesar de representar os problemas dos negros brasileiros, especialmente da mulher negra (em As mulheres de Tijucopapo, 1980), não quer ver suas obras relacionadas à literatura afrobrasileira ou feminina, apenas almeja o reconhecimento de escritora da literatura brasileira (DUARTE e FONSECA, 2011). Possivelmente teme ser excluída do cânone, em longo prazo, caso sua obra seja filiada a qualquer minoria.

Na contramão à ideia de exclusão desses escritores, Ianni esclarece que uma das operações "ideológicas" da literatura negra é a intenção de resgatar os escritores fundadores dessa literatura de um discurso limitado e simplista; e mostrar como eles falam para além do seu tempo e são importantes para se "repensar aspectos fundamentais da dialética arte e sociedade, literatura e consciência”. Nesse sentido, Ianni acaba sendo flexível ao abarcar nessa produção literária escritores precursores que aparentemente estariam fora, pelo fato de não terem se desviado das formas e influências eurocêntricas.

Essa discordância se justifica pela ideia de que a crítica literária tem a missão "de libertar Cruz e Souza da metáfora da brancura simbolista; Machado de Assis, da compostura do maior escritor da literatura brasileira, com a glória da fundação da Academia Brasileira de Letras; e Lima Barreto, do escritor gramaticalmente vacilante, o cronista do subúrbio" (IANNI, 2011, p. 185-186). 
Em suma, isso seria a tentativa de "redimensioná-los no âmbito da literatura brasileira", o que seria relevante para a constituição da literatura negra enquanto "tema e sistema". Assim o próprio "Machado de Assis pode ser um clássico da literatura negra, assim como o é da brasileira. E talvez pelo mesmo motivo. Além da escritura, do estilo literário, da exploração da linguagem, da descoberta do idioma, pode haver um elemento fundamental para que ele seja clássico, duas vezes." (IANNI, 2011, p. 188).

A posição de Ianni leva à compreensão de que a exclusão de escritores como Machado da literatura negra ocorre porque o método de leitura não foi o adequado. Seria necessário "aderir ao espírito de sua ficção, entrar em sua visão do mundo. Nela é que podem encontrar-se os nexos, significados ou outros elementos, conscientes no escritor, que oferecem o segredo da questão. E o segredo da questão está na sua visão do mundo, fundamentalmente paródica" (IANNI, 2011, p. 188-189). Assim, seria possível localizar as marcas de pertencimento étnico contidas na presença do negro ou mesmo na ausência.

Ainda com a pauta da autoria da literatura afro-brasileira, a posição da ficcionista e também crítica literária Conceição Evaristo, em entrevista a Duarte, é alicerçada pela perspectiva da experiência, do fazer literário, o que mais uma vez pode significar um fator de distanciamento da escrita de alguns escritores em relação a seu enquadramento na literatura afro-brasileira, ou mesmo aponta a existência de não apenas uma dinâmica e estilo, mas uma variação de escrita:

\footnotetext{
Eu sou uma escritora brasileira, mas não somente. A minha condição de brasileira agrega outras identidades que me diferenciam: a da mulher, a de negra, a de oriunda de classes populares e outras ainda, condições que marcam que orientam a minha escrita, consciente e inconscientemente. Nesse sentido, não tenho receio algum em não só afirmar a existência de uma literatura afro-brasileira, como ainda me encaixar no grupo de autoras/es que criam um texto afro-brasileiro. E ainda asseguro a existência de um texto feminino negro, ou afro-brasileiro, como queiram. O meu texto se apresenta sob a perspectiva, sob o ponto de vista de uma mulher negra inserida na sociedade brasileira (EVARISTO, 2011, p. 114).
}

Além de apostar na ideia de "escrevivência" como fator que justifica a autoria negra da literatura afro-brasileira, com o acréscimo da condição de gênero, Evaristo aponta, ainda, para uma diversidade bem maior dessa literatura, uma literatura afrobrasileira feminina. De modo que Ponciá Vicêncio e Becos da Memória não seriam apenas obras da literatura afro-brasileira e sim da literatura afro-brasileira feminina, o que torna ainda mais complexa a nominação dessa literatura suplementar e aponta a necessidade de critérios pluralistas para a configuração da literatura brasileira. 
Se a literatura afro-brasileira é constituída do ponto de vista da perspectiva do texto é possível pensar que esse ponto de vista é dado por um autor; embora ele crie narradores para assumir esse ponto de vista é dele que parte a criação, assim, o que Evaristo salienta é que o ponto de vista de um escritor branco, ainda que fosse bem maquinado, no sentido de construção, ainda não constituiria uma perspectiva ideal, estaria mais distante de uma possibilidade de verossimilhança. Mas também, afirma que "não basta ao escritor/a ser negro/a para fazer-se uma literatura negra".

Portanto, as escolhas autorais para efetuar a criação literária como a construção das personagens, do enredo e o uso da linguagem estão vinculadas ao local de voz desse artista, às suas experiências enquanto sujeito:

\begin{abstract}
O sujeito autoral da escrita - aquele que cria o texto - é isento de qualquer participação nesse mesmo texto? O texto nasce de quem? Explicitando melhor: para mim, a autonomia da literatura afro-brasileira em relação ao sujeito autor/a é relativa, e muito. O ponto de vista que atravessa o texto e que o texto sustenta é gerado por alguém. Alguém que é sujeito autoral, criador/a da obra, o sujeito da criação do texto. E, nesse sentido, afirmo que, quando escrevo, sou eu, Conceição Evaristo, eu-sujeito a criar um texto e que não me desvencilho de minha condição de cidadã brasileira, negra, mulher, viúva, professora, oriunda das classes populares, mãe de uma especial, Ainá etc., condições essas que influenciam na criação de personagens, enredos ou opções de linguagem a partir de uma história, de uma experiência pessoal intransferivel (EVARISTO, 2011, p. 115).
\end{abstract}

Fica entendido que para Evaristo a condição étnica e de gênero, entre outras marcas identitárias, comporta uma experiência distinta da do homem branco, pois a experiência pessoal é fator de influência na criação estética, ou seja, conduz o ponto de vista do texto. Logo, a escrita do negro é diferente da escrita do branco, pois suas experiências, partilhadas com o grupo, refletem-se na arte literária: “A exploração que os negros vivem é uma realidade que o artista branco repudia, ele recusa ser o agente, pois essa realidade se situa fora dele, ele a vê por meio de um filtro, de um julgamento moral ou por uma empatia racial" (EVARISTO, 2011, p. 116).

É com esse "elemento vital na constituição de uma literatura afro-brasileira - a autoria", que Conceição Evaristo acaba se distanciando do pensamento da crítica Zilá Bernd (1988) em relação aos marcadores estilísticos da literatura negra:

Nesse sentido é preciso sublinhar que o conceito de literatura negra não se atrela nem à cor da pele do autor nem apenas à temática por ele utilizada, mas emerge da própria evidência textual cuja consistência é dada pelo surgimento de um eu enunciador que se quer negro. Assumir a condição negra e anunciar o discurso em primeira pessoa parece ser o aporte maior trazido por essa literatura, constituindo-se em um de seus marcadores estilísticos mais expressivos (BERND, 1988, p. 22). 
Bernd traz outro ponto de vista acerca das propostas de uma crítica questionadora do nosso cânone literário. Ela acrescenta novos elementos que servem à discussão do conceito de literatura afro-brasileira como, por exemplo, a ideia de um "eu enunciador que se queira negro" (no caso da poesia). "Esse eu lírico em busca de uma identidade negra instaura um novo discurso - uma semântica do protesto - ao inverter um esquema onde ele era o Outro... passando de outro a eu, o negro assume na poesia sua fala e conta a história de seu ponto de vista" (BERND, 1988, p. 50).

A autora adiciona, também, a proposta de construção textual de uma "nova ordem simbólica”, opostas às percepções estereotipadas, tanto negativas como positivas. Assim a literatura "torna-se um espaço da destruição de uma simbologia estereotipada" (BERND, 1988, p. 89), espaço em que se busca reverter os referentes negativos ao negro a fim de transformá-los em positivos.

Bernd também traz o conceito de "reversão de valores", que parece estar ligado à ideia da nova ordem simbólica, uma vez que também se trata de uma ideia de “desconstrução, de demolição de verdades, que negam o negro, buscando substituí-las por outras que, ao contrário, afirmam e exaltam sua condição humana" (BERND, 1988, p. 86). E, por fim, há a abordagem da "construção de uma epopeia negra”, o que na verdade seria a revisão da história do povo negro e a tentativa de preencher as lacunas deixadas pela história tradicional.

Em relação "a nova ordem simbólica", a "reversão de valores" e a "construção da epopeia negra", ou melhor, revisão histórica, os conceitos parecem ser ratificados entre os estudiosos da literatura afro-brasileira, porém a ideia de um "eu enunciador que se quer negro" é questionada por alguns, como foi apresentado até aqui pelas ideias de Duarte (2011) e Evaristo (2011).

Ainda sobre esse marcador estilístico da literatura negra, pontuado por Zilá Bernd, em que se expõe um sujeito de enunciação - um eu negro - que se apresenta e quer ser visto como negro, Cuti, em entrevista a Duarte (2011), afirma que a ideia não basta, mas é um ponto de partida importante, pois atende um elemento fundamental, $a$ produção. Mas é insuficiente por não incluir um narratário, que seria "um leitor ideal" em que suas experiências de leitura fossem redimensionadas. Ele chama atenção para a necessidade de se fazer pesquisas de como está sendo recepcionada a literatura afrobrasileira, pois ela está formando leitores onde não havia nenhum (CUTI, 2011, p. 48).

Para Cuti, o escritor branco possui limitação empática para representar o negro, mas por outro lado, o negro se "autocensura" no processo de criação (CUTI, 2011, p. 53). Essa autocensura do escritor negro para Cuti ocorre quando o branco é o leitor ideal 
da obra, fato denunciado, de acordo com ele, por Luís Gama: "Desculpa, meu amigo/ eu nada posso te dar na terra que rege o branco/ nos privam até de pensar" (CUTI, 2011, p. 53). Cuti vê nesses versos a consciência de Gama sobre o "travamento do pensamento pelo ato de seu destinatário ser um branco, de seu leitor ser um branco". A literatura para negros permite que o escritor "pense que vai ser lido por um negro, e isso no íntimo da criação é uma liberação fantástica”, o escritor sente a receptividade do leitor por meio de eventos, sente que suas dores são compreendidas pelo leitor:

\begin{abstract}
Dessa maneira, a literatura negro-brasileira surge para leitores como uma singular oportunidade de reflexão relativa às suas convicções e fantasias pessoais. A subjetividade negra é intransferível, mas ela é comunicante pela semelhança de seu conteúdo humano. Por essa via da semelhança e por um movimento empático e cognitivo do outro, podemos arrenda-los de forma convincente, parecendo verdade nossa interpretação. Afinal, os atores realizam isso com treino e técnicas. O escritor, para mergulhar no universo do diferente, necessita atuar como um ator na escrita, como se o outro fosse. No Brasil, os escritores brancos poderiam ter oferecido ao seu público tais experiências, mas perderam e perdem essa oportunidade por se negar estar não na pele, mas no coração de um negro e, a partir daí realizar seu texto. É que os preconceitos também têm sua profundidade e participam da moldagem da personalidade e até do estilo (CUTI, 2010, p. 87-88).
\end{abstract}

Cuti julga esses elementos importantes para que a literatura negra não tenha mais travamentos, logo no nascedouro, e quando esses elementos não são possíveis, a literatura constitui-se em "um exercício de fazer malabarismos metafóricos para se esconder". De modo que o que se objetiva nesse fazer literário "é justamente o destravamento, e, no momento que a gente conseguir isso com bastante desenvoltura, creio que nós vamos destravar os demais escritores brasileiros com relação a essa empatia profunda com o universo subjetivo do negro" (CUTI, 2011, p. 54).

Bernd compreende que a Literatura negra deve ser evidenciada no texto através de uma "consciência de um existir negro" (BERND, 1988, p. 22) e não por meio da cor da pele do escritor. Os valores dessa literatura na concepção de Zilá Bernd perpassam pela ruptura de modelos de escritura impostos pelo branco e pela apropriação de novas formas de expressão que não saiam de um contexto literário brasileiro.

Trata-se de uma desconstrução de um mundo construído unicamente pelo branco para a ressignificação ou releitura de seu próprio universo cultural. Assim, a legitimação da literatura negra deve ser assinalada exclusivamente pelo "modo negro de ver e de sentir o mundo, e a utilização de uma linguagem marcada, tanto no nível do vocabulário quanto nos dos símbolos, pelo empenho de resgatar uma memória negra esquecida" (BERND, 1988, p. 22). Nesse sentido a posição de Bernd (1988) aproximase das ideias postuladas tanto por Duarte (2011) quanto por Evaristo (2011). 
Também em entrevista a Duarte (BERND, 2011, p. 149-150), Bernd menciona o binarismo de David Brookshaw em seu trabalho Raça e cor na literatura brasileira (1983), como algo sintomático. "Separar autores em brancos e negros é racismo, implica divisão, classificação arbitrária, por isso o caminho escolhido em Angola foi da valorização a identidade nacional, e não cultural" (BERND, 2011, p. 149). Considera a classificação rígida e em busca de desmontar esse binarismo propõe que seja o "eu enunciador- que- se- quer-negro que vai caracterizar um poema como negro". Portanto, literatura negra para Zilá Bernd não é exatamente aquela realizada por negros, mas é a evidência textual que vai defini-la, independentemente da etnia do escritor.

Além de apresentar essas controvérsias com outros críticos literários em relação à autoria da literatura negra, Zilá Bernd comete um equívoco ao reduzir a literatura negra a apenas uma denúncia de um sistema de exclusão dos negros brasileiros e da sua cultura e por apontar a exclusão cultural que sofreram os brancos de outros países de modo semelhante ao caso dos negros brasileiros.

A crítica equipara as dificuldades e opressões vivenciadas pelos negros brasileiros aos dos brancos de outras nacionalidades, como se o fato de ser negro não fizesse diferença ou não aumentasse ainda mais o grau de exclusão. E mais uma vez confirma a ideia de que o interessante é o artista ter sensibilidade para apreender a dor do outro. Dentre outros sentidos, entende-se que não é necessário ter a pele negra. Bernd exclui assim as ideias de Conceição Evaristo de "escrevivência":

\footnotetext{
Na verdade, a grande marca identitária da literatura negra brasileira é a denúncia de um sistema infindável de exclusões pelas quais passam o negro e sua cultura, vitimados pelo estigma de ter vivido a diáspora e a traumática experiência da escravidão. A abolição não resolveu este problema, criando outros. Ora, brancos também foram excluídos em determinadas culturas em diferentes situações históricas, tendo sido as culturas de que eram portadoras minimizadas e secundarizadas no interior do sistema de que participavam. Logo, para expressar dor, sofrimento, exclusão, o importante é a capacidade do autor de ouvir esse rumor discursivo e de captar com sua sensibilidade as queixas de sua comunidade. Independentemente da cor da pele, o verdadeiro artista é o que capta e expressa o que de essencial aflige a humanidade: sofrimento, amor, morte, perdas, ganhos. Ter que recorrer à foto do autor ou a sua carteira de identidade para saber se ele é ou não negro não deveria ser a preocupação principal do crítico. (BERND, 2011, p. 153)
}

Ainda em entrevista a Eduardo de Assis Duarte, Bernd diz que a exigência da presença do eu enunciador que se declare negro como condição para existência da literatura negra só funciona na poesia, pois na prosa há a instância do narrador, de modo que essa ideia restringiria a visão do crítico: "Esse critério do eu enunciador é válido unicamente para a poesia e, mesmo assim muitas vezes a afirmação identitária negra pode se manifestar de modo muito sutil" (BERND, 2011, p.151). 
Enquanto Conceição Evaristo defende a ideia de uma consciência negra explícita e muito bem marcada no texto, Zilá Bernd entende que a vinculação à identidade negra pode ser mais sutil, e muitas vezes pode estar no não dito, isso porque a teórica acredita que cabe ao leitor a empreitada de produzir as possíveis interpretações, e a linguagem elaborada e velada seria mais contundente e alcançaria mais espaço na literatura do que os textos de caráter explicitamente engajados ou panfletários. Por exemplo, "no que diz respeito à prosa poética do Edmilson, é muito difícil encontrar uma frase representativa da resistência negra, pois a força do poema está no conjunto, na enunciação como um todo, naquilo que se lê em filigrana, nas alusões e na força da linguagem metafórica" (BERND, 2011, p. 151). O exemplo a seguir mostra o modo sutil e ao mesmo tempo forte da poesia de Pereira (2002) que, a partir de uma voz afrodescendente implícita no discurso, mas com temática afro-brasileira e um ponto de vista identificado, sem muitas referências aos símbolos afro, denuncia a exploração do corpo negro para construir a riqueza do branco:

\author{
OURO PRETO \\ roteiro de interpretação \\ Ao contemplar o barroco das igrejas \\ e a rouquidão do ouro, o visitante olhar \\ não funde o corpo ao tempo: outeiros \\ tão escuros e não compreende o silêncio \\ de um totem antes jamais percebido. \\ O barroco não é o cansaço do ouro \\ mas o direito do explorado corpo.
}

(PEREIRA, 2002, p.39)

Além de discordar de Evaristo em relação à autoria da literatura afro-brasileira, Bernd distancia-se também da ideia de que possa existir uma literatura afro-brasileira feminina, uma vez que interessa a sensibilidade do escritor para representar a mulher: "a sensibilidade não tem cor. Isso vale igualmente para o gênero: se há determinadas marcas identitárias que fazem com que a gente possa falar de escritura feminina, penso que um homem pode descrever a alma feminina com igual nível de sensibilidade. Um poder inquestionável para esse caso é Marcel Proust” (BERND, 2011, p.153). Mais uma vez o discurso de Bernd contrapõe-se à ideia de "escrevivência" de Evaristo.

Ainda sobre o que seria a literatura afro-brasileira, é perceptível que as ideias de Duarte (2011) e Evaristo (2011) têm maiores ressonância no campo crítico. Por exemplo, têm-se como concordância dessas ideias as abordagens de Cuti (2011), o qual 
profere que o mais importante nessa busca de definição de uma literatura negra "é localizar uma desconstrução a partir do lugar de onde parte o discurso".

Mais uma vez, perpassa-se na ideia do leitor, o ponto novo que Cuti acrescenta a essa discussão. Para ele a desconstrução, antes mencionada, não se refere apenas à escolha de produzir contradiscursos no texto, mas também diz respeito à relação desses com o mundo recepcional: "Refiro-me ao leitor negro, feito personagem, com a concepção de um interlocutor negro que habitará o texto, e, ainda, como a possibilidade de um 'leitor ideal negro' (CUTI, 2011, p. 46)”.

Nesse viés a literatura afro-brasileira é possível mediante a existência de um público leitor, de um narratário negro. Portanto, o desafio dessa literatura é o de conquistar leitores negros. "Criando condições para transformar, pela rebeldia, o 'repertório' do leitor brasileiro, que terá de despertar para a existência de uma linguagem negra" (LOBO, 2007, p. 269). Para isso, a estratégia é fomentar esse contradiscurso em que o negro torna-se o centro da narrativa e que a representação cause uma identificação com esse leitor ideal negro.

Sobre a questão autoral, Cuti concorda especialmente com as ideias de "escrevivência" de Evaristo, quando postula que para escrever literatura negra é preciso despojar-se da brancura e é isso que "os escritores negros vêm fazendo". O escritor branco até pode tematizar o negro na literatura, mas ainda "não teve distensão psicológica para chegar a essa empatia na criação. O leitor negro não passa em seu horizonte criativo. A subjetividade intransferível ainda continua sem o exercício empático por parte de autores brancos" (CUTI, 2011, p. 46).

Cuti posiciona-se na defesa da existência de uma estética literária negra em oposição a uma estética literária branca ou ocidental. A literatura negra seria a possibilidade de reinventar o negro para que esse não continue acreditando ser aquilo que o branco determina ou acredita ser o negro, e nesse momento a literatura negra acaba também por reinventar o branco, "minando seus pés de barros, sua prepotência de simbolizar toda a humanidade". Ao elucidar que "criar é ir além da preocupação com o outro" e que "criar quilombos quase nunca exigia a destruição da casa-grande", Cuti pressupõe que essa literatura não propõe uma derrubada da literatura "canônica/casa grande", mas exige o lugar de uma literatura suplementar, pressupõe uma resistência, e essa resistência é realizada pelo ato da produção literária. (CUTI, 2011, p. 57).

Octávio Ianni (2011), em Literatura e consciência, faz um breve relato da história da literatura negra, conta que a mesma passou por uma linha de evolução para chegar a uma autonomia, surge aos poucos até ganhar mais visibilidade e espaço. 
Aparece dentro e fora da literatura brasileira. Provavelmente esse dentro se refere a obras de autores canônicos, como Cruz e Souza, e fora refere aos marginais que consolidaram de modo declarado uma literatura suplementar:

\begin{abstract}
A literatura negra é um imaginário que se forma, articula e transforma o curso do tempo. Não surge de um momento para outro, nem é autônoma desde o primeiro instante. Sua história está assinalada por atores, obras, temas, invenções literárias. É um imaginário que se articula aqui e ali, conforme o diálogo de autores, obras, temas e invenções literárias. É um movimento, um devir, no sentido de que se forma e transforma. Aos poucos, por dentro e por fora da literatura, surge a literatura negra, como um todo com perfil próprio, um sistema significativo. Um sistema no sentido de "obras ligadas por denominadores comuns", com "notas dominantes" peculiares desta ou daquela fase, deste ou daquele gênero (IANNI, 2011, p. 183).
\end{abstract}

Para Ianni (2011) a literatura negra é caracterizada por um conjunto de denominadores que vão além de elementos internos como a língua, temas e imagens. É organizada, também, por "elementos de natureza social e psíquica". Entre eles têm destaque: os produtores literários, que possuem em alguma medida uma consciência do seu papel; os receptores, que validam a existência da obra; e o mecanismo transmissor, entendido aqui como linguagem ou estilo literário, que liga os elementos uns aos outros. Ianni compreende a literatura negra como um "sistema aberto, em movimento, diferenciado; às vezes também contraditório, que se desenvolve e recria”. (IANNI, 2011, p. 184).

Cabe considerar que quando se trata dos elementos "receptores" ou “destinatários", apontados por Ianni (2011) e Cuti (2010), o leitor branco não é excluído, apesar de o leitor negro representar uma importância na legitimação da literatura negra. $\mathrm{O}$ branco é colocado em cena pela possibilidade do mesmo realizar uma nova leitura do mundo, de si mesmo e do Outro, a partir do estranhamento:

\begin{abstract}
Nós estamos possibilitando ao leitor branco a possibilidade do estranhamento, fundamental para a literatura. Quando um leitor branco pega um texto e não se vê como referência, não se vê como referência do destino do texto, ele passa a ter uma experiência muito mais profunda do que essa coisa habitual de que eu sou o centro de tudo. Então ele passa a enxergar o mundo por outra ótica. Ou seja: "o Outro existe, o Outro me vê com seus próprios olhos". Acho isso importante. E quando eu falo de branco, eu não estou falando do branco epidérmico, estou falando até de um negro que se sente branco, que está arraigado a essa brancura, que no fundo é um desejo neurótico de não ser negro, e que vem do branco (CUTI, 2011, p. 67).
\end{abstract}

Assim, tanto Ianni (2011), quanto Cuti (2011), afirmam a importância de um receptor negro da literatura negra, mas também não descartam a necessidade de leitores brancos. Isso não só como estratégia para uma consolidação no campo literário, mas, 
sobretudo, como a saída para a conscientização de brancos e negros em relação à capacidade do negro de expressar o mundo por meio de um discurso próprio.

Até aqui foram apresentadas as visões de autores que pensam em uma autoria negra para a literatura afro-brasileira, outros que pensam em um autor branco ou negro, desde que se queira negro e aquela que se elegeu como a mais sensata, a perspectiva de uma autoria que passa pela ideia de um sujeito afrodescendente não apenas no sentido da cor, mas também de uma identidade negra, que pode ser ou não declarada no texto.

\subsection{Valor sociológico $X$ valor estético}

Sobre os aspectos de escolha da criação narrativa, a literatura afro-brasileira, por vezes tem sido acusada de apenas apreciar o elemento sociológico em detrimento ao estético, ou seja, valorizar o ideológico e não se preocupar com a forma. O que é um erro, pois, como bem afirma Cuti, "nenhuma legitimação é apenas estética. No mais das vezes é ideológica” (CUTI, 1987, p. 156).

Cuti traz com essa afirmativa a ideia de que o estético e o ideológico não estariam dissociados, essa tendência de compartimentação soa como uma tentativa de anular a importância e o valor das literaturas que assumem um engajamento político. Nesse sentido é inviável questionar a qualidade estética da literatura afro-brasileira, até porque o elemento sociológico funciona também como um elemento estético na composição poética dessa literatura suplementar.

Luiza Lobo, em Crítica sem Juízo (2007), também se pronuncia sobre o lugar do estético, afirmando que na poesia negra deve-se levar especialmente em conta, "mais oportunidades do que a qualidade”. Deve ser privilegiado o valor político e cultural do texto e não tanto assim os valores estéticos ou a forma, já que a posição política pode ser considerada uma posição estética. Em suma, é a emergência de uma literatura suplementar que modifica a lógica da "dialética do corpo da linguagem”, anterior:

Focalizando a literatura afro que surgiu desde a década de 1970 como uma possibilidade de releitura cultural, percebe-se que, nesta fase, não importa sua qualidade, mas sim sua oportunidade. Noutros termos, até o momento, é o movimento ideológico que ele carrega para as consciências que torna um documento importante, para além dos estereótipos e independe de sua qualidade. É o próprio sintoma de sua emergência que altera a dialética do corpo da linguagem, que passa a expressar uma nova mensagem, pois inverte a ordem do colonizador e introduz novos parâmetros na discussão da cultura nacional (LOBO, 2007, p. 268, grifos da autora). 
Ao afirmar que a literatura afro-brasileira precisa, ou já precisou de mais oportunidade do que de qualidade, Lobo (2007) não reduz a literatura afro-brasileira a uma produção meramente ideológica, como se ela tivesse apenas caráter político e não literário, o que a levaria a ser classificada como uma produção fora dos critérios estéticos da representação e enunciação textual. O que ocorre é a celebração da ideia de se criar "condições para seu desenvolvimento. Está no mesmo caso a literatura de autoria feminina. $\mathrm{O}$ critério estético, portanto, tem de ser posterior à própria afirmação da literatura afro, sob pena de, em caso contrário, agir como filtro repressor a sua produção" (LOBO, 2007, p. 340).

E por falar em critérios estéticos, vale pensar sobre a noção de valor e como ocorre a construção social do valor estético. Terry Eagleton em Teoria da literatura: uma introdução (1994) trata o valor com a ideia de transitividade, considerando a concepção de arte como algo passível de mutabilidade, embora a visão de arte muitas vezes seja hegemônica, ocidental e etnocêntrica. Eagleton entende que os julgamentos de valor estão relacionados com o que se considera literatura, e o que não se considera, e isso "não necessariamente no sentido de que estilo tem de ser "belo" para ser literário, mas sim de que tem de ser do tipo considerado belo" (EAGLETON, 1994, p. 11), ou seja, a definição de literatura está imbricada numa acepção vazia e autoritária. Para ele a classificação de um texto como literatura é extremamente instável (EAGLETON, 1994, p.13), os juízos de valor que constituem a literatura "são historicamente variáveis... têm, eles próprios, uma estreita relação com as ideologias sociais. Eles se referem, em última análise, não apenas ao gosto particular, mas aos pressupostos pelos quais certos grupos sociais exercem e mantêm o poder sobre outros" (EAGLETON, 1994 p. 17). Portanto, as escolhas dos critérios estéticos para nomear uma obra literária boa ou ruim, ou não literária são ideológicas e atendem às necessidades de poder das classes dominantes, as quais, mais do que conter alguns valores sociais, difundem outros por meio da literatura, e esses interesses podem ser atualizados. Como bem registrou Eagleton, em outra conjuntura histórica:

Os critérios do que se considerava literatura eram, em outras palavras, francamente ideológicos: os escritos que encerravam os valores e "gosto" de determinada classe social eram considerados literaturas, ao passo que uma balada cantada nas ruas, um romance popular, e talvez até mesmo o drama, não o eram. Nessa conjuntura histórica, portanto, o "conteúdo de valor" do conceito de literatura era razoavelmente auto-evidente (EAGLETON, 1994, p. 19).

Em vias de uma ruptura com estruturas de uma linguagem literária anterior e de uma introdução da discussão dos critérios da especificidade literária, a marca da 
literatura afro-brasileira, como bem disse Pereira (1995, p. 2), “a marca de nossa identidade literária pode estar no reconhecimento dessa fratura, que nos coloca no intervalo entre a aproximação e o distanciamento das heranças da colonização". Nesse sentido, a literatura afro-brasileira está empenhada em justamente fazer essa transitividade, esse deslocamento de valor literário autoritário ou no afastamento da escrita como uma preocupação individual, diferentemente das concepções de Bloom (1995), o qual pensa o estético como uma preocupação individual e não social e aponta para o individual como o único método para a apreensão do valor estético, isto é, a concordância com a autoridade estética do gênio.

Jaime Ginzburg, em Cânone e valor estético em uma teoria autoritária da literatura (2004) vê nas concepções de Bloom (1995) a fundamentação de uma lógica narcísica que "opera em direção à delimitação precisa da incongruência entre ego e alteridade" (GINZBURG, 2004, p. 106) e entende também o trabalho de Bloom como autoritário pela insistência de conservar valores que só consolidam barreiras sociais e contrariam os interesses dos valores democráticos, uma vez que defende a autonomia do cânone e despreza os estudos críticos-teóricos associados à raça, etnia e gêneros.

Posições autoritárias e equivocadas como as de Bloom (1995) nos permitem compreender os motivos que levaram obras como o romance Úrsula, de Maria Firmina dos Reis, publicado em 1859, o qual apesar de ter sido o primeiro romance de uma mulher brasileira publicado no Brasil, o primeiro romance brasileiro abolicionista, o primeiro romance afro-brasileiro e de sua obra superar o ponto de vista comum sobre a representação do negro nos romances abolicionistas dos seus contemporâneos a exemplo de A escrava Isaura (1875) de Bernardo Guimarães (MARTIN, 1988, p. 9), ainda assim, com todas essas credenciais de ruptura, esses não foram motivos suficientes para Úrsula fazer parte da historiografia literária brasileira. Este fato só reforça a ideia de que parte da história cultural dos afrodescendentes tem sido silenciada pelas críticas e teorias autoritárias, bem como a exclusão historiográfica/estética do escritor negro parece estar conectada a sua própria exclusão social.

Ainda enfatizando que a legitimação de um texto enquanto literário passa pelo interesse de alguém, Eagleton (1994), à luz da argumentação de John M. Ellis, exemplifica isso ao afirmar que a palavra literatura funciona como a palavra "mato", enquanto mato está dentro de um conjunto variado de plantas que, conforme a subjetividade de um jardineiro, não cabe no contexto do jardim, literatura opostamente seria uma gama variada de textos que por alguma razão seja tão valorizada, razões que Eagleton não tinha esclarecido no momento, mas logo explica que estão atreladas a 
quem definiu que esse texto é possuidor de valores em relação a outros e de quem define esses critérios.

Quem garante que o mato arrebatado não seja também valioso, embora possua valores diferentes das plantas que ficaram? Seguindo a lógica de interesse do grupo que seleciona, certamente fica o texto que representa os interesses hegemônicos. Essa exemplificação aponta para o papel social do texto bem como as finalidades que podem ser dadas e as práticas humanas em que se deposita. Assim, Eagleton entende que não há precisão na escolha ou na definição do que seria a literatura, ou literatura boa ou mesmo literatura ruim, pois "Literatura é, nesse sentido, uma definição puramente formal, vazia. Mesmo se pretendermos que ele seja um tratamento não pragmático da literatura, ainda assim não teremos chegado a uma 'essência' da literatura, porque isso também acontece com outras práticas linguísticas, como as piadas”. (EAGLETON, 1994, p. 10)

A propósito do que venha a ser literatura com valor estético e sem valor estético, serve bem a reflexão de Antoine Compagnon: "Mas a obra de arte como lembra Gadamer, 'não são cavalos de corrida: sua finalidade principal não é apontar um vencedor'. O valor literário não pode ser fundamentado teoricamente: é um limite da teoria, não da literatura" (COMPAGNON, 1999, p. 255). Portanto, a falta de precisão para definir a literatura é um problema que cabe à crítica e à teoria, as quais são formas de leitura da literatura.

Eagleton $(1994$, p. 1) ameniza a responsabilidade da teoria ao afirmar que essa já passou por um desenvolvimento, pois desde a publicação do artigo A arte como artifício, de Victor Sklovski, houve transformações no conceito "literatura", "leitura" e "crítica", mas atribui a dificuldade ao fato de que essas alterações ou revolução teórica no modo de ler a obra literária ainda não alcançaram um bom número de especialistas, pesquisadores e leitores.

Então, é possível apontar a base dessa tensão para o modo como ocorre a leitura da literatura afro-brasileira. Deve ser assinalado o que, na realidade, esses leitores e críticos estão considerando como qualidade estética e questionar o fato de que essa qualidade estética esteja isenta de uma ideologia. O resultado dessa observação é a consideração de que esses leitores entendem que o elemento sociológico dessa literatura é condição para impedi-la de apropriar-se do estético. "Como se ela tivesse a função única de refletir o problema racial brasileiro. Entretanto, há muita beleza em vários textos, capazes de levar o leitor a uma experiência profunda de prazer, pelo que trazem de arranjo, harmonia e inusitada linguagem" (CUTI, 2011, p. 59). Em defesa da 
consideração do político enquanto escolha estética de valor, Eagleton (1994) se pronuncia:

As teorias literárias não devem ser censuradas por serem políticas, mas sim por serem, em seu conjunto, disfarçada ou inconscientemente políticas; devem ser criticadas pela cegueira com que oferecem como verdades supostamente "técnicas", "auto-evidentes", "científicas" ou "universais", doutrinas que um pouco de reflexão nos mostrará estarem relacionadas com, e reforçarem, os interesses específicos de pessoas, em momentos específicos" (EAGLETON, 1994, p. 210).

Em "tempos de desconstrução" e negociação de uma literatura suplementar, é preciso rediscutir o lugar do valor estético. Esse valor estético necessita estar associado a outros valores. O leitor deve estar apto e atento para atuar com essa associação, o ideológico versus o estético e outras noções. "Se não fizer isso, ele cai no idealismo, quer dizer, em um estético estrito, e daí vai buscar certeza no mundo das ideias, de Platão, e estará ainda imaginando que em algum lugar há formas puras ou certas noções que determinariam o que é e o que não é belo" (CUTI, 2011, p. 59).

Assim, o argumento de rebaixamento da literatura afro-brasileira ou qualquer outra literatura por falta de valor estético não se sustenta. Em Conceição Evaristo, além da posição ideológica, os romances apresentam elementos estetizantes relevantes, com destaque para o tratamento dado ao negro, às personagens infantis, ao modo como Evaristo organiza o mundo da criança negra, os próprios efeitos estéticos que a criança negra traz e o lirismo para negociar o conceito de infância - detalhes que serão discutidos no próximo capítulo, em que se pretende fazer uma análise que capta a força da literatura afro-brasileira, de modo que possa transparecer sua potência significativa no espaço literário. 
A negociação da infância nos romances de Conceição Evaristo 
Das crianças vergônteas dos escravos, Desamparadas, sobre o caos, à toa E a cujo pranto, de mil peitos bravos, A harpa das emoções palpita e soa.

As pequeninas, tristes criaturas Ei-las, caminham por desertos vagos, Sob o aguilhão de todas as torturas, Na sede atroz de todos os afagos.

(Cruz e Souza. Cruz e Souza obras completas, 2008, p. 291- 292)

\subsection{A criança negra na literatura afro-brasileira}

“A personagem do romance brasileiro contemporâneo é branca. Os brancos somam quase quatro quintos das personagens, com uma frequência mais de dez vezes maior que a categoria seguinte (negros)" (DALCASTAGNÈ, 2012, p. 173). A partir dessa afirmação e com base no que foi discutido no capítulo anterior, bem como o que foi analisado nos romances de Conceição Evaristo, é possível dizer que o conceito de literatura afro-brasileira, rasura e rompe com essa lógica de representação, por dar espaço e voz a homens negros, mulheres negras e de modo poético, em Conceição Evaristo, à criança negra, seja ela menina ou menino.

Para constatar essa última conclusão, surgiu a seguinte questão: como é representada a infância de crianças negras na literatura afro-brasileira contemporânea? Esse é o ponto que permeia as análises desse capítulo. A necessidade do estudo parte da constatação de que as representações de crianças são raras na literatura brasileira, principalmente se tratando de personagens infantis negras. E essa ausência fica mais acentuada, quando consideramos as crianças negras do sexo feminino. Segundo a pesquisa de mapeamento das personagens da literatura brasileira contemporânea, de Regina Dalcastagnè, em Literatura brasileira contemporânea: um território contestado (2012), dos 258 romances estudados, apenas 6,4\% (30) são crianças entre as personagens do sexo feminino, enquanto os meninos, entre as personagens do sexo masculino aparecem com 7,9\% (61).

A pesquisa mostra a problemática dessas representações ao evidenciar que entre essa pequena porcentagem de aparição de meninos e meninas, poucos deles trazem vestígios da negritude. A investigação demonstra que das personagens brancas aparecem 74 na infância, já as personagens infantis negras somam apenas 09 entre as personagens negras. 
A questão de gênero aparece quando verificamos que dessas nove crianças negras, a menor parte pode tratar-se de meninas, considerando que a mesma pesquisa aponta para um número maior de aparecimento de personagens masculinos em relação às personagens femininas na literatura contemporânea brasileira. Os romances de Evaristo confirmam esses dados quando apresentam em Ponciá Vicêncio dois meninos, o pai de Ponciá e Luandi e apenas a menina, Ponciá. E em Becos da Memória o número de meninos é ainda maior: Negro Alírio, irmão de Nazinha, Beto, Zé, Nico, Toinho, Brandino, Zuim, Tutuca e Jorge da Marta, em contraponto à aparição de apenas seis meninas: Maria-Nova, Nazinha, Menina Catita, Ayaba, Tita e Fuizinha. Interessa dizer que embora esses romances apresentem um número maior de meninos são as meninas que se destacam na narrativa. Em Ponciá Vicêncio é a menina Ponciá a protagonista e em Becos da Memória, apesar de não encontrarmos uma definição bem marcada de um protagonista, percebemos a menina Maria-Nova envolvida em quase toda a trama e boa parte da narrativa é conduzida por sua perspectiva.

No entanto, conforme a pesquisa da Professora $\operatorname{Dr}^{\mathrm{a}}$ Regina Dalcastagnè sobre a personagem do romance brasileiro contemporâneo, a presença dessas personagens infantis é uma exceção. Como já explanado, a figuração de crianças ocupa um lugar claramente periférico na tradição literária brasileira e isso justifica a quase inexistência de crianças negras protagonistas. Na literatura, de um modo geral, as crianças são quase sempre coadjuvantes, sua função se restringe, em grande medida, a compor a personagem adulta.

Não há espaços expressivos na literatura para a representação das crianças, ou licença para que possam falar por si só, e serem ouvidas. Suas falas são consideradas insignificantes e nas ordens discursivas (FOUCAULT, 1996) as crianças sempre estão num patamar inferior. Em geral, aparecem apenas como vestígios, pois não são elas próprias que se representam e nem mesmo narram suas próprias histórias. "A criança não é reconhecida como escritor. Sendo o ofício do escritor apresentar diferentes pontos de vista, é mediada pela voz do adulto que a voz da criança, ou uma ideia de infância, vai poder ser lida na literatura" (MATA, 2010, p. 12).

Nesse contexto, a literatura afro-brasileira surge como uma força em que seus escritores são os atores sociais capazes de dar representatividade à infância. Pois o projeto estético/político dessa literatura, abordado no capítulo anterior, atua para tentar concretizar essa tarefa, tendo, no mais das vezes, caráter visibilizador. Mas é possível questionar até que ponto essa literatura dá conta ou pode representar os discursos sociais 
infantis, bem como o conceito e a imagem da criança negra junto às situações vividas por elas.

De antemão é possível afirmar que as crianças negras narradas na literatura afro-brasileira de Conceição Evaristo são construídas como atores históricos capazes de reagir e engendrar tensões e conflitos para criarem momentos de escape, como forma de resistência às opressões vivenciadas.

É considerando essas informações que esse capítulo pretende examinar a figuração do espaço social (CERTEAU, 1998) da infância nos romances Ponciá Vicêncio e Becos da Memória, de Conceição Evaristo, explicitando o modo como a romancista utiliza a estetização da 'memória' (HALBWACHS, 1990) para colocar a criança negra em cena e apresentar o infantil.

Será considerada a premissa de que as definições de infância emanam de processos sociais e discursivos, compiladas em leis e políticas que se concretizam "em formas particulares de práticas sociais e institucionais, que por sua vez ajudam a produzir as formas de comportamento vistas como tipicamente "infantis" - ao mesmo tempo em que geram formas de resistência a elas". Portanto, a infância aqui discutida parte da premissa de uma construção histórica, cultural, ou seja, passível de variações sociais:

\begin{abstract}
'A criança' não é uma categoria natural ou universal, determinada simplesmente pela biologia. Nem é algo que tenha um sentido fixo, em cujo nome se possa tranquilamente fazer reivindicações. Ao contrário, a infância é variável - histórica cultural e socialmente variável. As crianças são vistas - e veem a si mesmas - de formas muito diversas em diferentes períodos históricos, em diferentes culturas e em diferentes grupos sociais. Mais que isso: mesmo essas definições não são fixas (BUCKINGHAM, 2006, p. 10).
\end{abstract}

Como demonstrada, além de estar fundamentada nessas variações históricas e culturais, essa pesquisa se baseou na ideia de que "o significado de 'infância' está sujeito a um constante processo de luta e negociação, tanto no discurso público (por exemplo, na mídia, na academia ou nas políticas públicas) como nas relações pessoais, entre colegas e familiares" (BUCKINGHAM, 2006, p. 10). Nesse sentido a ideia deste trabalho foi perpassada pela intenção de mostrar o modo como as narrativas de Ponciá Vicêncio e Becos da Memória redesenham as histórias das crianças conferindo-lhes uma identidade (re) significada, isso é, como negociam a representação da infância de crianças negras brasileiras.

O ponto fulcral desta discussão não se afastou da ideia de que as infâncias investigadas nesses romances têm em comum as dificuldades impostas pela herança escravocrata; pois são representações de modelos que passam ao largo de uma 
concepção idealizada, plasmadas por alguns pensadores, como Philippe Ariès (1981). Apesar de ocorrerem em espaços geográficos diferentes, Ponciá Vicêncio em área rural e Becos da memória na cidade, no caso, em uma favela, o espaço social é o mesmo, o da exclusão e discriminação. São infâncias narradas sob o ponto de vista de narradoras preocupadas em provocar a reflexão sobre a gravidade da exclusão da criança negra. Não se trata de narradoras que relatam os acontecimentos como quem assiste a um espetáculo, mas como quem demostra conhecimento da dor do outro; e o local de fala é pertinente para tal.

Para apoiar as discussões sobre memória, tomou-se como base Halbwachs (1990); no que se refere aos conceitos de infância, ancorou-se especialmente em Ariès (1981) e Rousseau (1995), (tendo-se como suporte Ferretti, 2004), em relação às ideias de ocupação do espaço tomou-se como centro do debate as ventilações de Certeau (1998) e para fundamentar a presença da oralidade nas tramas A. Hampaté Bâ (2010) e Mello (2009). Além de outros autores para dar suporte e fundamento às questões levantadas nos capítulos.

\subsection{Memória e esperança: imagens da infância em Ponciá Vicêncio e Becos da}

\section{Memória}

A literatura afro-brasileira, especialmente a produzida na contemporaneidade, pode configurar-se como uma (re) significação das memórias individuais das personagens negras e das memórias coletivas. Trata-se de narrativas em que se revisa o passado histórico através de figurações afirmativas das identidades afro-brasileiras e se desconstroem representações negativas das marcas identitárias.

Em Becos da Memória, esse jogo discursivo se encontra desde o título, o qual faz prenúncio de uma narrativa memorialística e em seguida é assinalado nas imagens da capa, isso nas duas edições da obra. O paratexto da capa também dialoga com o conceito de memória. É sugestivo dizer que ao escolher essas capas a autora ${ }^{10}$ entrega uma chave de leitura que não é necessariamente quesito obrigatório ao leitor, ele pode ou não seguir as pistas iniciais, uma vez que a narrativa já conduz naturalmente para a questão da memória individual e coletiva.

\footnotetext{
${ }^{10}$ A autora declarou em palestra no Seminário de Pesquisa IV- 2013, organizado pelo Grupo de Estudos em Literatura Brasileira Contemporânea (UnB), que as fotos das capas das duas edições de Becos da Memória são pessoais. Indicou a presença de alguns familiares nas fotos, inclusive ela mesma.
} 
Em uma leitura atenta é possível concatenar as imagens das capas à memória dos afrodescendentes. Isso já ocorre com a simples visualização do clichê filtro sépia que desloca os representados do tempo presente para o passado, ou pelo vislumbre das fotos que marcam a questão geracional. A autora também sinaliza para sua concepção de "escrevivência" ao expor fotos pessoais. Algumas mostram sua própria infância, como a primeira foto da $2^{\mathrm{a}}$ edição, em que Conceição Evaristo aparece com vestes de um cerimonial católico e outras expõem familiares de diversas gerações: a criança, o adulto e o velho. A exibição dessas gerações pode ser entendida como o modo de colocar em cena, numa verossimilhança acentuada, personagens de uma história apagada. De modo simbólico, as vozes do ontem são representadas na figura dos idosos; as imagens dos adultos evidenciam as vozes do hoje e as imagens de crianças trazem a ideia de ressonância, o eco da "vida-liberdade", as vozes do futuro. A escolha por essa representação geracional parece anunciar e marca e o conceito de infância relacionada à esperança. Isso conforme a leitura das imagens das capas abaixo:

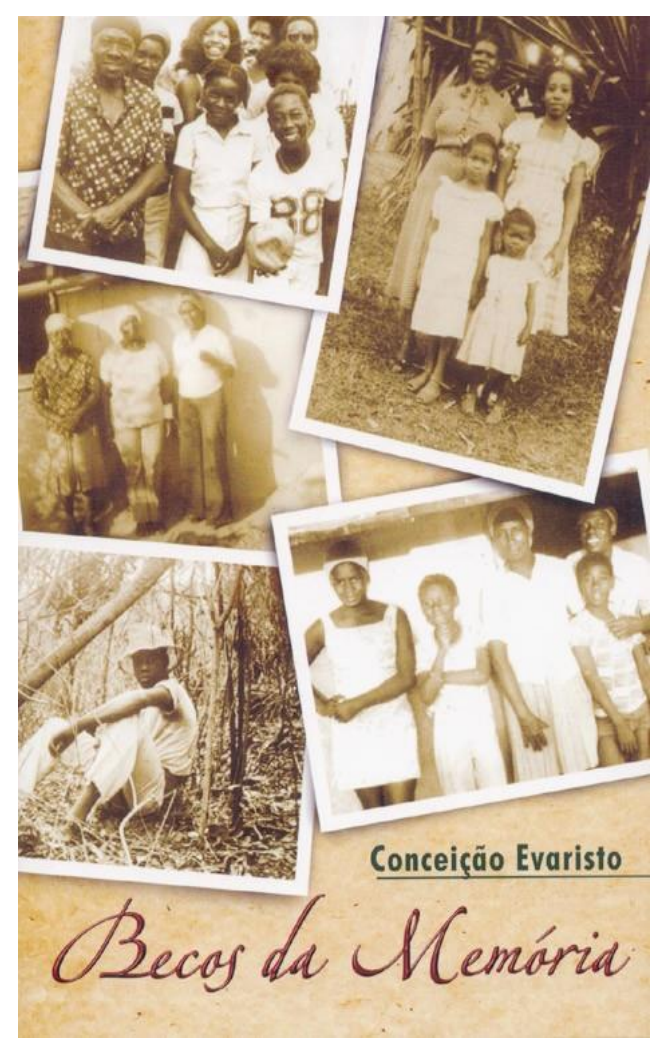

Fonte: http://nossaescrevivencia.blogspot.com.br

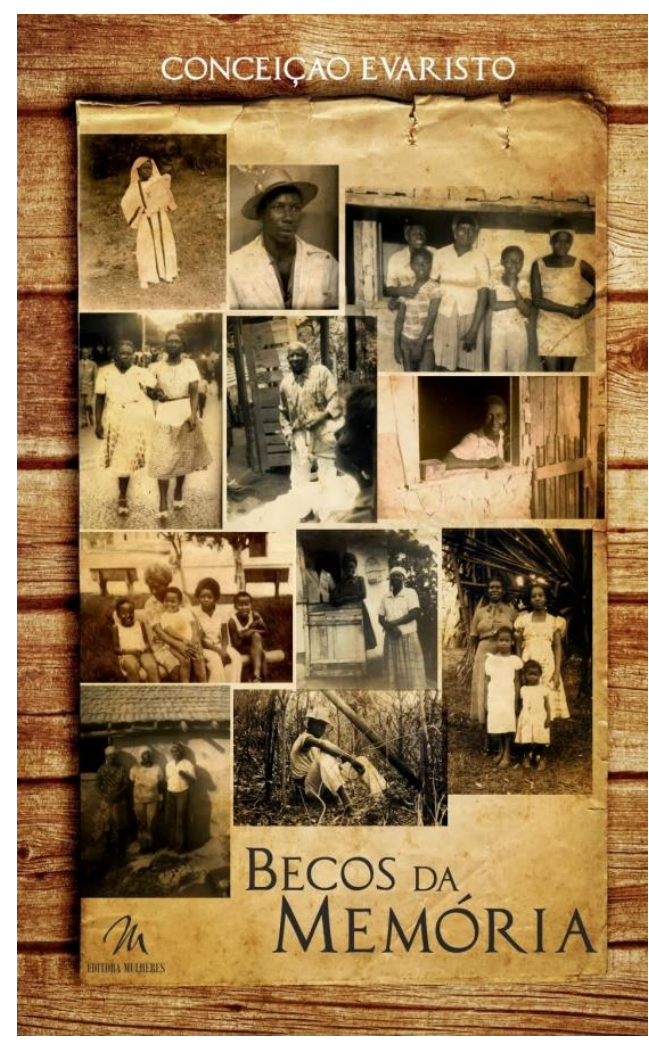

Fonte: http://nossaescrevivencia.blogspot.com.br

A narrativa confirma a impressão das capas, pois a protagonista, Maria- Nova, está exposta às "pedras pontiagudas", presentes nas histórias de dor do Tio Totó, da Maria-Velha e do Bondade. Ela pedia que lhe contassem histórias tristes e as mais 
verdadeiras. "Queria saber o que havia atrás, dentro, fora de cada barraco de cada pessoa" (EVARISTO, 2013, p. 50).

Ouvir os relatos de dor significa para Maria- Nova a incorporação da história dos seus, o reconhecimento desta, como também, sendo a sua própria história, pois a dor dos antepassados agora é sentida por ela. Assim Maria-Nova tem os primeiros contatos com a identidade negra. Essa narrativa do passado representa o espaço em que a memória se manifesta na forma de relato, pois a memória associada à oralidade dirigese ao coletivo simbolizado pelas crianças ouvintes.

$\mathrm{Na}$ narrativa, algumas personagens adultas (Tio Totó e Maria-Velha), ou personagens compreendidas como sábios (Bondade) e até mesmo o jovem sindicalista, Negro Alírio, por apresentarem as características de sábios, contadores de histórias, animadores das crianças, conselheiros ou até mesmo funcionar como mentores espirituais, serão analisados como uma referência aos griôs ou grits" ${ }^{11}$ do tipo "griots genealogistas" como aparece no texto de Hampaté Bâ (2000 p. 193). Com a função de contadores de estórias, historiadores ou poetas (ou os três ao mesmo tempo), essas personagens parecem guardar alguns aspectos das tradições africanas, são representantes dos traços relacionais com a identidade coletiva e, por isso, apresentam tanta identificação com a comunidade. "É a figura sobre a qual recaem a estima e o apreço das novas gerações" (MELLO, 2009).

Cabe dizer que se trata de apenas uma referência ao real, pois os romances como apresentado no primeiro capítulo, configuram uma perspectiva de realismo, que não é representação do real, mas parte de uma perspectiva realista, até porque se a obra corta todas as referências com o real não permite uma entrada para o leitor. É com base nessa posição de representação que busco compreender as personagens dos romances em questão. De modo que não afirmo que elas sejam griotes, mas que é possível compreendê-las por meio dessa referência. É um vínculo com o mundo empírico para fazer a leitura do mundo ficcional.

\footnotetext{
${ }^{11}$ Nas culturas africanas, "existem várias categorias e nomes distintos para os contadores de histórias, de acordo com a cultura que representam. São os dialis, os kpatita, os ologbo, os arokin, que reviveram, nas histórias que contavam a memória da cultura de África. Os jeliya são griots em especial na Gâmbia e no Senegal; são os transmissores da tradição Bambara, Senufo e Mali que dialogam com as tradições Bantu e Dahomery, cuja narrativa é feita em baixo da copa de uma árvore, ao som da kora. Os Koyaté, na Guiné (no Noroeste africano), são os responsáveis por zelar pela memória coletiva e pela conciliação do grupo ao qual pertencem e, assim, preservar, por meio da oralidade, a história do continente e o equilíbrio da sociedade. Os Djeli, Jali, na cultura mandingue, realizam uma série de funções importantíssimas, como a preservação da história e do conhecimento mandingue; sua palavra se faz presente em cerimônias como casamentos, funerais, iniciações, mediações de relações pessoais de diversos tipos, contando histórias, tocando o kora e cantando. Os akpalôs, duelis e alôs são contadores de história na cultura nagô" (MELLO, 2009, p. 149-150).
} 
As explicações de Amadou Hampaté Bâ em Tradição viva (2010) esclarecem o porquê da possibilidade de essas personagens referenciarem os griôs. Ao comentar sobre o que seriam as Tradições Orais, as visões veiculadas por ela, os conhecimentos/ciências que se pretende transmitir e quem seriam os transmissores qualificados, Bâ (2010) aponta para dois grupos tradicionais de transmissores das histórias/culturas africanas: os "tradicionalistas" ("Em Bambara, chamam-nos de Doma ou Soma, os 'conhecedores', ou Donikeba, 'fazedores de conhecimento'; em funali, segundo a região de Silatigui, Gando ou Tchiorinke, palavras que possuem o mesmo sentido de "conhecedor", p.174,175); e os "griôs" (pertence à casta dos Dieli ou dos Woloso, p. 178).

O autor comenta também que não se pode confundir os "tradicionalistas-doma" com os "Griôs-dieli", o primeiro é guardião dos segredos da gênese cósmica e das ciências da vida, dotado de uma memória prodigiosa é o arquivista de fatos passados transmitidos pela tradição e dos fatos contemporâneos. Enquanto se ocupam com as ciências ocultas e esotéricas, os griots envolvem-se com "música, a poesia lírica e os contos que animam as recreações populares, e normalmente também a história, são privilégios dos griots, espécie de trovadores ou menestréis" (BÂ, Hampaté, 2010, p. 193). Sobre a pretensão da fala dos tradicionalistas e griôs Bâ (2010) marca uma diferença significativa. Os tradicionalistas falam em nome do Deus Maa Ngala (criador do universo) simbolizando o Maa, interlocutor de Deus, o primeiro homem e nunca desviam suas falas do fundamento da expressão: “Aquilo que Maa Ngala diz é!" (ibidem, p. 172); Os griots, opostamente após proferir suas narrativas deixam claro que é a visão do homem sobre a veracidade de Maa Ngala, assim se isentam da responsabilidade: "Isso é o que o dieli diz!" (ibidem, p. 196).

O que fica subtendido nessas expressões é que, enquanto os tradicionalistas têm um compromisso com a veracidade, pois pretendem passar o conhecimento herdado da cadeia dos ancestrais sem colocar em dúvida a veracidade da fala, falam na condição de interlocutores do divino. "Mais do que todos os outros homens, os tradicionalistasdoma, grandes ou pequenos, obrigam-se a respeitar a verdade. Para eles, a mentira não é simplesmente um defeito moral, mas uma interdição ritual cuja violação lhes impossibilitaria o preenchimento de sua função" (ibidem, p. 176-177). Em contrapartida, para os griots a disciplina da verdade não é significativa, a tradição permite "travestir ou embelezar os fatos, mesmo que grosseiramente, contanto que consigam divertir o público. O griot, como se diz podem ter duas línguas” (ibidem, p.178). Eles podem usar do cinismo, brincar com o sagrado, não têm compromisso 
algum com a discrição ou com o respeito absoluto para com a "verdade". A tradição aceita as invenções dos dieli, sem se deixar enganar, pois, como se diz, eles têm a "boca rasgada" (ibidem, p. 193).

Esse panorama deixa claro que é possível enxergar em Conceição Evaristo o regate das Tradições Orais na referência aos "griots". A escolha da figura do griot ao invés do tradicionalista pode indicar a posição da autora em relação ao que ela considera representação ideal, aquela que não tem compromisso com a verdade, mas que busca apresentar uma perspectiva da realidade. As personagens que lembram os caracteres dos griots, Tio Totó, Maria-Velha, Negro Alírio e o Bondade apresentam para as crianças as histórias da África, dos negros que vieram de lá para o Brasil, as dificuldades na vida cotidiana passada e atual, mas tudo em um tom de perspectiva. Os fatos são expostos, não como autoritários e únicos, apenas é uma visão do que foi e é a vida do negro escravo e seus descendentes.

Além de considerar que essas personagens assumiram o caráter próximo ao de um griot, também é possível dizer que o engenho da narradora também sinaliza para uma postura de griot, ou seja, o griot é uma categoria/termo que descreve a narradora dessa obra, isso numa licença que não pretende ser realista. Tanto na trama de Becos da Memória como em Ponciá Vicêncio, as narradoras, contadoras de histórias, parecem levar em consideração o outro, fica subtendido que elas esperam serem ouvidas por alguém, contam histórias dos povos negros na esperança de conquistar a atenção de um público específico. O arranjo dos textos em fragmentos ao invés de capítulos e as repetições de palavras e frases, um caso de consciência da interferência da memória, mais uma vez revelam a vinculação das narrativas às tradições orais. O griot é um termo com inscrição histórico-cultural específica que se conecta com os textos em discussão e ainda que o termo seja utilizado de uma forma "generalista", quase mitológica, ele desloca o foco da tradição ocidental para uma tradição "não-ocidental". E, também, inscreve histórica e culturalmente o narrador dos romances de Evaristo.

As atuações do Bondade, Tio Totó, Maria-velha e Negro Alírio, na trama, como guardadores da memória coletiva adquirem expressiva importância para a representação das tradições orais "porque traz consigo a memória profunda que cuida da compreensão do tempo histórico e sua relação com o espaço" (MELLO, 2009). Sinteticamente, são os responsáveis por transmitir às crianças a memória de uma história silenciada, memória que afirma e fortalece a identidade negra:

Com o tempo, a família transmite à criança uma memória - de onde venho, como sou, como serei - que não é exatamente a construída por ela, nem 
poderia ser. $\mathrm{O}$ aspecto importante é que a criança incorpora aquela história como sendo também sua: sua história é a de sua família, sua memória constrói-se de relatos dispersos, numa etnografia real e/ou imaginária que engloba fotos, móveis, objetos pessoais, etc. Por meio da linguagem elaborase uma memória baseada em fatos dispersos, efêmeros, repetitivos, de concretude esfacelada pelo tempo, mas portadora de um simbolismo que leva à afirmação da singularidade do "clã" como lugar de uma identidade que a ele transcende (NUNES, 2003, p. 35-36).

Essa forma de relatar o passado é o regate das tradições orais das culturas africanas, comumente abordada pela literatura afro-brasileira. Nas narrativas em estudo o registro dessas tradições simboliza não só a tentativa de trazer a consciência de uma história, a preservação de uma cultura, mas também funciona como um dispositivo socializador para viabilizar e integrar um povo num tempo e espaço cultural. A arte de contar é a arte de fortalecer, "assim como a fala de Maa Ngala animou as forças cósmicas que dormiam estáticas, em Maa, assim também a fala humana anima coloca em movimento e suscita as forças que estão estáticas nas coisas” (BÂ, Hampaté 2010, p. 193). A função dos contadores dos romances é essa de potencializar as forças estáticas nas crianças:

Função designada ao ancião de uma tribo, conhecido por sua sabedoria e
transmissão de conhecimento; figura presente na África tribal que percorre a
savana para transmitir, oralmente, ao povo fatos de sua história; é o agente
responsável pela manutenção da tradição oral dos povos africanos, cantada,
dançada e contada através dos mitos, das lendas, das cantigas, das danças e
das canções épicas; é aquele que mantém a continuidade da tradição oral, a
fonte de saberes e ensinamentos e que possibilita a integração de homens e
mulheres, adultos e crianças no espaço e no tempo e nas tradições; é o poeta,
o mestre, o estudioso, o músico, o dançarino, o conselheiro, o preservador da
palavra. A palavra que, na cultura africana, é muito importante, pois
representa a estrutura falada que consolida a oralidade. O poder da palavra
garante a preservação dos ensinamentos desenvolvidos nas práticas essenciais
diárias na comunidade (MELLO, 2009, p. 149).

Essa incorporação das identidades negras através do recontar também aparece na protagonista mirim de Ponciá Vicêncio, já que ela só tem acesso à cultura dos seus, graças às histórias contadas por sua mãe, a griote Maria Vicêncio. É importante salientar que nas culturas africanas, também "existem mulheres contadoras de histórias que têm habilidade para cantar e recitar versos, são as griotes, chamadas djelimusso, na cultura mandingue" (MELLO, 2009, p. 150). Nota-se, então, que tanto a presença de Maria Vicêncio de Ponciá Vicêncio, como também de Maria-Velha de Becos da Memória na condição de griotes, revelam a tendência de Conceição Evaristo de deixar na narrativa evidências de uma escrita feminista.

Assim como nas tradições orais africanas, nas narrativas afro-brasileiras de Conceição Evaristo há também uma relação da palavra com o saber/conhecimento e a 
preservação das culturas negras. As personagens Ponciá Vicêncio e Maria-Nova simbolizam a tentativa de preservação da memória dos afrodescendentes. Como crianças, elas figuram o "herói privado" contra o aniquilamento da memória positiva de seus ancestrais e assimilam essa trajetória como "futuro inevitável":

Provavelmente, na vida adulta repetirá a memória aos filhos e à sua entourage. $\mathrm{O}$ aspecto específico do discurso que se constrói em sua história é transformar vidas comuns, banais, em elementos de uma história da vida privada em que valores positivos são absolutamente priorizados, transformando indivíduos comuns em heróis. Essa memória positiva, transmitida pela família, passa a ser o lugar positivo de sua vida. Constitui-se também, no lugar da permanência, garantindo elementos à construção do herói privado contra o aniquilamento de seus ancestrais, de suas gerações referenciais (NUNES, 2003, p. 36).

A poesia de Conceição Evaristo repete esse mesmo discurso romanesco a respeito da construção da infância. De modo que a rememoração, nos dois gêneros, simboliza a tentativa de resistência, é a proposta de uma memória significativa para as demais gerações de negros. Ela é resultado das vozes do ontem, e exemplo para as vozes do hoje. É a ressonância, os ecos da "vida-liberdade", e a criança é a promessa de esperança para mudar a história de silêncio, invisibilidade e dor, como bem podem ser lidos nos trechos do poema "Vozes-mulheres" (EVARISTO, 2008, p. 10-11) da obra Poemas da recordação e outros movimentos:

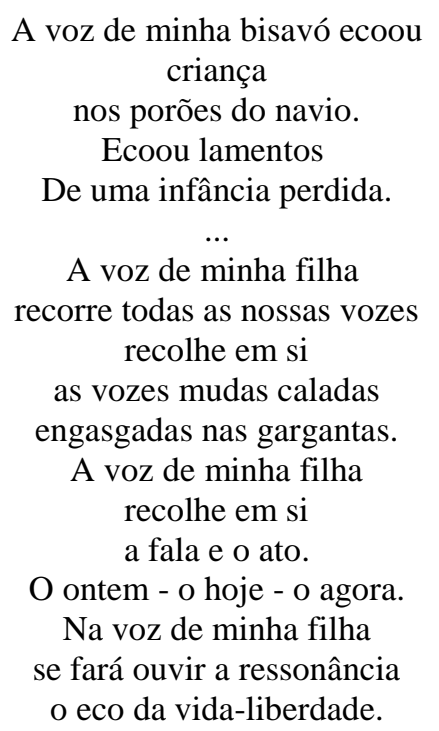

A voz da criança se refere à esperança de um reconhecimento social, a construção de uma nova versão da história do povo negro. Está depositada na criança a certeza de que ela fará ouvir com ressonância as vozes emudecidas e silenciadas. Elas são os "heróis" do futuro que ecoarão as memórias de resistência negra, pois já é tempo dos gritos serem ouvidos, porque enquanto o sofrimento estiver vivo na memória dos 
pequenos, procurarão, nem que pela força do desejo, a criação de outros destinos para si.

Elas serão as protagonistas no processo de "recompor o tecido cultural africano que se desteceu pelos caminhos, recolher fragmentos, traços, vestígios, acompanhar pegadas na tentativa de reelaborar, de compor uma cultura de exílio refazendo a sua identidade de imigrante nu" (EVARISTO, 2010, p. 132). A infância vai sendo desenhada por Evaristo como uma potência politizadora do grupo.

Mais claramente, em Becos da Memória, a escrita ou mesmo a literatura é tratada como o elemento que instrumentaria a criança (Maria-Nova) para resistir às opressões e inscrever a história do povo negro, agora contada por quem realmente a conhece, os afrodescendentes: "Sim, ela iria adiante. Um dia, e agora e agora ela já sabia qual seria a sua ferramenta, a escrita. Um dia, ela haveria de narrar, de fazer soar, de soltar as vozes, os murmúrios, aos silêncios, o grito abafado que existia, que era de cada um e de todos. Maria-Nova, um dia, escreveria a fala de seu próprio povo" (EVARISTO, 2010, p. 161). Maria-Nova parece ter a potência para as duas funções, a de "tradicionalista" e a de "griot"12: "Maria-Nova, à medida que aprendia, tornava-se mestra dos irmãos menores e das crianças vizinhas. Maria-Nova crescia, lia, crescia" (EVARISTO, 2010, p. 62).

Já em Ponciá, a memória dos negros se perpetuaria a partir da arte com o barro, que a protagonista fazia com a mãe. O Vô Vicêncio é o exemplo da memória individual e ao mesmo tempo coletiva que a menina eternizou em sua arte, já que "cada memória individual é um ponto de vista sobre a memória coletiva" (HALBWACHS 1990, p. 51). As características do boneco de barro, homem com braço cotó, marca os males que a escravidão trouxe ao povo negro, mas a arte em si, é também a memória de resistência (memória positiva) de toda a coletividade de africanos que foram escravizados no Brasil e seus descendentes, é a prova de que o negro não apenas representa a força que ajudou a tecer o Brasil, porque o Brasil é, também, a arte e cultura do negro:

Os ofícios artesanais são os grandes vetores da tradição oral. Na sociedade tradicional africana, as atividades humanas possuíam frequentemente um caráter sagrado ou oculto, principalmente as atividades que consistiam em agir sobre a matéria e transformá-la uma vez que tudo é considerado vivo. (B̂̂A, Hampaté, 2010, p. 185).

\footnotetext{
${ }^{12}$ Esclareço ao leitor que não afirmo que Maria-Nova seja ou será uma tradicionalista ou griot, mas que ao criar essa personagem entre outras aqui apresentadas a escritora homenageia e traz a memória do leitor uma das tantas Tradições Orais as quais são ricas e diversas.
} 
Enquanto alguns teóricos expõem que "o universo infantil guarda especificidades que o caracteriza como área sui generis nos estudos sociológicos. Suigeneris porque a sociedade lhe permite o lugar do que não tem voz, daquele que não tem fala" (NUNES, 2003, p. 27), nas criações de Conceição Evaristo a criança é valorizada pela sua capacidade de ouvir e ressoar a alteridade:

\begin{abstract}
Menina, o mundo, a vida, tudo está aí! Nossa gente não tem conseguido quase nada. Todos aqueles que morreram sem se realizar, todos os negros escravizados de ontem, os supostamente livres de hoje, libertam-se na vida de cada um de nós que consegue viver, que consegue se realizar. A sua vida, menina, não pode ser só sua. Muitos vão se libertar, vão se realizar por meio de você. Os gemidos estão sempre presentes. É preciso ter os ouvidos, os olhos e o coração abertos (EVARISTO, 2013, p. 103).
\end{abstract}

Fica evidente nas narrativas que a liberdade individual, seja de Maria Nova, Ponciá ou qualquer outra criança das tramas também pode ser o símbolo de uma conquista coletiva, é a realização de todo um povo, é a vitória individual que alcança a coletividade:

Se a memória coletiva tira sua força e sua duração do fato de ter por suporte
um conjunto de homens, não obstante eles são indivíduos que se lembram,
enquanto membros do grupo. Dessa massa de lembranças comuns, e que se
apoiam uma sobre a outra, não são as mesmas que aparecerão com mais
intensidade para cada um deles. Diríamos voluntariamente que cada memória
individual é um ponto de vista sobre a memória coletiva, que este ponto de
vista muda conforme o lugar que eu ali ocupo, e que este lugar mesmo muda
segundo as relações que mantenho com outros meios. Não é de admirar que
do instrumento comum nem todos aproveitem do mesmo modo. Todavia
quando tentamos explicar essa diversidade, voltamos sempre a uma
combinação de influências que são, todas, de natureza social
(HALBWACHS, 1990, p. 51).

Nas narrativas a memória coletiva e a memória individual se fortalecem, pois uma é suporte da outra, a individualidade identitária é construída com base na identidade coletiva, juntas formam o espaço de afirmação da identidade negra e a criança é sua guardiã em potência, o herói contra o extermínio da memória positiva de seus ancestrais.

\title{
3.2.1 As lentes das culturas africanas
}

A partir da leitura de que há uma referência aos griots por meio de algumas personagens e das narradoras das tramas, uma questão se impõe: o que justifica o uso das tradições africanas nessas narrativas? A leitura dessas narrativas a partir dessas referências pode ser legítima? As respostas a estas questões já foram dadas 
parcialmente, quando dito que as narrativas deslocam o foco da tradição ocidental para uma tradição "não-ocidental”. Elas rompem com a lógica eurocêntrica e centralizadora de que determinadas literaturas produzidas com determinadas estéticas são superiores e universais. Afastam-se das perspectivas epistemológicas hegemônicas em favor de uma perspectiva de descentramento, especificamente uma perspectiva "suplementar", ademais "diferentemente do complemento, afirmam os dicionários, o suplemento é uma "adição exterior"... O suplemento é a imagem e a representação da natureza. Ora, a Imagem não está nem dentro nem fora da natureza. Portanto, o suplemento também é perigoso para a razão, para a saúde natural da razão". (DERRIDA, 1973, p. 183). Assim essas narrativas estão fora do permitido pelas normas literárias por recorrerem aos seus próprios espaços culturais, periféricos do ponto de vista do centro.

A alusão à figura do griot representado por personagens e narradores não é o único registro importante das culturas africanas, nas narrativas de Evaristo. Em Ponciá Vicêncio, por exemplo, há mais dois elementos fortes na narrativa: o arco-íris/cobra celeste/, referência ao orixá Oxumaré e a figura da mulher alta, fina, transparente e vazia.

Os adjetivos "vazia" e "transparente", da mulher vista e admirada pela menina Ponciá, no milharal, suspendem as ordens/lógica da racionalidade, pois nessa lógica uma mulher não poderia ser "vazia e transparente". De modo que a denotação dessa figura mítica pode se aproximar das ideias de "Neutro" discutidas por Barthes (2003), uma vez que esse conceito carrega a ideia do elemento que "burla o paradigma" (BARTHES, 2003, p. 16). Antes de tentar esmiuçar o que seria o "Neutro" é necessário adiantar mais uma breve justificativa para aproximar a simbologia dessa mulher ao conceito de Neutro.

O fato é que o Neutro "suspende as ordens, as leis, as cominações, as arrogâncias, as intimações, o narcisismo, as exigências. Ele transgride a doxa do senso comum, a violência do preconceito (ele não é branco nem é preto). O neutro desvia a regra da normalidade, o estabelecido, o preestabelecido". E é o que parece ocorrer com a Mulher vazia e transparente, ela rompe a norma da normalidade. Essa mulher não seria o símbolo de uma cultura que rompe a "normalidade"? As culturas negras? Não seria o símbolo de um rompimento com uma literatura estabelecida?

Podemos dizer que ela não é o preto nem o branco. Não é branco porque está longe de ser vista pela positividade que o branco carrega socialmente e longe de ser o preto porque a negatividade que o termo transparece socialmente não corresponde com 
o que realmente a "mulher transparente" é, ou seja, há aí uma reclamação de uma denominação que não passa pela lógica racionalista. Então, como definir essa mulher?

Para responder essas questões devo avançar nas ideias de Barthes (2003) sobre o Neutro. O teórico diz haver uma correspondência mítica entre o incolor e o Neutro, e acredita em possíveis interpretações, valores investidos na oposição entre colorido e incolor. A cor estaria atrelada à festa, riqueza e à classe superior, diferente do Neutro (grisalha, camafeu) que estaria para a cotidianidade, uniformidade social. Ele contextualiza explicando que na Idade Média, cores vivas estavam associadas ao dinheiro e ao luxo e o "Neutro é associado miticamente, se não à pobreza, pelo menos ao não dinheiro, a não pertinência da oposição riqueza/pobreza" (BARTHES, 2003, p. 107).

Mas outra questão importante diz que o "incolor" ou Neutro tem um "verso", ele é uma superfície principal, rica, brilhante e colorida que é comumente escondida, diferente do reverso que é exposto, isto é, o verso do Neutro é escondido e o reverso é dado a ver. Há o lado transparente e o lado oculto. O oculto é rico e o transparente é pobre, ou pode ser visto como pobre dependendo da posição de quem vê. Então Barthes apresenta um problema: "Será que o Neutro é realmente uma superfície fraturável, separável, atrás da qual haveria riqueza, cor, sentido forte?" (BARTHES, 2003, p. 108). A mulher transparente e vazia de Conceição Evaristo não representa essa fratura? A fratura de uma ideia do que seriam os povos negros?

A mulher vista por Ponciá apresenta quatro qualificações reveladoras de uma fratura: alta, fina, vazia e transparente. Os predicativos alta e fina não estão em harmonia com vazia e transparente. Alta e fina passaria pela lógica da racionalidade (o reverso) e vazia e transparente é o desvio dessa lógica, é aquilo que não é exposto, que não é visto, mas existe. Seria como diz Barthes (2003) "momento do ainda não". O Neutro “como 'qualificante', ele se cola a um substantivo, a um ser, ele 'gruda' no ser...ele sela o ser como uma imagem imobilizadora" (BARTHES, 2003, p. 112). Não é assim a imagem dos negros brasileiros? A imagem de escravo não continua inerte, fixa, irremovível? "Eterna como Deus" (EVARISTO, p. 50, 2003). Para Barthes essa imagem permanente "muda sutilmente de aspecto dependendo, talvez de sentido, segundo a inclinação do olhar do sujeito" (BARTHES, 2003, p. 109). Isso significa que o Neutro não corresponde obrigatoriamente à imagem pobre, essencialmente depreciada, mas pode constituir um valor forte, ativo. 
Com a simbologia da Mulher transparente Evaristo defende o valor e a riqueza das culturas negras, aquela que não é vista no seu modo de ser, mas que está lá para ser contemplada por quem tem ou queira a mesma consciência da menina Ponciá.

A presença do arco-íris na trama parece representar o verso do Neutro figurado pela mulher transparente. $\mathrm{O}$ verso/arco-íris simboliza a riqueza das culturas negras e a resistência dos povos negros que se contrapõe ao reverso/transparência da mulher. Marcelo Costa Nunes e Rafael Alves em Oyé Orixá: Umbanda e a síntese dos princípios do branco, do vermelho e do negro (2009) trazem uma definição que ajuda a compreender o arco-íris/Oxumaré como a positividade do Neutro:

\footnotetext{
"O engendrado das águas que manifesta toda a beleza e todo o movimento". A exaltação do poder criador e transformador. O princípio divino que assegura a evolução e a continuidade da existência por meio do Princípio da Beleza convertido em aperfeiçoamento e regeneração (NUNES e ALVES, 2009, p. 132).
}

Segundo Pierre Verger (1986), contam as lendas de Ifá que Oxumaré era um babalaô (adivinho e sacerdote), nem sempre foi rico, tinha passado por escassezes e por isso era desprezado. Oxumaré era explorado por Olofin, o rei de Ifé, "seu principal cliente. Consultava-lhe a sorte de quatro em quatro dias, mas o rei remunerava seus serviços com extrema parcimônia e Oxumaré vivia num estado de semipenúria" (VERGER, 1986, p. 70). Lendo a narrativa de Ponciá a partir dessa mitologia fica evidente que a referência a esse orixá, no romance, é o reforço da denúncia à escravidão dos povos negros, mas também figura a força do negro para resistir às explorações.

A aparição do arco-íris na narrativa é o símbolo da força e da resistência, das tentativas de mobilidade do negro como também foi para Oxumaré: "Sua chegada final à glória e ao poder é simbolizada pelo arco-íris, que, quando aparece, faz as pessoas exclamarem: "Ora, ora, eis Oxumaré!". Isso mostra que ele é universalmente conhecido e, como a presença do arco-íris impede que a chuva caia, demonstra também a sua força” (VERGER, 1986, p. 70). A aparição do arco-íris, símbolo da riqueza, é o arquétipo da força e cultura do negro.

Mas não só isso, pois o Oxumaré/serpente é também o símbolo da continuidade e da permanência. Enrola-se em volta da terra para impedi-la de se desagregar. Sua presença sinaliza a reconstrução e a preservação das histórias e dos povos negros desagregados. E até mesmo é a alegoria de uma escrita afrodescendente como meio para a continuidade dessa memória. A criança seria protagonista desse processo de recomposição do tecido cultural africano, é quem deve recolher esses fragmentos para refazer a identidade negra. 
Em suma, o Neutro é a categoria ética para superar a marca intolerável do sentido ostensivo, do sentido opressivo. De modo que não poderia ser difícil dizer que as narrativas de Conceição Evaristo estejam imbricadas nesse Neutro. Ao fazer uso das lentes das culturas negras e questionar a visão depreciativa dessas culturas e até mesmo dos povos negros, Conceição Evaristo burla os paradigmas ocidentais de literatura e firma sua literatura nas bases do descentramento - no suplemento.

\subsection{A liberdade imperfeita}

Um dos principais filósofos do iluminismo, Jean-Jacques Rousseau, em Emílio, ou da Educação (1995), afirma que as crianças enfrentam restrições à sua liberdade, isso, já após o nascimento, representado pelos limites de movimentos impostos por faixas e panos colocados por todo o corpo, e seguem com os entraves impostos pelas instituições sociais.

A protagonista de Ponciá Vicêncio, no entanto, é desenhada inicialmente, pela narradora, como uma criança sem faixas e com força para realizar movimentos. A narrativa dá destaque ao poder de movimento e à ânsia por liberdade da menina Ponciá, símbolo da vontade e do desejo de andar, de auferir a liberdade e circular em busca de uma autonomia: "Um dia, a mãe com ela nos braços estava de pé junto do fogão a lenha, olhando a dança do fogo sob a panela fervente, quando a menina veio escorregando mole. Veio forçando a descida pelo colo da mãe e pondo-se de pé, começou as andanças" (EVARISTO, 2003, p.16).

Conceição Evaristo partilha da ideia de Rousseau (1999, p. 55), quanto à necessidade de "dar às crianças mais verdadeira liberdade e menos domínio, deixar que façam por si mesmas e exijam menos dos outros”. Quando começa a andar Ponciá precisa menos do outro, e essa "força" é o início do desenvolvimento do conhecimento e das condições para que possa dirigir a si mesmo. Porém, no decorrer da trama fica evidente que a autonomia da menina vai esvaindo-se ao passo que sua condição de descendente de escravo lhe é revelada.

Rousseau entende a liberdade do infante como algo natural da criança, porém chega a ser retirada da naturalidade pelas instituições e pelo preconceito. A liberdade da criança é limitada pela fragilidade imposta pela sociedade. O entrave imposto impossibilita a felicidade da criança, já que essa só pode ser feliz, de acordo com Rousseau, quando faz o que deseja e não quando está submetida ao desejo do outro. 
Com esse fundamento podemos dizer que o caso das crianças negras escravas ou descendentes de escravos, que vivem presas às chagas da escravidão é mais complexo ainda. Elas estão bem longe de alcançar essa felicidade, pois suas necessidades são bem maiores que o poder de realizá-las. Assim a trama figura uma "liberdade imperfeita" para as crianças negras. Rousseau explica:

\begin{abstract}
Antes que os preconceitos e as instituições humanas alterem nossas tendências naturais, a felicidade das crianças, bem como as dos homens, consiste no emprego de sua liberdade; mas essa liberdade, nas primeiras, é limitada pela fraqueza. Quem quer que faça o que deseja é feliz, se se basta a si mesmo: é o caso do homem vivendo em seu estado natural. Quem quer que faça o que deseja não será feliz se suas necessidades ultrapassarem as forças: é o caso da criança no seu estado. As crianças não gozam, mesmo em seu estado natural, senão uma liberdade imperfeita, semelhante a de que gozam os homens na sociedade( ROUSSEAU, 1999, p. 68).
\end{abstract}

Sem possibilidade de reação, quando humilhado pelo coronelzinho, o pai de Ponciá sente desejo de sair das terras do Senhor Vicêncio e lutar por uma vida melhor, porém a sociedade fez o homem negro semelhante aos infantes, mais fraco, "não somente tirando o direito que lhe tinha sobre suas próprias forças, como também as tornando insuficientes. Eis porque seus desejos se multiplicam na fraqueza da infância e eis o que faz a fraqueza da infância em relação ao adulto" (ROUSSEAU, p. 67).

Em Jean-Jacques Rousseau: a transparência e o Obstáculo, Starobinski recorda a infância de Rousseau, descrevendo-a a partir do termo "parecer", "malefício da aparência" e acaba por chamar essa infância de "perturbação brutal". Ele retraça a revelação traumatizante de Rousseau, em que é acusado injustamente de ter quebrado um pente. A este fato atribui uma importância decisiva na sua infância. Ele revela que "desde esse momento teria deixado de gozar de uma felicidade pura" (STAROBINSKI, 1991, p. 19).

O episódio, de acordo com Starobinski (o incidente do pente quebrado), provoca a "catástrofe (a queda), que destrói a pureza da felicidade infantil". Depois dessa ocorrência surge a injustiça, e a infelicidade torna-se um fato ou uma possibilidade. "Essa lembrança tem o valor de um arquétipo: é o encontro da acusação injustificada, Jean-Jacques parece ser culpado sem o ser realmente" (STAROBINSKI, 1991, p. 19). A infância é dividida entre o antes e o depois da queda, o momento de felicidade e o de infelicidade.

Ferretti (2004) reafirma a leitura de Jean Strarobinski sobre Rousseau, de modo claro e didático, pontua o incidente do pente quebrado como a passagem de um estado a outro: a infância para ela é o momento da vida no qual se é inocente e feliz, mas ainda na infância a felicidade infantil se esquiva, é perturbadora. Ela aponta para a catástrofe 
que destrói a pureza da felicidade infantil. A partir dessa queda, a injustiça, a infelicidade se aproxima ou é possível para a criança. Ela afirma, então, que as crianças passam por duas fases no período da infância. O primeiro momento é de felicidade e o posterior é de perda de felicidade (FERRETTI, 2004, p. 34).

O incidente do menino, pai de Ponciá, em parte é semelhante ao caso de Rousseau. O menino é visto injustamente como escravo, judicialmente não o era, mas socialmente ou na "aparência", como chamou Starobinski, tudo se encaminhava para lhe ser imputada tal carga. Ele tinha a obrigação de brincar com o coronelzinho "era o cavalo onde o mocinho galopava" (EVARISTO, 2003, p. 17). O problema da aparência se complica quando o coronelzinho exige que o menino abrisse a boca para que pudesse urinar dentro.

Inicia-se aí o processo da crise da infância para esse filho de escravos. A consequência dessa acusação é a descida do "véu" entre o menino e ele mesmo, ele "oculta sua natureza primeira, sua inocência" semelhante ao que registrou Starobinski referindo-se a Rousseau (1991, p. 22); a desconfiança para com o sinhozinho torna impossível a amizade entre os dois. As palavras de Strarobinski podem ser emprestadas para descrever bem a situação desse menino: “Os outros o desconhecem: o eu sofre sua aparência como uma denegação da justiça que lhe seria infligida por aqueles pelos quais queria ser amado" (STAROBINSKI, 1991, p. 21).

O evento marca o começo de uma "perturbação", um conflito infantil; inicia-se uma nova época, "uma nova era de consciência". Essa nova era se define por uma descoberta essencial, pois pela primeira vez "a consciência tem um passado" (STAROBINSKI, 1991, p. 21). Ele percebe sua condição de escravo, questiona a si mesmo e ao pai o porquê da sua condição de servo: "Se eram livres, por que continuar ali? Por que, então, tantos e tantas negras na senzala? Por que todos não se arribavam à procura de outros lugares e trabalhos?" (EVARISTO, 2005, p. 14).

No momento em que a felicidade infantil the escapa, ele reconhece o valor infinito dessa felicidade proibida para um menino pobre, negro, sem um lugar para chamar de seu e ainda descendente de escravos. A inocência desaparece da vida do menino, agora seus olhos podem ver com clareza a realidade que sempre foi:

Todos os vícios de nossas infâncias corrompiam nossa inocência e enfeitavam nossas brincadeiras. Até o campo perdeu aos nossos olhos esse atrativo de doçura e de simplicidade que chega ao coração. Parecia-nos deserto e sombrio; como que se cobria de um véu que nos ocultava-lhe as belezas. As almas não se encontram mais e têm prazer em ocultar-se. Tudo está perturbado, e a criança punida descobre essa incerteza do conhecimento de outrem, que se lamentará" (STAROBINSKI, 199, p. 20). 
O fato parece se repetir na construção da protagonista Ponciá. Ela passa por essas duas fases da infância segundo Rousseau, a inocência/felicidade e a transparência/infelicidade. A contextura narrativa expõe a menina a uma variação de sentimentos, os deslumbramentos e os medos. A criança Ponciá Vicêncio carrega no nome, o qual ela mesma chama de "vazio e distante", a reminiscência do poderio do Senhor Coronel Vicêncio, dono de terras e de homens.

O brincar já foi algo constante na vida da menina Ponciá. Mostrava-se satisfeita em ser menina, de ser ela própria. Gostava de tudo que envolvia sua infância. Mas a heroína chega ao desencantamento ao fim de uma fantasia, sua infância é interrompida. Seu pai tira-lhe o direito de brincar, corta o milharal (espaço em que brincava). Logo, corriqueiras angústias fazem Ponciá entrar num estágio de negação de si, de sua identidade. Resta-lhe o trabalho artesanal com o barro e o choro.

Infância curta, a menina chega cedo à vida adulta, a qual é marcada por uma situação de introspecção, angústia, momentos de silêncio, afastamento dos seus e de si mesma. Paraíso perdido da infância inocente e feliz, a não liberdade para executar atividades infantis conduz a menina à revelação da sua condição social, e assim "a queda" é configurada.

É com essa liberdade imperfeita que Conceição Evaristo representa as crianças negras de Ponciá Vicêncio: a menina Ponciá, e o pai de Ponciá quando menino e até mesmo o menino Luandi, que passou sua infância trabalhando com o pai na roça.

\subsection{O tempo e espaço social das crianças negras}

Apesar do reconhecimento histórico-social do conceito de infância (ARIÈS, 1981), já é proposta nas narrativas contemporâneas a tese do desaparecimento do dispositivo infantil ou conceito de infância. Ganha dimensão a ideia de que a infância já tenha admitido, na ficção contemporânea, outro conceito à noção tradicional de infância. "Não é de se admirar, portanto, que, entre as imagens da infância veiculadas pela literatura, já surjam aquelas que apostam numa não-infância para as crianças" (MATA, 2010, p. 77).

Um retorno às ideias do historiador Philippe Ariès em História social da criança e da família (1981) esclarece melhor essa tese. O estudo mostra-nos como a infância é socialmente apreendida, ao estabelecer um conjunto de discursos sobre a infância a 
partir de enunciações definidas culturalmente. "Desde que Ariès publicou, nos anos 1970, seu estudo sobre o aparecimento da noção de infância na sociedade moderna, sabemos que as visões sobre a infância são construídas social e historicamente: a inserção concreta das crianças e seus papéis variam com as formas de organização social” (KRAMER, 2003, p. 85-86).

Entende-se que os elementos que interferem no modo de configurar a infância são as características sociais e culturais, de maneira que existem várias infâncias cujas naturezas de socialização modificam-se consideravelmente.

Os estudos histórico-antropológicos apontam que a mesma compõe-se como uma dimensão importante na construção social, isto é, as formas da infância permitem a visualização de um tempo e espaço social. "Uma observação fundamental que deve ser feita é a de que o conceito de infância, contrariamente ao que se passa ao nível do senso comum, está longe de corresponder a uma categoria universal, natural, homogênea e de significado óbvio" (PINTO, 1997, p. 63). Não havia infância nas sociedades prémodernas, uma vez que não lhe era atribuída uma definição social e particular, aferida pelo período moderno.

As crianças são as grandes ausentes da história simplesmente porque, no chamado "passado" - da Antiguidade à Idade Média -, não existia este objeto discursivo a que chamamos "infância", nem essa figura social e cultural chamada "criança", já que o dispositivo de infantilidade não operava para, especificamente criar o "infantil"... Não é que não existissem seres humanos pequenos, gestados, paridos, nascidos, amamentados, crescidos - a maioria deles mortos, antes de crescerem -, mas é que a eles não era atribuída à mesma significação social e subjetiva (CORAZZA, 2002, p. 81).

O surgimento da noção de infância só foi possível mediante as transformações que principiaram na passagem para a sociedade moderna. Anteriormente, o curso da criança era de discriminação, marginalização e exploração. Essa marginalização era evidenciada na própria arte medieval em que se desconhecia a infância ou não havia interesse em concebê-la. Desse modo, a Idade Média, segundo Ariès (1981), não apresentava o sentimento em relação à criança, pois este era propriamente social e não sentimental.

Por outro lado, na Modernidade, surgem os sentimentos em relação à infância. O primeiro sentimento é o apego à infância e à sua particularidade expressa através da distração e da brincadeira:

Um sentimento superficial da criança - a que chamei de "paparicação" - era reservado à criancinha em seus primeiros anos de vida, enquanto ela ainda era uma coisinha engraçadinha. As pessoas se divertiam com a criança pequena como um animalzinho, um macaquinho impudico. Se ela morresse então, como muitas vezes acontecia, alguns podiam ficar desolados, mas a 
regra geral era não fazer muito caso, pois outra criança logo a substituiria. A criança não chegava a sair de uma espécie de anonimato (ARIÈS, 1981, p. 10).

O segundo sentimento é externo à família e diz respeito aos mais influentes representantes da sociedade moderna, os quais negam o sentimento de paparicação em favor da ideia de preservação e disciplina. Suas preocupações pautavam-se, sobretudo, na modelagem da criança, atrelada à ideia de dependência do adulto.

O segundo, ao contrário, proveio de uma fonte exterior à família: dos eclesiásticos ou dos homens da lei, raros até o século XVI, e de um maior número de moralistas no século XVII, preocupados com a disciplina e a racionalidade dos costumes. Esses moralistas haviam-se tornado sensíveis ao fenômeno outrora negligenciado da infância, mas recusavam-se a considerar as crianças como brinquedos encantadores, pois viam nelas frágeis criaturas de Deus que era preciso ao mesmo tempo preservar e disciplinar. Esse sentimento, por sua vez, passou para a vida familiar (ARIÈS, 1981, p. 163).

É com base na concepção moderna de infância que a compreensão contemporânea pensa a infância como o momento da vida que exige o cuidado da criança de forma específica e distinta do adulto. As crianças passam a ser notadas numa perspectiva diferente, pois lhes são atribuídas características peculiares que não haviam sido percebidas anteriormente e, assim, surge o início do conceito de infância. "O sentimento da infância não significa o mesmo que afeição pelas crianças: corresponde à consciência da particularidade infantil, essa particularidade que distingue essencialmente a criança do adulto, mesmo jovem. Essa consciência não existia" (ARIÈS 1981, p. 99).

A partir da modernidade, a infância passa a ser reconhecida pelo adulto como a fase que, além de ser distinta, caracteriza-se também pela necessidade de ser protegida e preparada para gerar adultos hábeis às novas requisições sociais. $\mathrm{O}$ sentimento da infância envolve o cuidado e a preocupação com a saúde, educação, bem estar das crianças. "No século XVIII, encontramos na família esses dois elementos antigos associados a um elemento novo: a preocupação com a higiene e a saúde física. $\mathrm{O}$ cuidado com o corpo não era desconhecido dos moralistas e dos educadores do século XVII" (ARIÈS, 1981, p. 164).

Essas representações são construtos históricos, produtos do contexto social no qual os sujeitos estão envolvidos. Portanto, são contingentes, acompanhando as transformações de um novo tempo social. Diante do exposto é questionável a presença do dispositivo infantil nas meninas e meninos negros das narrativas em questão, considerando o tempo social em que as personagens estão inseridas na trama. 
As representações da infância em Becos da Memória e Ponciá Vicêncio diferem do conceito moderno de infância apresentada por Ariès (1981). A infância nesses romances afro-brasileiros é a alegoria de um tempo e espaço social marcado pela marginalização, discriminação e exploração, de modo que a proteção projetada em torno da criança idealizada pela burguesia não tem como alcançar as crianças herdeiras de uma história de escravidão.

Isso significa dizer que assim como as crianças da Idade Média, é perceptível nas crianças das narrativas a falta de dispositivos para criar o infantil, o "dispositivo infantil não opera para especificamente criar a infância” (CORAZZA, 2002, p. 81). E essa definição se aproxima dos modelos sociais da infância branca de Ariès, pois a crianças negras encontra-se numa mudez maior em relação à criança branca que de alguma forma sempre foi retratada ao menos na história.

Cabe reiterar se o sentimento contemporâneo de infância atualizado pela ideia moderna de infância é ou não, uma prática associada à classe social e à raça. $\mathrm{O}$ dispositivo infantil alcança as crianças pobres e negras da narrativa afro-brasileira para criar o infantil? O surgimento de crianças pobres e negras na literatura afro-brasileira não coincidiria justamente com a negação da infância? Não seria apenas um elemento da infância burguesa e, portanto branca?

Em Ponciá Vicêncio as crianças aparecem na roça ajudando o pai; ajudando as mulheres a fazerem a colheita; ou aparecem no rio apanhando barro para fazer arte. Há poucos vestígios da proteção, do cuidado, preocupação com a saúde, educação, o bem estar e até afeto. O canto de Maria Vicêncio, o contar das histórias dos seus ancestrais para a filha Ponciá e a cena com a menina no colo são os pequenos vestígios dados pela narradora.

Em Becos da Memória as crianças pouco aparecem em cena de interação com os pais ou familiares, elas surgem mais em situação de distanciamento do que de aproximação, estão na rua, brincando de bola e de gude, pedindo esmola, lavando roupa nas torneiras públicas, ou em casa cuidando do lar e dos irmãos. Há, portanto, poucos sinais de afeto familiar e proteção.

Ao fazer um mapeamento cuidadoso das personagens infantis de Becos da Memória encontramos duas situações que podem explicar a aparição ou não do dispositivo infantil nas crianças negras da trama.

De um lado temos personagens que demostram afastar-se de uma educação com vias no afeto e cuidados como o Fuinha que espanca a filha Fuizinha, por tudo e por nada, mata a esposa na frente da filha e abusa sexualmente da criança; $\mathrm{O}$ menino 
Brandino, que ficou paralítico em um acidente, ao invés de ser posicionado no lugar de quem precisa de proteção e cuidados está na condição de quem cuida. Trabalha pedindo esmolas para sustentar a família. É significativa a figura antagônica de Tetê do Mané que vende a menina Nazinha de treze anos para servir às necessidades sexuais de um fornecedor de cigarros em troca de dinheiro para proteger outro filho.

Em outra situação, aparecem personagens como o Tonho, que às vezes, em vez de beber, gastava o dinheiro com doces e biscoitos para os filhos; o Bondade distribuía doces para as crianças da favela e lhe contava histórias e Tio Totó e Maria-velha demonstravam afeto ao contar histórias para Maria-Nova.

Essas duas posturas do tratamento à criança demonstram o cuidado das narradoras em apresentar uma infância complexa e fora do lugar comum, geralmente dado às crianças negras e pobres. Há crianças violentadas, exploradas e maltratadas, mas há as que recebem afeto da família e da comunidade.

Parece que a questão mais problemática que Evaristo apresenta não é tanto a questão do primeiro sentimento da infância, a paparicação e sim o segundo: a proteção, o cuidado com a educação, higiene, alimentação etc. Até porque o sentimento da paparicação está ligado à ideia de criança como objeto e não sujeito, apenas o ser engraçado que diverte, não é assim também com as representações literárias estereotipadas de negros bobos e engraçadas? A denúncia das narradoras não se concentra ou não parece se pautar na ausência de afeto e sim de proteção às crianças negras. Proteção que é negada, por vezes, na narrativa, tanto pelos familiares, quanto pelas instituições. Essas não garantem moradia, pelo contrário, expulsam as crianças das favelas, logo também da escola, não asseguram a alimentação e nem saúde.

A proteção geral não é negada, no entanto a proteção institucional não existe. Exemplo bem claro é o que também traz a narrativa de Carolina Maria de Jesus em Quarto de despejo (2005). Os filhos de Carolina, a Vera Eunice, o João e o José Carlos recebem até de modo exagerado afeto da mãe. A mãe defende os filhos das fofocas dos vizinhos, carrega a filha no colo quando está catando papelão, trabalha até doente e vive desejando ter mais dinheiro para comprar comida para os filhos e sapatos para a filha caçula. Porém, os filhos são desprovidos de qualquer proteção social, os olhares públicos estão fechados para as necessidades e especificidades das crianças pobres e negras como os referidos nessas obras afro-brasileiras. 


\subsubsection{As práticas do espaço}

Para falar de práticas de espaço foi eminente a fundamentação da obra $A$ invenção do cotidiano (1998) de Michel de Certeau. Sua importância é dada especialmente pela conceituação de lugar/espaço. Segundo o filosófo e historiador, um lugar é a ordem que por sua vez dissemina elementos nas relações de coexistência e está associada ao espaço, "em suma, o espaço é um lugar praticado. Assim a rua geometricamente definida por um urbanista é transformada em espaço pelos pedestres" (CERTEAU, 1998, p. 202). De modo que o espaço para Certeau é "existencial e a existência é espacial", portanto, a existência pressupõe a prática de um lugar e o lugar o qual é praticado define o lugar da existência do indivíduo no mundo, ou seja, o seu espaço social.

Ao considerar a premissa de que "as práticas de espaço tecem com efeito as condições determinantes da vida social" (CERTEAU, 1998, p. 175) e que "todo relato é um relato de viagem - uma prática de espaço" (CERTEAU, 1998, p. 175) faz-se necessária a verificação do "processo de apropriação do sistema topográfico" (CERTEAU, 1998, p. 177) traçado pelas crianças de Becos da Memória e Ponciá Vicêncio para uma possível identificação do espaço social ocupado pelas crianças dessas narrativas e a verificação do modo como esses espaços reforçam ou estabelecem suas identidades.

Para Certeau (1998) apesar da existência de uma ordem espacial que organiza um conjunto de possibilidades e proibições, pode haver também um caminhante que atualiza essas possibilidades e limites espaciais. "Deste modo, ele tanto as faz ser como aparecer. Mas também as desloca e inventa outras, pois idas e vindas, as variações ou as imposições da caminhada privilegiam, mudam ou deixam de lado elementos espaciais" (CERTEAU, 1998, p. 177). É o que ocorre com a comunidade da favela de Becos da Memória. Seus moradores já tinham vindo despejados de outras favelas e terras, fazendo surgir a atual favela e agora buscam reinventar outros espaços, porque novamente estão sendo expulsos da favela pelas autoridades responsáveis pela organização espacial.

Tanto em Becos da memória como em Ponciá Vicêncio tem-se a situação de crianças que percorrem os espaços da "possibilidade" e os espaços das "proibições". Essas personagens ultrapassam "os limites que as determinações do objeto fixaram para seu uso", ou em dadas situações transformam em outra coisa o significante espacial. Por um lado, negam-se a circular em alguns espaços de possibilidades determinadas pela 
ordem instituída, como também, por outro, buscam aumentar o número dos possíveis, os caminhos considerados lícitos ou obrigatórios. "Seleciona, portanto". (CERTEAU, 1998, p. 178).

Em Becos da Memória, a personagem Maria-nova ressignifica o espaço "favela", além de forçar a "transgressão do limite, desobedece à lei do lugar e acaba por representar à partida a lesão de um estado, a ambição de um poder conquistador, ou a fuga de um exílio, de qualquer maneira a 'traição de uma ordem'” (CERTEAU, 1998, p. 202).

A ressignificação espacial ocorre porque a personagem percorre os espaços da favela e vê a beleza na comunidade, tem prazer de circular entre a "torneira de baixo", e observar o cotidiano das pessoas, participar das rezas e festejos da comunidade, portanto o espaço da favela para a menina é o espaço da positividade e não apenas o espaço da decadência, pois é o lugar onde o seu povo está refazendo sua própria história. A transgressão da ordem espacial é cometida quando a menina começa a praticar um lugar que no tempo da narrativa não era permitido, o espaço da escola. Logo, Maria-Nova é a caminhante em potencial descrita por Certeau (1998) por atualizar as possibilidades espaciais.

Chamam atenção na narrativa dois espaços percorridos por Maria-Nova: "a torneira de cima" e a "torneira de baixo". Maria-Nova demostrava preferência por frequentar a "torneira de baixo". Ela significa na narrativa o espaço da fartura e do lúdico.

A "torneira de baixo" fornecia mais água, podia-se lavar roupa quase todo dia, as atividades domésticas eram realizadas de maneira mais rápida e prática, além de também ser o lugar da brincadeira. Por ser mais próxima à casa da menina era possível encontrar com outras crianças conhecidas, tinha o pé de amora e o botequim da Cema, em que ganhava doces. O lugar figurava o percurso da alegria.

A menina, como criança, circulava no espaço lúdico, a favela ressignificada, mas não estava isenta de enxergar como eram "pobres! Miseráveis talvez! Como a vida acontecia simples e como tudo era e é complicado" para esses descendentes africanos.

A "torneira de cima" carrega a simbologia narrativa de espaço do sofrimento, só era frequentada pela menina quando ela queria ver a realidade dura da favela, o sofrer. Esse espaço era a declaração explícita do cotidiano subalterno que o povo de MariaNova vivenciava, principalmente as mulheres: "a torneira, a água, as lavagens, os barracões de zinco, papelões, madeiras, e lixo. Roupas das patroas que quaravam ao sol. 
Molambos nossos lavados com o sabão restante. Eu tinha nojo de lavar o sangue alheio. E nem entendia e nem sabia que sangue era aquele" (EVARISTO, 2013, p. 29).

É possível compreender que a circulação de Maria-Nova nesses dois espaços antagônicos simboliza a resistência do negro, a criatividade de criar espaços além do imposto ou permitido.

Ao passo que simboliza o lugar do sofrimento, a "torneira de cima", também é o lugar do esclarecimento, lugar de uma consciência negra, a consciência de que o negro estava em baixo enquanto uma elite branca permanecia em cima esmagando-os, mas que era possível deixar de frequentar a torneira de cima e ressignificar a torneira de baixo.

Era o que a menina Maria-Nova fazia, caminhava errante pela favela em busca de um lugar. Ao ampliar as experiências espaciais buscava o espaço da dignidade, um espaço onde era possível o reconhecimento e as manifestações das identidades negras, isso só era possível em espaços ressignificados como a torneira de baixo. As ideias de De Certeau (1998) podem justificar os motivos do caminhar de Maria-Nova:

\footnotetext{
Caminhar é ter falta de lugar. É o processo indefinido de estar ausente e à procura de um próprio. A errância, multiplicada e reunida pela cidade, faz dela uma imensa experiência social da privação de lugar - uma experiência é verdade, esfarelada em deportações inumeráveis e ínfimas (deslocamentos e caminhadas), compensadas pelas relações e os cruzamentos desses êxodos que entrelaçam, criando um tecido urbano, e posta sob o signo do deveria ser, enfim, o lugar, mas é apenas um nome, a cidade. A identidade fornecida por esse lugar é tanto mais simbólica (nomeada) quando, malgrado a desigualdade dos títulos e das rendas entre habitantes da cidade, existe somente um pupular de passantes, uma rede de estados tomadas de empréstimo por uma circulação, uma agitação através das aparências dos próprios, um universo de locações frequentadas por um não-lugar ou por lugares sonhados (CERTEAU, 1998, p. 183).
}

Ao trabalhar com a ideia de retórica da caminhada, Certeau (1998) revela que "o caminhante constitui com relação à sua posição, um próximo e um distante, um cá e um lá” (CERTEAU, 1998, p.178). Para Maria-Nova o cá é a favela, o espaço permitido, o lá é a escola, frequentá-la é passar a fronteira da favela, misturar-se com os brancos, transgredir a ordem espacial. Porém, a favela que até então era legítima passa a ser ilegítima. O espaço da comunidade de Maria-Nova passa a ser interessante aos olhos da oficialidade, os moradores são expulsos de suas casas em um processo de desfavelamento e Maria-Nova deixa a escola, pois provavelmente ficaria longe de sua incerta futura morada. Assim, mais uma caminhada é imposta para o povo da favela, cabe a cada família inventar a prática de outros lugares. 
Um terceiro espaço parece necessário, mas que espaço estaria reservado para essas crianças? Como negociar mais um espaço? Quem disse que o homem negro não gosta de ter raízes? A falta de espaço é o grito denunciador do não espaço social. O negro não tem espaço na favela, nem na outra favela, nem na roça, pois é do Coronel Vicêncio, não vai ter na rua também, pois pode sujá-la. Onde é o lugar do negro na sociedade brasileira? Onde é o lugar do negro na literatura brasileira? A literatura do negro tem lugar? Parece que assim como a infância o espaço do negro é o da alheidade.

A narrativa de Ponciá Vicêncio inicia-se com o relato do espaço, o lugar praticado pela menina Ponciá. O rio é o primeiro relato de lugar exercido por ela, lugar de que retira o barro para fazer artesanato com a mãe; segue com o relato da roça, local em que a menina tinha acesso aos adorados pés de pequi, pés de coco-de-catarro, das canas e do milharal. Especialmente no milharal "divertia-se brincando com as bonecas de milho ainda no pé. Elas eram altas e, quando davam o vento, dançavam. Ponciá corria e brincava entre elas" (EVARISTO, 2003, p. 13); Quase em meados da narrativa nota-se o terceiro espaço expressivo da trama: Ponciá começa a frequentar a escola montada por missionários católicos que passavam pelo povoado.

Sobre os aspectos dos espaços das "possibilidades" e os espaços das "proibições", o primeiro e o segundo espaço da menina Ponciá eram permitidos. O lugar está relacionado a uma atividade do trabalho, no entanto a menina transforma-o em espaço lúdico, e do conhecimento de si. O rio não era apenas um lugar praticado para as atividades do trabalho. A menina transformou o trabalho com o barro em uma atividade prazerosa e lúdica. Também o torna um lugar significativo para o autoconhecimento. A menina, pela primeira vez, tem contato com o seu corpo e descobre a sua sexualidade:

\footnotetext{
Estava com uns onze anos talvez. Tinha acabado de passar por debaixo do arco-íris. Apavorada, deitou-se do outro lado no chão, e começou a apalpar o corpo para ver se tinha sofrido alguma modificação. Quando tocou lá entre as pernas, sentiu um ligeiro arrepio. Tocou de novo, embora sentisse medo, estava bom. Tocou mais e mais lá dentro e o prazer chegou apesar do espanto e receio (EVARISTO, 2003, p. 24).
}

Além de conhecer o corpo e descobrir a sexualidade, Ponciá usa o espaço para questionar o próprio nome e a identidade. Ela compreende que na sua assinatura havia a reminiscência do poderio do branco, sonha então com um novo nome, o que inicia o processo de negação do espaço praticado, pois ela aspira novos caminhos, deseja selecionar um espaço e sair da demarcação lícita e obrigatória:

Quando mais nova, sonhara até um outro nome para si. Não gostava daquele que lhe deram. Menina, tinha o hábito de ir à beira do rio e lá, se mirando nas águas, gritava o próprio nome: Ponciá Vicêncio! Ponciá Vicêncio! Sentia-se 
como se estivesse chamando outra pessoa. Não ouvia o seu nome responder dentro de si. Inventava outros. Pandá, Malenga, Quieti, nenhum lhe pertencia também. Ela, inominada, tremendo de medo, temia a brincadeira, mas insistia. A cabeça rodava no vazio, ela vazia se sentia sem nome. Sentia-se ninguém (EVARISTO, 2003, p. 19).

De igual modo, o pai de Ponciá (personagem sem nome), na infância, depois de ser obrigado a engolir a urina do mocinho, sinhô-moço, com quem era obrigado a passear nas terras do Coronel, brincar e fazer todas as suas vontades, protesta sua condição de escravo, deseja uma ruptura espacial e social, que não foi concretizada.

Ele chorava e não sabia o que mais lhe salgava a boca, se o gosto da urina ou
se o sabor de suas lagrimas. Naquela noite teve mais ódio ainda do pai. Se
eram livres, por que continuavam ali? Por que, então, tantos e tantas negras
na senzala? Por que todos não se arribavam à procura de ouros lugares e
trabalhos? Um dia perguntou isso ao pai, com jeito, muito jeito. Tinha medo
dos ataques dele. (EVARISTO, 2003, p. 17)

O outro espaço importante percorrido por Ponciá é também o espaço que simbolizava trabalho para algumas crianças, como o caso do seu irmão Luandi, o qual trabalhava na roça com o pai. Mas para Ponciá esse era o espaço do lúdico.

Os trajetos percorridos por Luandi, especialmente por Ponciá e Maria-Nova e outras personagens infantis das narrativas, não citadas aqui, os posicionam na condição de estrangeiro definido por Kristeva (1994). Por meio da autodenominação de estrangeiro as personagens passam pelo que Kristeva (1994) chama de consciência da diferença, ao passo que não avançam para o que a autora identifica como o término do sentimento da estrangeiridade a partir do reconhecimento de todos como também estrangeiros.

Estranhamente, o estrangeiro habita em nós: ele é a face oculta da nossa identidade, o espaço que arruína a nossa morada, o tempo em que se afundam o entendimento e a simpatia. Por reconhecê-lo em nós, poupamos de ter que detestá-lo em si mesmo. Sintoma que torna o "nós" precisamente problemático, talvez impossível, o estrangeiro começa quando surge a consciência de minha diferença e termina quando nos reconhecemos todos estrangeiros rebeldes e às comunidades (KRISTEVA, 1994, p. 9).

Dizer que todos são estrangeiros é afirmar que de algum modo todos são iguais. Nas narrativas não é possível a concepção desse reconhecimento. O espaço social ocupado pelos meninos e meninas negras e também, a consciência dele, não os habilitam a reconhecerem que o menino branco, os Coroneizinhos das casas-grandes, são tão descompensados quanto eles para receber de igual maneira a figuração de estrangeiros, de Outro, pois na verdade o outro é o negro em relação ao branco.

Ao representar crianças negras como estrangeiras, as narradoras das tramas entram em choque com o que Kristeva (1994) questiona: o estrangeiro, que foi o 
inimigo nas sociedades primitivas, pode desaparecer na sociedade moderna? Ao levarmos em conta as crianças de Evaristo como "estrangeiras", no sentido de ser o outro, consideramos também que as crianças negras (estrangeiras), ainda constituem-se “inimigas”, ameaça à sociedade branca. Isso fica evidente em Ponciá Vicêncio, quando o pai de Ponciá tem o seu processo de apreensão da leitura encerrado pelo Coronelzinho, que subestimava a capacidade do negro de aprender a ler, mas que no fundo tinha medo do que o menino poderia fazer se obtivesse consciência de sua própria opressão:

\begin{abstract}
A humilhação sofrida pelo personagem não se restringia ao sequestro da cidadania e ao letramento. Mesmo no período posterior à Lei Áurea, a criança negra, além de servir de montaria para o filho do patrão, tem ainda que aparar com a boca o mijo do sinhô-moço... A passagem explicita o dialogismo do texto com a tradição literária afro-brasileira e retoma a cena de Machado de Assis em que o menino Brás Cubas faz do escravo Prudêncio seu cavalo de brinquedo, ampliando-a, porém, para um nível inédito de violência (CAMPOS e DUARTE, 2011, p. 210).
\end{abstract}

O menino Negro Alírio de Becos da Memória, por sua vez, representava ameaça ao Coronel Jovelino, este, muito esperto, não nega o direito às letras ao menino, mas, ao contrário, contrata professora particular para ele, em sinal de diplomacia, disfarçando, assim, a opressão exercida por ele contra a criança.

Fica claro que nesses romances a infância é o espaço da alheidade, da outredade (condição de ser um outro, alguém excluído das esferas de poder econômico, social e político), da exclusão em distintas esferas da vida social: cultura, economia, epistemologia, estética, ética, jurídica, política (KOHAN, 1999, p. 62). Essa "alheidade", “outredade" é notada na própria palavra 'infância' que remonta a ideia daquele que não possui linguagem, no entanto, o que encontramos, na verdade, nessas narrativas, são personagens infantis falantes, mas também conscientes dessa fala.

\title{
3.5 A morte simbólica da infância
}

Nesse momento pretende-se analisar os traços narrativos que evidenciam o encurtamento e/ou, simbolicamente, a morte da infância, haja vista a ausência do sentimento em relação à infância apontada por Ariès (1981) e observada em algumas personagens infantis dos romances em estudo.

Um caso em especial é do menino Beto, de Becos da Memória. A trama imprime a imagem de uma criança que passa por um envelhecimento precoce. Com a mãe presa 
e o avô paralítico, o garoto assume as responsabilidades de cuidar da limpeza da casa, da educação dos irmãos e até mesmo de trabalhar.

O resultado não podia ser outro, "o menino estava envelhecido! Perdera todas as feições de criança! Estava adulto, muito adulto. Em poucos meses, sete somente, o menino parecia que ganhara anos e anos de vida" (EVARISTO, 2013, p. 148). Como narrado, Beto cresce repentina e violentamente, um menino que até ontem era moleque, vira adulto de um dia para o outro, a ponto de mostrar o cansaço no rosto. A morte da infância de Beto é assim marcada, em vários momentos da narrativa.

A composição da infância do personagem Beto nos leva à discussão da definição de dor dada por Rousseau (1999, p. 23), a qual traz a lume a ideia de duas dores que o homem fatalmente irá sentir. A "dor da alma" e a "dor física", isto é, "o destino do homem é sofrer em qualquer época. O próprio cuidado de sua conservação está ligado à dor. Felizes os que só conhecem na infância os males físicos, males bem menos cruéis, bem menos dolorosos do que outros... somente as da alma suscitam o desespero".

Com essa afirmação Rousseau acaba por dar medida valorativa a uma dor em relação à outra, de modo que a experiência de uma dor física é menos intensa que uma dor psicológica. Essa valoração não é questionada pela narradora de Becos, mas ela apresenta a personagem Nazinha, a qual experimenta uma dor diferente do menino Beto, a dor da alma. A menina é vendida pela mãe e torna-se objeto sexual do seu comprador (EVARISTO, 2013, p. 57-58).

Assim, quem parece não concordar com Rousseau é a mãe de Nazinha, ela transporta a filha antes do tempo para a vida adulta. "Dando-lhe maior necessidade do que ela tem, não aliviando sua fraqueza, antes a aumenta. Aumenta-a ainda exigindo dela o que a natureza não exigia, submetendo às suas vontades o pouco de forças que ela tem para atender as próprias" (ROUSSEAU, p. 68). A mãe provoca o apagamento da infância da filha para atender a do filho doente. A venda da filha decorre da busca da cura para a dor física desse filho, uma vez que o dinheiro da venda da menina oportunizaria a saúde da outra criança.

Essa mãe certamente seria condenada pela perspectiva de Rousseau a qual afirma que "ninguém tem o direito, nem mesmo o pai de mandar a criança fazer algo que não lhe é útil" (ROUSSEAU, 1999, p. 68).

A menina Nazinha não sabia reconhecer o seu lugar social de criança, a mãe que tinha a ciência lhe impõe a ordenança: "Nazinha acompanhe o moço". A mãe acaba por indicar o caminho de dor, a menina torna-se mulher antes do tempo. "o homem avisado 
sabe manter-se em seu lugar; mas a criança, que não conhece o dela, nele não pode manter-se... cabe aos que governam mantê-la em seu lugar" (ROUSSEAU, 1999, p. 68).

Ferretti (2004) apropria-se do termo roussoriano, "ilustração", para explicar como ocorre o término da infância. A leitura do teórico explicita que "ilustração" é a saída da infância, mais especificamente a "saída do homem de sua minoridade pela qual ele mesmo é culpado. Minoria é a incapacidade de servir-se de seu entendimento, mas na falta de decisão e de coragem para servir-se do seu sem condução de outrem" (FERRETTI, 2004, p. 23). Então a saída da infância se dá pela negação de ser conduzido pelo outro, a qual é concretizada por atitudes de autonomia.

Negro Alírio de Becos da Memória representa a vontade de ser conduzido pelo seu próprio saber, mostra insatisfação de ser submisso e aceitar passivamente os desejos do Coronel Jovelino. O menino cresce e adquire o poder da linguagem. Agora de posse do discurso vai enfrentar o coronel, pois o "moleque havia virado homem, uma espécie de líder do povoado". Além disso, ele amplia esse conhecimento para os outros meninos.

A narrativa também estabelece o desenvolvimento da linguagem como o elemento factível da saída de Negro Alírio da infância para a vida adulta. Para Ferretti (2004, p. 11), sair da infância é dar "um giro no campo da palavra e da linguagem e, portanto, uma outra posição subjetiva". Logo, "esse giro de posição discursiva é a própria condição de possibilidade de que venha a ex/istir - existir fora de si - um tempo de infância, um tempo de espera a ser fruído por seres pequenos que, no entanto, sonham em serem grandes".

Em Ponciá Vicêncio a passagem da narrativa que mais caracteriza a morte do sentimento da infância é o corte do milharal. A puerícia é encerrada, as vivências da menina Ponciá passam a ser como as dos adultos negros, diariamente é submetida à injustiça social, conhece a dor e a (in) felicidade tanto ou mais que o adulto e experimenta o labor do trabalho.

A composição dessas personagens infantis contribui para compreendermos a ideia de que a infância nesses romances é estreitamente cerceada. Instaura-se então uma nova concepção de infância, determinada por uma ordem socioeconômica e cultural e destituída do lúdico que com que frequentemente é representada. 


\subsubsection{O retorno a infans: a alegoria da origem, retorno à origem/ao início da fala}

Rousseau alia a noção de infância à ideia de um estado ao qual se pode retornar e retroceder: "Éramos feitos para sermos homens; as leis e a sociedade nos mergulharam novamente na infância" (ROUSSEAU, 1999, p. 23).

A leitura de Ferretti sobre Lacan permite essa compreensão, o mesmo define a infância como "um estado do qual se deve sair e ao qual se pode retroceder ou permanecer nele, sem avançar" (FERRETTI, 2004, p. 24).

Em Ponciá Vicêncio vemos tanto a saída da infância (antecipada) como também o retorno para esta. A saída é percebida quando vemos a criança perder na narrativa, o elemento que representa sua inocência, quando o direito de brincar e a proteção e o cuidado the são negados, e quando o espaço da brincadeira lhe é impossibilitado. A infância se distancia da personagem. O retorno à infância ocorre quando, depois de uma frustrada vida na cidade, a protagonista se torna um "sujeito sobre o qual se deve agir" (FERRETTI, 2004, p. 24) é conduzida pelo irmão e pela mãe até as águas. A infância é suplantada, esse retorno é entendido como o retrocesso.

Alegoricamente essa saída da infância e esse retorno são muito significativos para compreendermos as narrativas de Evaristo. Ao buscarmos nos principais estudiosos da infância uma definição para esse conceito, deparamo-nos com uma incompletude, pois "não há uma palavra que contemple o significado real de infância" (KOHAN, 2007). A exclusão da infância começa pela exclusão da palavra, uma questão antiga, que segundo Kohan remonta-se aos gregos do Período Clássico:

\footnotetext{
Percebemos, então, que a etimologia latina da palavra "infância" reúne as crianças aos não- habilitados, aos incapacitados, aos deficientes, ou seja, a toda uma série de categoria que, encaixadas na perspectiva do que ela "não têm", são excluídas da ordem social. Dessa maneira a infância está marcada desde a sua etimologia por uma falta não menor, uma falta que não pode faltar, uma ausência julgada inadmissível, a partir da qual uma linguagem, um direito e uma politica dominantes consagram uma exclusão. Em razão de um falta, a infância ficou fora, assim como à deficiência, a estrangeiridade, a ignorância e tantos outros faltosos (KOHAN, 2007, p. 101).
}

Diferentemente da concepção Kantiana em que a infância está atrelada à minoridade, no sentido metafórico de vida sem razão, obscura, sem conhecimento ou representação, "oposto das luzes, a falta de resolução e coragem no uso das próprias capacidades, a consagração da heteronomia" (KOHAN, 2007, p.109). É intenção das narradoras desses romances apresentar infâncias em que "a criança é um outro marginalizado - deveríamos dizer o primeiro outro marginalizado, já que a infância 
sempre vem antes do ciclo da vida. Assim sendo, a criança possui o ambíguo status de estranho privilegiado, a voz oriunda das margens"(KOHAN, 1999, p.11). Objetivam, também, criar espaços na narrativa para que de alguma forma essas vozes tenham destaques, além de fomentar artifícios para que ela possa ser ouvida e respondida. $\mathrm{O}$ resultado é a construção de narrativas que pensam a infância de crianças negras e problematizam seu espaço.

As infâncias apresentadas por Conceição Evaristo desafiam a tradição literária ao priorizar a questão do papel social designado para as crianças, e oferecem elementos para pensar suas condições de crianças negras. Ela mostra a exclusão não a reforçando, mas mostrando a possível capacidade de resistência na infância. Em suma, a visão que se tem na literatura afro-brasileira de Conceição Evaristo é pensar a infância a partir do que ela tem, e não do que lhe falta: com presença; autonomia; como afirmação, e não como negação, como força, e não como incapacidade.

O resultado das análises dos romances conduz à consideração de que a estética romanesca de Conceição Evaristo privilegiou a representação da infância. A escritora não vela as dificuldades que as crianças negras passam, porém sua obra se destaca mesmo pela proeza de não tratar as crianças como meras vítimas sociais, mas por negociar a representação apresentando critérios do caráter infantil, o qual se distancia das concepções de Ariès ("infância protegida"). Também, não é uma infância passiva, determinada pela ausência de "linguagem" (AGAMBEN, 2005) ${ }^{13}$, de consciência social ou conhecimento.

Os trajetos das personagens infantis de Conceição Evaristo na verdade simbolizam a história de uma coletividade, os povos negros brasileiros, povos que sempre foram vistos como infantes, sem razão e sem coragem. Ou que foram obrigados a retornar à condição de infante mediante a escravidão e os resquícios dela.

Assim como a palavra 'infância' está relacionada à ausência daquilo que o adulto tem, a uma falta, a uma incapacidade, a expressão 'negro' sempre esteve associada a elementos negativos, ao inferior, à diferença ou à falta em relação ao branco. De modo que, assim como as crianças, os negros estão encaixados numa perspectiva do que eles não têm, estando de igual modo, excluídos da ordem social. Nesse sentido as tramas denunciam o retorno forçado, obrigatório, do negro à condição

\footnotetext{
${ }^{13}$ A infância em Agamben é pensada como ausência e busca da linguagem sem origem: "A aposta da infância é que, ao contrário, seja possível uma experiência da linguagem que não seja simplesmente uma sigética ou uma insuficiência dos nomes, mas da qual se possa, ao menos até certo ponto, indicar a lógica e exibir o lugar e a fórmula" (AGAMBEN, 2005, p. 13). A infância é o lugar que privilegia o silêncio, "o não-poder-dizer da infância" (AGAMBEN, 2005, p. 77).
} 
de infante. Em contraponto, coloca-o no seu devido lugar, no lugar da resistência, do reconhecimento identitário, no lugar da consciência.

Assim, ao representar crianças em seu estado primeiro de felicidade as narradoras estão sinalizando para a história do negro antes de conhecer a amarga escravidão. A queda da infância é, portanto o momento em que os mesmos são condicionados a escravos. Pode-se entender que a queda ou a saída da infância é a figuração de todas as chagas vivenciadas pelos ancestrais negros. Enfim, o retorno ao infans representa a condição atual do negro, em que a sociedade racista brasileira teima em deixá-lo na subalternidade.

Nessa alegoria temos uma revisão histórica do trajeto do povo negro com as situações problemáticas que passaram, mas ela não alimenta o lamento da senzala, as narradoras põem em cena crianças com liberdade para falar, pensar e agir. O objetivo maior das narrativas é mostrar a resistência de crianças negras que simboliza a resistência dos povos negros, os quais não se conformaram com a ordem social nem assemelharam ou assimilaram essa ordem. Assim, essas obras podem ser consideradas referências de personagens negras infantis que criaram mecanismos de ruptura de silêncio e padrões impostos aos negros pela hegemonia racial. Essas narrativas são importantes especialmente porque contribuem para o surgimento de novas concepções de infância no contexto pós-colonial. 
(...) em se tratando de um ato empreendido por mulheres negras (...) escrever adquire um sentido de insubordinação.

Conceição Evaristo

O que levaria determinadas mulheres, nascidas e criadas em ambientes não letrados, e quando muito, semi-alfabetizados, a romperem com a passividade da leitura e buscarem o movimento da escrita?

Conceição Evaristo

\section{O lugar da infância}


A partir do passeio trilhado nos romances de Conceição Evaristo, assim como dos objetivos que perseguimos nesta pesquisa, constatamos que a temática da infância não só surge como elemento recorrente nos romances da autora, mas permeia grande parte de sua obra. Em muito de sua poesia e contos esse enfoque aparece, como é possível ser constatado no conto Olhos d'água publicado nos Cadernos Negros volume 28 (2005):

\begin{abstract}
Às vezes, as histórias da infância de minha mãe confundiam-se com as de minha própria infância. Lembro-me de que muitas vezes, quando a mãe cozinhava, da panela subia cheiro algum. Era como se cozinhasse ali, apenas o nosso desesperado desejo de alimento. As labaredas, sob a água solitária que fervia na panela cheia de fome, pareciam debochar do vazio do nosso estômago, ignorando nossas bocas infantis em que as línguas brincavam a salivar sonho de comida. E era justamente nos dias de parco ou nenhum alimento que ela mais brincava com as filhas. Nessas ocasiões a brincadeira preferida era aquela em que a mãe era a Senhora, a Rainha. (EVARISTO, 2005, p. 29).
\end{abstract}

O ponto comum dessas infâncias gira em torno das dificuldades sociais dos meninos e meninas afrodescendentes e da resistência engendrada por eles. Assim, o que nós propusemos nessa pesquisa foi questionar as pretensões das narradoras dessas tramas ao tecer a infância de crianças negras e verificar quais infâncias são apresentadas nas narrativas para então compreendermos que discurso é produzido a partir dessas infâncias.

Sobre o que pretendem as narradoras dos romances, compreendemos que a forma de apresentação das personagens infantis negras marcadas pela vivência da escravidão e da pós-escravidão sinaliza para uma literatura fundamentada numa estética de ruptura, logo, por uma estética fraturada. Trata-se da literatura afro-brasileira, a qual rompe com uma tradição literária hegemônica, com o projeto de "nação", uma vez que o negro não está representado legitimamente nessa ideação. São narrativas que se projetam para fora do limite permitido, ao representar esse grupo subalterno. Assim como a personagem Maria-Nova de Becos da Memória, que se projetou para fora da favela e teimosamente foi à escola. Essas narrativas recorrem aos próprios espaços culturais, periféricos ao ponto de vista do centro, em busca de uma singularidade e autonomia que lhe garantam uma invenção de um campo literário diferente.

O modo de representação escolhido por essas narradoras fica claramente evidente como aquela dependente do sujeito, não é possível a neutralidade do sujeito representante, pois as narrativas partiram de um lugar de voz socialmente demarcado. $\mathrm{O}$ que não significa, no entanto, que as tramas reflitam diretamente o real, ou mesmo refratem o real, pois o discurso artístico constitui a refração de uma refração, ou seja, 
uma versão mediada de um mundo sócio-ideológico que é texto e discurso (SHOHAT e STAM, 2006, p. 264).

A perspectiva autoral mirou na representação social cotidiana da criança negra, mas não se mostrou capaz de trazê-la à plenitude de seu sentido. Houve uma representação de algumas das perspectivas e não a ideia totalizante das crianças negras brasileiras. A autora não alimentou um realismo "corretivo", como descrito por Shohat e Stam (2006).

A utilização de referências ao real foi apenas uma orientação e não uma modelação, logo que os romances configuram uma perspectiva de realismo que não é a representação do real, mas parte de um ponto de vista realista da autora. A referência ao real é também o modo como essa literatura se posiciona para dar entrada ao seu leitor ideal, o leitor afro-brasileiro. A constituição da ficção de Evaristo, como ela mesma já afirmou, se realiza em diálogos com o mundo preexistente, do qual retira elementos que serão reformulados a partir de uma linguagem específica:

\begin{abstract}
E, depois, confesso a quem me conta, que emocionada estou, por uma história que nunca ouvi e nunca imaginei para nenhuma personagem encenar. Portanto, estas histórias não são totalmente minhas, mas quase que me pertencem, na medida em que, às vezes, se (com) fundem com as minhas. Invento? Sim, invento, sem o menor pudor. Então, as histórias não são inventadas? Mesmo as reais, quando são contadas. Desafio alguém a relatar fielmente algo que aconteceu. Entre o acontecimento e a narração dos fatos, algumas coisas se perdem e por isso se acrescenta. $O$ real vivido fica comprometido. E, quando se escreve, o comprometimento (ou o não comprometimento) entre o vivido e o escrito aprofunda mais o fosso. Entretanto, afirmo que, ao registrar estas histórias, continuo no premeditado ato de traçar uma escrevivência (EVARISTO, 2011, p. 10).
\end{abstract}

É por meio desse vínculo com o mundo empírico que é possível fazer a leitura do mundo ficcional, pois ele fornece os modelos de sua estrutura, inclusive a experiência do autor (escrevivência). Os romances marcam um espaço e tempo de uma história lesada por exclusões e subserviência, de forma que ficção e realidade se imbricam nas narrativas numa aflorada escrita com linguagem que marca o sofrimento, porém numa lírica incisiva.

Em relação ao ideal de infância tramado por Conceição Evaristo nas narrativas em estudo, foi perceptível que as infâncias concebidas nessas obras se afastam das concepções de Agamben (2005) no que diz respeito ao "não- poder- dizer da infância" (p. 77), a infância como um lugar que privilegia o silêncio, a infância como ausência.

A análise minuciosa dos romances nos mostraram que as personagens infantis negras são representadas com força, liberdade e autonomia, com espaço para falar. $\mathrm{O}$ contrário só ocorre porque o espaço social ocupado por essas crianças dissipa essa 
liberdade e assim uma "liberdade imperfeita" é figurada para essas personagens. A liberdade natural do infante é retirada pelas instituições e pelo preconceito, ou seja, ela é limitada pela fragilidade imposta pela sociedade. Nesse contexto elas estão longe de alcançar a felicidade, pois suas necessidades são maiores que o poder de realização.

Em suma, o que vemos é a narração de personagens infantis com uma consciência do seu estado social, percebendo suas condições, questionando os motivos da subserviência, além de ainda reconhecer o valor da felicidade, do espaço proibido para o infante negro e pobre. Nesse momento a infância parece se afastar como também a inocência passa ao largo, sendo interrompida no momento em que a consciência de sua condição social lhe é revelada.

Assim, as representações da infância em Becos da Memória e Ponciá Vicêncio diferem do conceito moderno de infância apresentado por Ariès (1981). A infância nesses romances afro-brasileiros é a alegoria de um tempo e espaço social marcado pela marginalização, descriminação e exploração, de modo que a proteção projetada em torno da criança idealizada pela burguesia não tem como alcançar as crianças herdeiras de uma história de escravidão. Há a falta de dispositivo para criar o infantil. Mata (2010, p.77) confirma esse pressuposto quando diz que entre as imagens da infância veiculadas pela literatura há as que apostam numa não infância.

O discurso guardado nessa infância apontada por Evaristo é a metáfora de que a sociedade brasileira faz o homem negro semelhante ao infante, além de tirar o direito sobre suas forças, torna-as insuficientes. Assim como a infância, o espaço do negro é o da alheidade, da outredade. Os povos negros brasileiros, povos que sempre foram vistos como infantes: sem razão e sem coragem. Ou que foram obrigados a retornar à condição de infante mediante a escravidão e os resquícios dela. E sempre tiveram sua identidade negra associada ao negativo, ao inferior, à diferença ou à falta em relação ao branco. De modo que, assim como as crianças, os negros estão encaixados numa perspectiva do que eles não têm, estão de igual modo, excluídos da ordem social. Nesse sentido, as tramas denunciam o retorno forçado, obrigatório, do negro à condição de infante. Em contraponto, coloca-o no seu devido lugar, no lugar da resistência, do reconhecimento identitário, no lugar da consciência.

Essas narrativas objetivam, também, criar espaços para que de alguma forma essas vozes tenham destaque, além de fomentar artifícios para que elas possam ser ouvidas e respondidas. O resultado é a construção de tramas que pensam a infância de crianças negras e problematizam seu espaço. 
Em linhas gerais, finalizamos ressaltando que as infâncias apresentadas por Conceição Evaristo desafiam a tradição literária ao priorizar a questão do papel social designado para as crianças, e oferecem elementos para pensar suas condições de crianças negras. Ela mostra a exclusão não a reforçando, mas mostrando a possível capacidade de resistência na infância. Em suma, a visão que se tem na literatura afrobrasileira de Conceição Evaristo é a de pensar a infância a partir do que ela tem, e não do que lhe falta: com presença, autonomia; como afirmação, e não como negação; como força, e não como incapacidade. 


\section{Referências}

AGAMBEN, Giorgio. Infância e história. Belo Horizonte: Editora da UFMG, 2005.

ARIÈS, Philippe. História social da criança e da família. 2. Ed. Rio de Janeiro: Guanabara Koogan, 1981.

BA, Hampaté Amadou. A tradição viva. In: Ki-ZEBO, Joseph (Editor), História geral da África, I: metodologia e pré-história da África. - $2^{\mathrm{a}}$ edição Ver. - Brasília: UNESCO, 2010.

BARTHES, Roland. O Neutro. Tradução de Ivone Castilho Benedetti. São Paulo: Martins Fontes, 2003.

Mitologias. Tradução de Rita Buongermino, Pedro de Souza e Rejane Janowitzer. $7^{\text {a }}$ edição - Rio de Janeiro: DIFEL, 2013.

BARBOSA, Marcio. Questões sobre Literatura Negra. In: Reflexões sobre a Literatura Afro-Brasileira. Quimlombhoje, São Paulo, Conselho de Participação e Desenvolvimento da Comunidade Negra do Estado de São Paulo, 1985.

BARBOSA, Maria José Somerlate. Prefácio. Conceição Evaristo. Ponciá Vicêncio. Belo Horizonte: Mazza, 2003.

BERND, Zilá. Introdução à literatura negra. São Paulo: Brasiliense, 1988.

Depoimento. In: DUARTE, Eduardo de Assis e FONSECA, Maria Nazareth Soares. Literatura e afrodescendência no Brasil: antologia crítica. Belo Horizonte: Editora UFMG, 2011, v.4, p.149-157.

BLOOM, H. O cânone ocidental. São Paulo: Objetiva, 1995.

BOURDIEU, Pierre. As regras da arte: gênese e estrutura do campo literário. Tradução Maria Lucia Machado. São Paulo: Companhia das Letras, 1996.

BROOSKSHAW, David. Raça e cor na literatura brasileira. Porto Alegre: Mercado Aberto, 1983.

BUCKINGHAM, David. Crescer na Era das Mídias: após a morte da infância. Tradução de Gilka Girardello e Isabel Orofino. Florianópolis. 2006. Título original: After the death of childhood: growing up in the age of eletronic media. Trabalho não publicado.

CERTEAU, M. de. A invenção do cotidiano: 1, Artes de fazer. Petrópolis: Vozes, 1998.

COMPAGNON, Antoine. O demônio da teoria: literatura e senso comum. Tradução de Cleonice Paes Barreto Mourão. Belo Horizonte: UFMG, 1999.

CORAZZA, Sandra Mara. Infância e educação - era uma vez - quer que conte outra vez? Petrópolis: Vozes, 2002. 
COSTA LIMA, Luiz. Mímisis: desafio ao pensamento. Rio de Janeiro; Civilização Brasileira, 2000.

Fresta: a teorização em um país periférico. Rio de Janeiro: Contraponto. Editora PUC-Rio, 2013.

CUTI. Literatura negro-brasileira. São Paulo: Selo Negro Edições, 2010.

Depoimento. In: DUARTE, Eduardo de Assis e FONSECA, Maria Nazareth Soares. Literatura e afrodescendência no Brasil: antologia crítica. Belo Horizonte: editora UFMG, 2011, v.4, p. 45-70.

Fundo de Quintal nas Umbigadas. In: I Encontro de Poetas e Ficcionistas Negros Brasileiros (org.). Criação Crioula, Nu Elefante Branco, São Paulo: Imesp, 1987.

DALCASTAGNÈ, Regina. Literatura brasileira contemporânea: um território contestado. Vinhedo, Editora Horizonte/ Rio de Janeiro, Editora da UERJ, 2012.

DERRIDA, Jacques. Gramatologia. Tradução Miriam Schnaiderman e Renato Janini Ribeiro. São Paulo, Perspectiva, Ed. da Universidade de São Paulo, 1973.

DUARTE, Eduardo de Assis. Por um conceito de literatura afro-brasileira. In: Literatura e afrodescendência no Brasil: antologia crítica. V. 4 - Belo Horizonte: Editora UFMG, 2011.

Literatura afro-brasileira: um conceito em construção. In: Estudos de literatura brasileira contemporânea, no $31-$ Brasília, janeiro/junho, 2008, pp. 11-22.

. Entre Orfeu e Exu, a afrodescendência toma a palavra. In: Literatura e afrodescendência no Brasil: antologia crítica (Precursores). Belo Horizonte: Editora UFMG, 1 v. - (Humanitas), 2011.

; FONSECA, Maria Nazareth Soares (Organizadores).

Literatura e afrodescendência no Brasil: antologia crítica. Belo Horizonte: Editora UFMG, 4 v. - (Humanitas), 2011.

EAGLETON, Terry. Teoria da literatura: Uma introdução. Tradução Waltersir Dutra: revisão João Azenha Jr. - 2a edição - São Paulo: Martins Fontes, 1994.

EVARISTO, Conceição. Poemas da recordação e outros movimentos. Belo Horizonte: Nandyala, 2008.

Becos da Memória. Florianópolis: Editora Mulheres, 2013.

Becos da Memória. Belo Horizonte: Mazza Edições, 2006.

Edições, 2003. Ponciá Vicêncio. - $1^{\text {a }}$ reimpressão - Belo Horizonte: Mazza 
Edições, 2005.

$$
\text { Ponciá Vicêncio. - } 2^{\mathrm{a}} \text { edição - Belo Horizonte: Mazza }
$$

"Literatura negra: uma voz quilombola na literatura brasileira" In: PEREIRA, Edmilson de Almeida (Org.). Um tigre na floresta de signos: estudos sobre a poesia e demandas sociais no Brasil. Belo Horizonte: Mazza, 2010, p.132-142.

Da grafia-desenho de minha mãe, um dos lugares de nascimento da minha escrita. In: ALEXANDRE, Marcos Antônio(Org.). Representações Performáticas brasileiras: teorias, práticas e interfaces. Belo Horizonte: Mazza Edições, 2007.

Depoimento. In: DUARTE, Eduardo de Assis e FONSECA, Maria Nazareth Soares. Literatura e afrodescendência no Brasil: antologia crítica. Belo Horizonte: editora UFMG, 2011, v.4, p.103-116.

Mineiridade. Eu-mulher. Os sonhos. Vozes-mulheres. Fluida lembrança. Negro-estrela. In: Cadernos Negros 13: poesia. São Paulo: Quilombhoje, 1990, p. 29-36.

Quilombhoje, 1991, p. 9-15.

Di Lixão. Maria. In: Cadernos Negros14: contos. São Paulo:

. "Recordar é preciso". Menina. Brincadeiras. Pão. Meu corpo igual. Favela. Filhos na rua. Pedra, pau, espinho e grade. Bus. Meu rosário. Stop. In: Cadernos Negros 15: poesia. São Paulo: Quilombhoje, 1992. p. 17-24.

Quilombhoje, 1993.p. 29-37.

Duzu-Querença. In: Cadernos Negros 16: contos. São Paulo:

Ana Davenga. In: Cadernos Negros 18: contos. São Paulo:

Quilombhoje, 1995. p. 17-26.

. Malungo, brother, irmão. A noite não adormece nos olhos das mulheres. A escrever... . In: Cadernos Negros 19: poesia. São Paulo: Quilombhoje, 1996. p. 23-27.

Todas as manhãs. Os bravos e serenos herdarão a terra. Para a menina. Se à noite fizer sol. M e M. Tantas são as estrelas... . In: Cadernos Negros 21: poesia. São Paulo: Quilombhoje, 1998. p. 32-39.

Quantos filhos Natalina teve?. In: Cadernos Negros 22: contos. São Paulo: Quilombhoje, 1999. p. 21-28.

.De mãe. Da velha à menina. Da menina, a pipa. Do menino, a bola. Da esperança, o homem. In: Cadernos Negros 25: poesia. Organizadores: RIBEIRO, Esmeralda e BARBOSA, Márcio. São Paulo: Quilombhoje, 2002. p. 36-43.

. Beijo na face. In: Cadernos Negros 26: contos. Organizadores: RIBEIRO, Esmeralda e BARBOSA, Márcio. São Paulo: Quilombhoje, 2003. p. 11-18. 
Olhos d'água. Ayoluwa, a alegria do nosso povo. In:

Cadernos Negros 28: contos. São Paulo: Quilombhoje, 2005. p. 29 -39

Zaita esqueceu de guardar os brinquedos. In: Cadernos

Negros 30: contos. Organizadores: RIBEIRO, Esmeralda e BARBOSA, Márcio. São Paulo: Quilombhoje, 2007. p. 35-42.

FERRETTI, Maria Cecília Galletti. $O$ infantil Lacan e a modernidade. Petrópolis- RJ: Vozes, 2004.

FREYRE, Gilberto. Casa-grande \& Senzala: formação da família brasileira sob o regime da economia patriarcal. 48 a edição. São Paulo: Global, 2003.

FOUCAULT, M. A Ordem do Discurso - Aula inaugural no College de France.Pronunciada em 2 de dezembro de 1970. São Paulo. Ed. Loyola: 1996.

GINZBURG, Jaime. Cânone e valor estético em uma teoria autoritária da literatura. In: Revista de Letras, nº 44(1) - São Paulo, 2004, pp. 97-111.

HALBWACHS, M. 1990. A memória coletiva. São Paulo: Centauro, 2006.

HALL, Stuart. A identidade cultural na pós-modernidade. Tradução de Thomas Tadeu da Silva e Guacira Lopes Louro. 11 ed. Rio de Janeiro: DP\&A, 2006.

IANNI, Octávio. Literatura e Consciência. Estudos Afro-Asiáticos, Rio de Janeiro, CEAA/Universidade Candido Mendes, n. 15, p.208-217, jun. 1988.

Literatura e consciência. In: Literatura e afrodescendência no Brasil: antologia crítica. V. 4 - Belo Horizonte: Editora UFMG, 2011.

JEHA, Julio. (1993) Mimese e mundos Possíveis. Revista Signótica, v. 5, n. 1. pp. 7990. Disponível em: http://www.revistas.ufg.br/index.php/sig/article/view/7354/5219 Acesso em 11 agosto 2013.

JESUS, Carolina Maria de. Quarto de despejo: diário de uma favelada. São Paulo: Ática, 2005.

KOHAN, Walter O. Infância, estrangeiridade e ignorância - ensaios de filosofia e educação. Belo Horizonte, Autêntica, 2007.

e KENNEDY, David (organizadores). Filosofia e infância: Possibilidades de um encontro. Petrópolis, RJ: Vozes, 1999. - (Série filosofia e criança; v. 3).

KRAMER, Sonia. "Infância, cultura contemporânea e educação contra a barbárie". In: BAZÍLIO, Luiz Cavalieri; KRAMER, Sonia. Infância, educação e direitos humanos. São Paulo: Cortez, 2003, pp. 83-106.

KRISTEVA, Julia. Estrangeiros para nós mesmos. Trad. Maria Carlota C. Gomes. Rio de Janeiro: Rocco, 1994. 
LOBO, Luiza Leite Bruno. Crítica sem juízo. $2^{\text {a }}$ Rio de Janeiro: Garamond, Ed. Revista, 2007.

MARTIN, Charles. Uma rara visão de liberdade. In: REIS, Maria Firmino dos. Úrsula. $3^{\text {a }}$ edição. Rio de Janeiro: Presença Edições, 1988.

MATA, Anderson Luís Nunes da. O silêncio das crianças: representação da infância na narrativa brasileira contemporânea. Londrina: EDUEL, 2010.

MELLO, Marilene Carlos do Vale. A figura do griot e a relação memória e narrativa. In: LIMA, Tânia; NASCIMENTO, Izabel; OLIVEIRA, Andrey (organizadores). Griotculturas africanas: linguagem, memória e imaginário. - 1. ed. - Natal: Lucgraf, 2009.

MIGNOLO, Walter D. Histórias locais/Projetos globais: colonialidade, saberes subalternos e pensamento liminar. Tradução Solange Ribeiro de Oliveira. Belo Horizonte: Editora UFMG, 2003.

NUNES, Ferreira Brasilmar. Sociedade e Infância no Brasil. Brasília: Editora Universidade de Brasília, 2003.

NUNES, Marcelo Costa e ALVES, Rafael. Oyé Orixá: Umbanda e a síntese dos princípios do branco, do vermelho e do negro. $1^{\text {a }}$ edição. Brasília: Casas da Musas, 2009.

PEREIRA, Edimilson de Almeida. Zeozório Blues: obra poética 1. Belo Horizonte: Mazza Edições, 2002.

PEREIRA, Edimilson de Almeida (1995). Panorama da literatura afro-brasileira. Disponível:http://www.letras.ufmg.br/literafro/data1/artigos/artigoedmilsoncallaloo.pdf. Acesso em 29 agosto 2014.

PITKIN, Hanna Fenichel. El concepto de representación. Tradução de Ricardo Montoro Romero. Madrid: Centro de Estudios constitucionales, 1985.

PINTO, Manuel. A infância como construção social. In: PINTO, M. e SARMENTO, M. A crianças, contextos e identidades. CEI, Minho, 1997.

PRADO, Dirce Pereira do. A infância de Daiane. In: Cadernos Negros. Volume 32: contos afro-brasileiros/ Organizadores RIBEIRO, Esmeralda; BARBOSA, Márcio. São Paulo: Quilombhoje, 2009.

ROUSSEAU, Jean-Jacques. Emílio, ou da Educação. Tradução: Tradução: Sérgio Millet. Rio de Janeiro: Bertrand, 1995.

SCHMIDT, Rita Terezinha. Cânone e contra-cânone: nem aquele que é o mesmo e nem este que é Outro. In: $O$ discurso crítico na América Latina. CARVALHAL, Tânia Franco . Porto Alegre: IEL/ED. Unisinos, pp. 115- 121, 1996.

SHOHAT, Ella; STAM, Robert. Critica da imagem eurocêntrica: multiculturalismo e Representação. trad. Mário Soares. São Paulo: Cosac e Naify, 2004. 
SILVA, Assunção de Maria Sousa. "Ponciá Vicêncio, memórias do eu rasurado". In: DEALTRY, G.; LEMOS, M.; CHIARELLI, S. (Org.). Alguma prosa ensaios sobre literatura brasileira contemporânea. Rio de Janeiro: 7 Letras, p. 73-83, 2007.

SOUZA, Cruz e. Cruz e Souza obras completas. Organização e estudos: Lauro Junkes. Vol. I - Jaraguá do Sul: Avenida; 2008.

FONSECA, Maria Nazareth Soares. Literatura Negra Literatura Afro-brasileira: como responder à polêmica? In: SOUZA, Florentina; LIMA, Maria Nazaré (Organizadoras). Literatura afro-brasileira. Salvador: Centro de Estudos Afro-Orientais; Brasília: Fundação Cultural Palmares, 2006.

SPIVAK, Gayatri Chakravorty. Pode o subalterno falar. Tadução de Sandra Regina Goulart Almeida, Marcos Pereira Feitosa, André Pereira Feitosa. Belo Horizonte: Editora UFMG, 2010.

STAROBINSKY, Jean. Jean-Jacques Rousseau: a transparência e o Obstáculo; seguido de sete ensaios sobre Rousseau. São Paulo: Companhia das Letras, 1991.

TRINDADE, Solano. O poeta do povo. São Paulo. Ediouro : Editora Segmento Farma, 2008 .

WOOLF, Virgínia. Um teto todo seu. 2. ed. Rio de Janeiro: Nova Fronteira, 2004.

VERGER, Pierre. Orixás. São Paulo: Círculo do Livro/Corrupio, 1986. 